\title{
UNA VISITA DE KELSEN *
}

\author{
Jesús Vega \\ Universidad de Alicante
}

RESUMEN. Se investiga en este trabajo la única visita que Hans KeLSEN hizo a España a lo largo de su vida. Esta visita fue a Granada, en 1956, para asistir a una reunión del Institut de Droit International. La Universidad de Salamanca había nombrado a KELSEN doctor honoris causa, junto con otros juristas, en 1954, con ocasión de su VII Centenario. En ese acto se había otorgado también la misma distinción a Francisco Franco, Jefe del Estado español. KELSEN no acudió al acto de investidura. Cuando dos años después visita Granada se interesa, sin embargo, por obtener el diploma acreditativo dirigiéndose por carta a la Universidad de Salamanca. Esta carta se publica al final del presente trabajo. El objeto del mismo es averiguar la conexión que existió entre estos acontecimientos: por qué KELSEN no acudió a Salamanca para ser investido como doctor honoris causa en 1954 y por qué reivindicó este título en 1956 en su visita a Granada. Para ello, el trabajo considera tanto el contexto histórico-político de las relaciones España-Estados Unidos en ese momento, como también el contexto biográfico de KELSEN.

Palabras clave: Hans KELSEN, biografía, España, franquismo, Institut de Droit International, Granada, VII Centenario de la Universidad de Salamanca, doctor honoris causa, Berkeley, anticomunismo, positivismo jurídico.

\section{A Visit by Kelsen}

ABSTRACT. This paper investigates the only visit to Spain Hans KELSEN made throughout his life. This was to Granada in 1956, to attend a meeting of the Institut de Droit International. The University of Salamanca had appointed KELSEN honorary doctor KELSEN, along with other jurists in 1954, celebrating its seventh centenary. On the event was also awarded the same distinction to Francisco Franco, Head of the Spanish State. KELSEN excused attendance at the investiture ceremony. Two years later, during his visit to Granada, he was interested nevertheless in obtaining the diploma and addressed a letter to the University of Salamanca to that effect. This letter is published at the end of this paper. The purpose of the latter is to find out the connection that existed between these events: why KELSEN did not go to Salamanca to collect his honorary doctorate in 1954 and why he claimed it in 1956 during his visit to Granada. For that purpose, the paper takes into consideration both the historical-polítical context of the Spain-EEUU relations and the biographical context of KELSEN.

Keywords: Hans KeLSEN, biography, Spain, Franquism, Institut de Droit International, Granada, VII Centenary of Salamanca University, doctor honoris causa, Berkeley, anticommunism, legal positivism.

* Fecha de recepción: 7 de septiembre de 2015. Fecha de aceptación: 22 de septiembre de 2015.

Este trabajo se enmarca en el Proyecto de Investigación Desarrollo de una concepción argumentativa del Derecho (DER2013-42472-P), financiado por el Ministerio de Economía y Competitividad. 


\section{INTRODUCCIÓN}

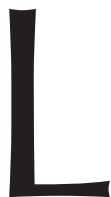

as páginas que siguen tienen por objeto dar noticia de cierta pequeña pero intrincada historia que seguramente resulte desconocida —me atrevería a decir - para muchos de los iusfilósofos de nuestro país, aunque tal vez no tanto para otros colegas del gremio jurídico, como los internacionalistas o los historiadores del derecho. Una historia cuyos hechos tienen que ver con la presencia en España de Hans KELSEN, el eminente teórico del derecho. Su presencia real y efectiva, en persona, quiero decir: no ya su presencia doctrinal, que es ubicua, paradójica y epidérmica a partes iguales, como bien sabemos.

Solía darse por sobreentendido entre nosotros que el autor de la gran Teoría pura del Derecho y quien fuera calificado célebremente como «el jurista de la época» nunca había tenido la oportunidad de visitar nuestro país, a diferencia de otros grandes iusfilósofos como HART o DWORKIN. Y sin embargo esa suposición es equivocada: KELSEN sí que visitó España en una ocasión, en concreto la ciudad de Granada durante unos breves días en abril de 1956 para tomar parte en la XLVII Reunión del Institut de Droit International allí celebrada ${ }^{1}$.

Debo evocar aquí una ocasión en la que yo mismo pude comprobar cómo ese sobreentendido afloraba de nuevo. Se trataba de una charla de sobremesa en el marco de cierta reunión académica celebrada hace algún tiempo y en la cual se encuentra la causa biográfica inmediata de la redacción de estas líneas, razón por la cual la traigo aquí. En aquella circunstancia — hablo de un congreso internacional- Manuel ATIENZA debía intervenir en la sesión vespertina con una ponencia sobre «Kelsen and Hart in 20th-century Legal Philosophy in Spanish-speaking Countries». No recuerdo bien si fue éste o Francisco LAPORTA, también presente, quien comentando al respecto redundó en la observación acerca de la lamentada ausencia de KELSEN de tierras españolas —que no hispánicas, pues eran conocidos sus viajes a Latinoamérica: Argentina, México, Brasil, Uruguay y hasta Cuba-, ausencia que contrastaba, por ejemplo, con la legendaria conferencia que HART había dictado en la Universidad Autónoma de Madrid en 1979, en donde anticipaba en quince años las tesis del Postscriptum, etcétera.

Yo di entonces por descontada la verdad de aquel comentario. Pero ello no impidió que viniera a mi mente la noción, nebulosa pero tenaz, de que KELSEN en realidad sí que habría venido al menos en una ocasión a España, siquiera de forma fugaz. Así lo manifesté ante mis contertulios, no sin titubeo, queriendo recordar vagamente que la visita se habría producido con ocasión de algún evento académico (¿tal vez una tesis doctoral?) y que así pude haberlo escuchado en alguna ocasión de algún colega solventemente informado (¿tal vez José DELGADO PINTO en una de sus visitas a la Universidad de Oviedo?). Ante las dudas, ajenas y propias, recuerdo que, aprovechando la tecnología a la mano, hice una rápida búsqueda en internet («Kelsen en España»), que me llevó de inmediato a diversos textos sobre el tópico, en ninguno de los cuales hallé sin embargo la ansiada corroboración del dato. De manera que tuve que conformarme

1 En realidad, KELSEN estuvo dos veces en España, aunque la primera de ellas — como se verá— difícilmente puede ser calificada de «visita». 
con anotar mentalmente la tarea pendiente de certificar en algún otro momento su verdad o falsedad.

La cosa no hubiera pasado de ahí — de morir en el limbo de las curiosidades pendientes - si a ese dato no se hubieran anudado posteriormente otros que, como pasa siempre con los datos, lo volvieron significativo. El «contexto de descubrimiento» de aquella conversación de sobremesa me condujo, en efecto, al «contexto de justificación» gracias a otros hechos que pude averiguar a continuación y cuya conjunción revestía de un inesperado sentido y, ahora sí, de un interés mucho mayor que el de una simple corroboración empírica a la hipotética visita española de KELSEN. En intercambio por correo electrónico en las semanas posteriores con la profesora Lourdes SANTOS de la Universidad de Salamanca pude contrastar no sólo lo verídico de mi borrosa intuición sino también que su fuente había sido efectivamente el profesor DELGADO PINTO, catedrático de Filosofía del Derecho de esa Universidad y precisamente uno de los mejores conocedores — junto con su también discípulo Miguel Ángel RoDILLAde la obra kelseniana. Pero esa nueva información iba a contar, para mi sorpresa, con una inesperada ampliación. Pues ahora resultaba que las ciudades de Granada y de Salamanca quedaban puestas en conexión, no a través de un vago recuerdo mío relativo a KELSEN, sino a través de KELSEN mismo.

Los hechos en cuestión, cuya concatenación tejía ese nuevo contexto de sentido completamente imprevisto, eran, para exponerlos desde el principio, los siguientes:

1. ${ }^{\circ}$ A KELSEN le había sido otorgado el Doctorado bonoris causa por la Universidad de Salamanca, junto con otros profesores, tras ser propuesto por la Facultad de Derecho en 1954.

2. ${ }^{\circ}$ Esa universidad había propuesto conceder igualmente, en 1948, el Doctorado honoris causa a Francisco FRANCO, Jefe del Estado español, en reconocimiento de sus méritos como Generalísimo y Caudillo de España vencedor de la guerra civil.

3. ${ }^{\circ}$ El acto de investidura se celebró en 1954, coincidiendo con el VII Centenario de la Universidad salmantina.

4..$^{\circ}$ KeLSEN no acudió al acto de investidura doctoral.

5..$^{\circ}$ Dos años más tarde, en 1956, KELSEN visita Granada.

6. $\left.^{\circ}\right)$ Se interesa desde allí por el diploma de doctorado bonoris causa y por su pertenencia efectiva al claustro de la Universidad de Salamanca, poniéndose a tal efecto en contacto con ésta por escrito.

Puestos al tanto de lo inédito y chocante de estos hechos, los dos interlocutores de la conversación antes mencionada consideraron que sin duda merecían ser investigados a fondo y su relato dado a conocer. El propio ATIENZA sugirió que «Una visita de Kelsen» sería un buen título. Lo que sigue es, pues, el resultado de mi indagación de esa visita y su circunstancia.

Una indagación que resultó ser finalmente mucho más que una simple «narración fáctica». De un lado, porque los hechos fundamentales sobre los que versa son «hechos negativos», es decir, omisiones. Fundamentalmente: ¿por qué no vino KELSEN a Salamanca? ¿por qué no rechazó el doctorado bonoris causa otorgado por el franquismo? Las evidencias al respecto eran además inexistentes o fragmentarias. La investigación requería, pues, reconstrucción. De otro lado, la explicación de esos 
hechos (la «circunstancia»), necesaria para su comprensión y correcto juicio, involucraba contextos tan heterogéneos como la oscura España del primer franquismo y la última etapa académica y vital de KELSEN en Estados Unidos. Requería también, pues, interpretación.

He intentado ajustarme en todo momento a datos objetivos eludiendo en lo posible la especulación, aunque advierto desde el principio que ésta no ha podido eliminarse del todo. También he tratado de resistir la tentación de ser más amigo de Platón que de la verdad. Mi propósito, de cualquier modo, no ha sido tanto hacer una investigación historiográfica (para lo cual disto de estar capacitado) cuanto rendir un homenaje a la figura de KELSEN y a su trayectoria vital en una época, esa que le tocó vivir, sin la menor duda mucho más difícil y tormentosa que la nuestra.

\section{KELSEN EN GRANADA: LA REUNIÓN DEL INSTITUT DE DROIT INTERNATIONAL}

En una amable carta, que aprovecho ahora para agradecer públicamente, el profesor José Delgado PiNTO me informó con exactitud —-documentación incluida- de lo fundamental acerca de las circunstancias del nombramiento de KELSEN como doctor bonoris causa por la Universidad de Salamanca, circunstancias que enseguida detallaré. El dato de la visita de KELSEN a España pude corroborarlo ya en la biografía de Rudolf A. MÉTAll donde consta expresamente la cita de Granada ${ }^{2}$. Pero Delgado PinTo me lo confirmó además en primera persona: el jurista vienés habría estado en Granada en la primavera de 1956 «en un congreso (creo que de derecho internacional)», de cuya celebración «no dispongo de documentación» pero sí un «vago recuerdo», puesto que «entonces yo trabajaba allí en mi tesis doctoral».

La averiguación sobre este congreso me llevó a descubrir que se trataba en realidad de la XLVII Reunión del Institut de Droit International que tuvo lugar en Granada del 11 al 20 de abril de 1956. Precisamente el Director de tesis de DELGADO PINTO era Luis Sánchez Agesta, quien ocupa un lugar en nuestro relato por dos razones. Primero, era catedrático de lo que entonces se llamaba «Derecho político» (la tesis de Delgado versaba sobre el concepto de «leyes fundamentales» y su relación con

2 Métall, 1976: 92. Como se sabe, MÉTAll fue discípulo y amigo de KELSEN. Esta semblanza biográfica, que es la más conocida, es de suponer que cuenta por consiguiente con su aprobación. Pero el mismo KELSEN escribió dos piezas autobiográficas: una Autopresentación (Selbstdarstellung) —-muy breve y de carácter más doctrinal que personal, firmada en Viena en 1927- y una Autobiographie escrita veinte años después, en 1947, ya en Berkeley, cuando KELSEN veía el fin de su carrera universitaria en Estados Unidos y que MÉTALL reproduce en más de dos terceras partes. Ambos escritos estaban inéditos y no fueron dados a conocer hasta 2006 . El 11 de octubre de ese año, conmemorando el $125 .^{\circ}$ aniversario de su nacimiento, ambos se editaron en un volumen especial presentado en el parlamento austriaco coincidiendo con el anuncio del proyecto de una edición crítica de sus obras completas en treinta volúmenes en colaboración con el Hans Kelsen-Institut. Cfr. JESTAEDT (ed.) (2006). El primer volumen de esas obras completas, aparecido el año siguiente, incluye las dos autobiografías junto con los primeros escritos de KELSEN publicados entre 1905 y 1910. Cfr. KELSEN, 2007. Las dos reseñas autobiográficas, con la introducción y notas críticas de JESTAEDT, han sido traducidas al español por L. VILLAR BORDA: KELSEN, 2008. Otras aproximaciones biográficas de las que he hecho uso en este trabajo son: NITSCH, 2009: Olechowski, 2011; García-SAlmones, 2013, Cap. 5; LOSANO, 2006; LADAVAC, 1998; EHS/GASSNER, 2015; SCHAMBECK, 2013; ROBLES, 2014. 
el de constitución) ${ }^{3}$ y un reconocido erudito: tenía que ser, por tanto, conocedor de la obra de KELSEN. Segundo, era a la sazón el Rector de la Universidad de Granada (desde 1951 hasta 1960) y en su condición de tal (había sido nombrado por otro protagonista de nuestra historia de quien luego hablaremos: el ministro de Educación Joaquín RuIZ GIMÉNEZ) presidió la Comisión organizadora de la reunión del Institut de Droit International e intervino de manera principal en su solemne sesión inaugural y en su desarrollo, que tuvo lugar en la propia Universidad. Ambas razones corroboran efectivamente que DELGADO PINTO debió de tener conocimiento directo del evento y de la presencia de KELSEN en Granada. Sólo su juventud (tenía veinticuatro años) y, por supuesto, la distancia en el tiempo (han pasado casi sesenta años desde entonces) permiten explicar tal vez la vaguedad del recuerdo. Nada le habría impedido estar presente en aquella sesión inaugural —a la que sabemos asistió todo el profesorado de la Facultad de Derecho- y conocer en persona al autor que años después habría de estudiar tan a fondo ${ }^{4}$. Pero es obvio que también ha de formar parte central de la explicación del olvido la condenación académica que la figura de KELSEN sufrió en la España de aquellos años: una figura, recordemos, ya consagrada desde los tiempos de la República como cimero representante de la tradición del derecho público alemán ${ }^{5}$, muy significado desde el punto de vista doctrinal e ideológico en pro de la democracia liberal y, por ello, proscrito en el primer franquismo. Que KELSEN fuera rabiosamente condenado y al mismo tiempo honoríficamente distinguido en Salamanca y Granada nos introduce de lleno en las contradicciones de nuestra historia necesitadas de interpretación. En cualquier caso, como también comprobaremos, hay razones para pensar que el paso de KELSEN por Granada fue bastante breve y que no permaneció en la ciudad durante todas las sesiones de la reunión. Pero vayamos a la reunión misma.

Como se sabe, el Institut de Droit International es una entidad muy similar en formato y función a la Academia de Derecho Internacional de La Haya. Fue fundada por un grupo de juristas en 1873 en la ciudad belga de Gante como sociedad científica de carácter no gubernamental bajo el designio de promover el desarrollo del derecho internacional, según una máxima que con el tiempo sería desde luego divisa kelseniana: la paz a través del derecho. Celebra encuentros bianuales de forma prácticamente ininterrumpida desde entonces (con el elocuente lapso de las dos guerras) siguiendo la práctica itinerante de no vincularse a ninguna ciudad o país a fin de mantener su independencia.

La reunión de Granada, en la que se dieron cita 67 miembros (de un total de 117), procedentes de los cinco continentes, aunque con un claro predominio europeo, fue presidida por el español José María YanguAs Messía, catedrático de derecho internacional de la Universidad Central de Madrid, antiguo ministro de Estado durante la dictadura de Primo de Rivera y presidente del Instituto entre 1954 y 1956. Como

3 RODILLA, 2002: 737-738. SÁNCHEZ AgESTA fue el principal representante de lo que, con clamoroso oxímoron, se ha querido llamar el «constitucionalismo franquista» y fautor de la Ley Orgánica del Estado de 1967.

4 En 1958 pasaría Delgado PINTO a ser profesor adjunto de Derecho Natural y Filosofía del Derecho (RoDILLA, 2002: 738).

5 Cfr. Sosa Wagner, 2004: 151 y ss. Ahí figuraban además nombres como los de LABAND, JELLINEK, MAYER, Heller, SCHMitT, TRIEPEL, etc. Es sabido que fue fundamental el papel de la Junta para la Ampliación de Estudios pensionando a los más talentosos de entre los jóvenes juristas españoles para formarse en Alemania. Vid. SOSA WAGNER, 2009 y 2002: 146 y ss. 
Presidente honorario actuó Ch. DE VISSCHER, ex juez del Tribunal Internacional de Justicia de La Haya. Con pocas excepciones, la mayoría de los asistentes eran juristas y profesores, miembros de tribunales internacionales y altos tribunales nacionales, abogados y asesores gubernamentales. En total pertenecían a 36 países y entre sus nombres destacados figuraban los de A. VERDROSS (quien también reaparecerá en nuestro guión), H. Batiffol, P. Guggenheim, J. Basdevant, R. Ago,... Cabe destacar que Alf Ross, el iusfilósofo realista y también discípulo de KELSEN, era asimismo miembro asociado del Instituto (a título de «Professeur de Droit Public et de Philosophie de Droit»), aunque no estuvo presente en la sesión de Granada. KELSEN era miembro honorario del Instituto. Había sido nombrado en la reunión anterior de 1954 (celebrada en Aix-en-Provence) a propuesta de VERDROss. Representaba a los Estados Unidos.

El congreso fue, sin duda, un evento de primera importancia tanto para la ciudad de Granada como para su universidad. También lo fue para el régimen de FrAnCO, dada la coyuntura política internacional de España, como tendremos ocasión de ver. Indicio de tal importancia fue la gran repercusión que la reunión del Institut tuvo en la prensa de la época. El periódico entonces más influyente del país, el $A B C$ de Madrid, siguió el desarrollo del encuentro prácticamente a diario, desde su inauguración hasta su clausura, reseñando con sorprendente despliegue de pormenores el transcurso de las sesiones y el contenido de las ponencias y debates, así como sus protagonistas y los actos sociales del congreso. Esta información periodística, junto con la crónica de la reunión que uno de sus miembros redactó para la American Journal of International Law ese mismo año y los pocos datos que sobre ella constan en el Anuario editado por el Instituto, constituyen de hecho las fuentes casi exclusivas de donde he podido extraer los datos aquí narrados ${ }^{6}$. Por increíble que parezca, en el archivo de la Universidad de Granada no obra información alguna, ni documental ni gráfica, relativa a la reunión del Instituto de Derecho Internacional. Algo bastante insólito, teniendo en cuenta que, como ya se dijo, la sesión inaugural de la reunión tuvo lugar en solemne ceremonia oficiada en el paraninfo de la Universidad, el 11 de abril, en presencia del Rector, y las ocho jornadas de la reunión tuvieron lugar en las propias aulas de la Universidad ${ }^{7}$.

A la ceremonia de apertura acudieron las autoridades políticas, militares y eclesiásticas. En su discurso inaugural, el Presidente del Instituto - YANGUAS MESSíA—no perdió la ocasión, como era predecible, para remontarse a la autoridad de la escolástica clásica española, particularmente además en la persona de un ilustre granadino: Francisco SuÁREZ. YANGUAS pudo encontrar en la obra de éste hilos bastantes para enhebrar de una sola puntada la ciudad de Granada, el Institut de Droit International, la escuela hispánica del derecho de gentes y la situación internacional coetánea de España: para ello venían como anillo al dedo los pasajes 17 al 20 del De Legibus relativos al ius gentium. Conservamos el discurso íntegro gracias a la publicación de las actas de la reunión en el Annuaire ${ }^{8}$. Pero interesa transcribir cómo fue reproducido en la prensa de la época, pues ello ofrece buena muestra de hasta qué punto el significado

\footnotetext{
6 Cfr. FINCH, 1956: 640-647. También puede verse una pequeña reseña en SCHÄTZEL,1956. Vid. también el Annuaire de L'Institut de Droit international, vol. 46: Session de Grenade, Avril 1956 (Bale, Editions Juridiques et Sociologiques S.A., 1956).

7 Annuaire, op. cit., 75; $A B C, 13$ abril de 1956.

8 Annuaire, op. cit., 99-106.
} 
de la reunión trascendía efectivamente mucho más allá de la ciudad de Granada. La crónica del diario $A B C$ resumía con profusión y exactitud el discurso de YANGUAS en los siguientes términos:

Todavía en los comienzos del siglo XVII, anticipándose en tres siglos a nuestro tiempo, el gran teólogo y jurista granadino supo fijar con acierto insuperable la naturaleza y los principios del derecho de gentes y de la sociedad internacional. Su doctrina es una admirable síntesis de la doctrina clásica española fundada en el siglo XVI en su cátedra de Salamanca por Francisco de Vitoria y en la que, a lo largo de los siglos, brillaron nombres como los de Vázquez de Menchaca, Soto, Molina, Báñez, Lorca y tantos otros. «Ningún Estado se basta a sí mismo ni puede prescindir en algún grado de la asistencia mutua, de la asociación y del intercambio con los demás; unas veces, para obtener más ventajas y bienestar; otras, por padecer una verdadera indigencia moral, como lo comprueba la experiencia». Palabras éstas de Suárez que, no obstante su lejanía en el tiempo, son de tan gran actualidad en el mundo en que vivimos. «Para conducirse y gobernarse con rectitud en esta especie de asociación, los Estados tienen necesidad de un cierto derecho que la razón natural aconseja y la costumbre de las naciones ha introducido en su vida de relación». Así nace el Derecho Internacional. Imagen de esta universalidad es el propio Instituto reunido en Granada. Compuesto de juristas originarios de todos los continentes, este Instituto refleja la diversidad de razas, de religiones y de culturas. Pero a todos les liga un vínculo común: su vocación por el Derecho y su amor por la justicia. Órgano de la conciencia jurídica del mundo civilizado, el Instituto no es ni una academia especulativa ni una conferencia diplomática. Asociación exclusivamente científica y sin carácter oficial, no cultiva una ciencia puramente teórica; formula principios y redacta proyectos susceptibles de ser acogidos en convenios internacionales, en las leyes internas de los Estados, o en las sentencias de los árbitros y de los jueces. El Instituto de Derecho Internacional persigue así, como perseguía Suárez, el equilibrio entre lo ideal y lo real, entre la razón que exige y la voluntad que consiente, entre la justicia objetiva permanente y el derecho histórico y variable aceptado por los Estados?

No había presencia de autoridades gubernamentales (no era procedente quizá dada la neutralidad política del Institut), pero resulta evidente que la celebración de la reunión en Granada estaba siendo utilizada políticamente en el marco de la estrategia de integración internacional del régimen franquista emprendida por aquellos años. Un régimen que acababa de conseguir el levantamiento de la condena internacional y el ingreso en la ONU de España. El suareciano «ningún Estado se basta a sí mismo» (Leg., II, 19, 5) reflejaba perfectamente el rumbo de la rectificación de la política autárquica de posguerra, a 20 años del final de la contienda civil, aunque aún tardarían bastante tiempo en cambiar las cosas dentro del país.

No sabemos cómo pudo resonar a oídos de KELSEN, allí presente, esa inflamada invocación del fundamento iusnaturalista del derecho internacional hecha por el discurso de YANGUAS, adornada además de tal modo con la idea escolástica de «ciencia práctica», pero es fácil de imaginar: como una doble contradictio in adiecto. De lo que sí podemos dar noticia parcialmente es de su intervención en la reunión. El citado Annuaire de 1956 contiene la transcripción de las deliberaciones de todas y cada una de las sesiones así como las actas de las votaciones de las propuestas finales, donde los votos figuran nominatim. Ahí comprobamos que KELSEN no intervino ni una sola vez

9 «Ningún Estado se basta a sí mismo ni puede prescindir de la asociación con los demás. Discurso de D. José de YANGUAS MESSíA en la apertura de la XLVII Reunión del Instituto de Derecho Internacional», $A B C$, jueves 12 de abril de 1956, 34 . 
en los debates de las ponencias y que solamente emitió un voto (positivo) en la primera de las propuestas (que versaba sobre un asunto de derecho internacional privado). No estuvo presente en las seis últimas sesiones (que discutían cuestiones mucho más cercanas a temas estudiados por él, como la jurisdicción obligatoria del TIJ, la regla de agotamiento de los recursos internos o la interpretación de los tratados) ni tampoco asistió a la jornada de clausura ${ }^{10}$. Su presencia en la reunión parece que fue, pues, más bien simbólica o testimonial, quizá como correspondía a su condición de miembro honorario. Lo más probable es que abandonara Granada después del 16 de abril.

Tal vez por ello el día anterior, domingo 15, se publicó una entrevista suya en el diario $A B C$, que días atrás venía recabando también la opinión de otros egregios congresistas (YANGUAS, DE VISSCHER, BASDEVANT). Bajo un titular que anunciaba «Continúa sus tareas en Granada el Instituto de Derecho Internacional», el subtítulo añadía: «KELSEN opina que los Estados, como miembros de las Naciones Unidas, han perdido parte de su soberanía». En el cuerpo de la entrevista se le presentaba como «tratadista jurídico de renombre mundial y fundador de la llamada escuela de Viena. Austríaco de nacimiento, es en la actualidad súbdito de los Estados Unidos, en cuya Universidad de Berkeley (California) explica Jurisprudencia y Derecho Internacional». A continuación se transcribían estas declaraciones suyas:

[S]i por "soberanía" se entiende una ilimitada libertad de acción, los Estados como miembros de las Naciones Unidas han perdido, ciertamente, parte de su soberanía. La Carta les impone la obligación de refrenar en sus relaciones internacionales el uso de la fuerza, excepto en su autodefensa, y de arreglar sus conflictos solamente por medios pacíficos. La Organización de las Naciones Unidas es, por su propia naturaleza, una organización superestatal, pero no es un "superestado". En cuanto a la licitud de una guerra atómica, su criterio es que está ciertamente prohibida como guerra agresiva por la Carta de la ONU. Probablemente está también prohibida por el derecho general internacional en cuanto sus efectos destructores no puedan ser restringidos a los combatientes de las potencias beligerantes, sino que inevitablemente se extenderían a la población civil. Una prohibición general de las armas atómicas por convenio internacional es altamente deseable, si bien bajo las actuales circunstancias políticas del mundo tal acuerdo parece dudoso. Referente a una legislación internacional para la protección de los derechos humanos, el profesor KELSEN estima que es técnicamente posible. Pero ello sería efectivo solamente si el individuo cuyos derechos han sido violados por una acción de su Estado puede invocar a un Tribunal Internacional competente para abolir el acto ilegal de tal Estado. Esto supone una restricción de soberanía que la mayor parte de los gobiernos existentes probablemente no aceptarían. El ilustre miembro de honor del Instituto tampoco cree que pueda llevarse a la práctica en la hora presente el establecimiento de un Tribunal internacional con jurisdicción y medios coactivos apropiados para el mantenimiento de la paz en el mundo ${ }^{11}$.

Conocemos también algunos de los actos sociales a los que KELSEN, junto con los demás congresistas, asistió durante su estancia en Granada ${ }^{12}$. E incluso, aparte de su

10 Cfr. Annuaire, op. cit., 81 y ss., 124 y ss., 176 y ss., 265 y ss., 317 y ss., 355.

11 ABC, 15 de abril de 1956, 78.

12 No me resisto a transcribir la narración que FINCH hace de la parte lúdica del evento: «El programa social para la ocasión fue amable y generosamente organizado por los anfitriones españoles. Muchos de los miembros y asociados estaban acompañados por sus esposas, y algunos vinieron con sus hijos. Entre las sesiones de trabajo de los hombres se cursaron visitas a los famosos monumentos de Granada, cristianos y árabes, y una excursión dominical dio a los miembros y asociados la oportunidad de conocer la costa mediterránea con sus familias. El Presidente del Instituto y el Alcalde de Granada, con sus encantadoras esposas, recibieron y agasaja- 
pequeño itinerario turístico español y de los productos culturales patrios de que pudo disfrutar, sabemos de un inesperado suceso que debió de volver algo agitada la parte final del congreso y la visita de KELSEN a Granada (si es que aún permanecía allí). El día anterior a la clausura, el 19 de abril, se produjo un fuerte terremoto — de los más graves del siglo XX en España- que arrasó algunas localidades próximas a Granada y afectó muy seriamente algunos barrios de la ciudad, causando un total de 13 muertos y 73 heridos $^{13}$. Tal fue la gravedad del seísmo que el propio FRANCO visitó las zonas dañadas unos pocos días después (el 2 de mayo), como se da cuenta ampliamente en la prensa de la época.

De manera que el azar quiso que por muy poco no llegaran a cruzarse KELSEN y FRANCO en persona. De haberse prolongado unos días más aquella reunión de Granada tal vez tan prestigiosa comisión internacional, pese a su carácter «no oficial», no habría podido evitar un encuentro con el Jefe del Estado. De cualquier modo, contrafácticos aparte, lo cierto es que la trayectoria vital de KELSEN ya se había cruzado antes, virtual pero no por ello menos efectivamente, con la de FRANCO: ambos habían sido galardonados con el doctorado honoris causa por la Universidad de Salamanca. KELSEN, sin embargo, desistió de acudir a la ceremonia. ¿Por qué lo hizo? ¿Tuvo ello algo que ver con el hecho de que FRANCO fuera investido con el mismo honor académico en la misma ceremonia? Antes de ensayar cualquier respuesta a estas preguntas debemos recabar datos sobre ese otro solemne acto que involucró a KELSEN con España. Recorramos para ello los pasos que KELSEN dio, él mismo, en dirección a Salamanca.

\section{DE GRANADA A SALAMANCA}

En efecto, sabemos que durante su estancia en Granada KELSEN llevó a cabo gestiones ante el Secretario General de la Universidad, A. MESA-MoLES, para que éste

ron a todo el grupo en recepciones vespertinas en sus bellas residencias privadas; el Alcalde ofreció también un almuerzo en la biblioteca de la Universidad; el municipio dio un almuerzo en los jardines de verano del Palacio de la Alhambra; y el gobierno provincial [Provincial Council] obsequió a los invitados con un colorido festival regional en un enclave histórico. El Rector de la Universidad organizó un almuerzo en los salones del rectorado y también un concierto nocturno de música española en el gran salón de actos de la Facultad de Medicina a cargo de la consumada pianista Alicia de Larrocha. El Instituto correspondió a todas estas cortesías ofreciendo un banquete a sus anfitriones españoles en el Hotel Alhambra Palace la noche del 18 de abril» (FINCH, 1956: 644). En las notas de prensa y en la presentación del Annuaire que hace el secretario WEHBERG podemos contrastar que las rápidas visitas a los monumentos entre las sesiones de mañana y tarde, el almuerzo en la biblioteca universitaria (una «copa de Jerez» ofrecida por el Rector SÁNCHEZ AGESTA, según WEHBERG), las recepciones privadas y el concierto tuvieron lugar entre el jueves 12 y el sábado 14; que la pianista ejecutó piezas de ALBÉNIZ, FAlla, Granados y Turina; que la excursión mediterránea fue el domingo 15 de abril a Motril, Almuñécar «y alguna otra localidad de la costa del sol granadina»; que los jardines de verano eran en realidad los del Generalife (martes 17); y que el «colorido festival regional» tras la cena organizada por el Instituto como colofón del congreso la noche del miércoles 18 fue una «fiesta andaluza» («la soirée de danses espagnoles et gitanes», dice Wehberg) en la Casa de los Tiros. (A estos dos últimos eventos, como hemos apuntado, es muy posible que KELSEN no acudiera ya). La cena de clausura fue presidida por YANGUAS MESSÍA, quien hizo una emocionada exaltación de la ciudad de Granada recordando su historia árabe y cristiana «para confirmar que es una realidad el título de la película Todo es posible en Granada». También «manifestó que el Instituto de Derecho Internacional es una gran familia» (ABC, 15 y 19 de abril de 1956). Cfr. SCHÄTZEL, 1956: 63; Annuaire, cit., V.

13 El acta de la sesión de clausura refleja la alusión del presidente YANGUAS a que el encuentro de Granada terminó felizmente «malgré la réalisation de diverses manifestations météreologiques et sismiques» (Annuaire, op. cit., 356). 
contactara a su vez con el Secretario de la Universidad de Salamanca, M. GARCíA BLANCO. El objeto de ello era interesarse por su situación como Doctor honoris causa, habida cuenta de que no había acudido al acto de investidura, y, desconociendo si era preceptiva la asistencia, recabar la posibilidad de recibir el diploma acreditativo.

La gestión fue cumplidamente realizada, tal como resulta de los tres documentos siguientes:

1. ${ }^{\circ}$ En primer lugar, la carta oficial que el Secretario de la Universidad de Granada remitió a su homólogo de Salamanca:

Sr. Don Manuel García Blanco

Secretario General de la Universidad de Salamanca

Mi querido colega:

Le pongo estas líneas rogándole que me informe de una consulta que me hace el Prof. Hans Kelsens [sic], que según me dice fué [sic] propuesto Doctor Honoris Causa por esa Universidad, aceptando complacidísimo el nombramiento, aunque no le era posible desplazarse de los Estados Unidos, y como a pesar del tiempo transcurrido no se le ha enviado Diploma alguno, tiene la duda de si es realmente Doctor Honoris Causa por esa Universidad, o si es preceptiva su asistencia a la misma.

Según dice es Doctor Honoris Causa de otras Universidades, aún [sic] cuando no haya asistido al acto de la investidura solemne.

En espera de sus noticias y rogándole perdone estas molestias quedo suyo affmo. amigo y compañero.
3-7-1956.
Firmado: Antonio MESA-MOLES

2. ${ }^{\circ}$ En segundo lugar, el borrador de contestación que, en el mismo expediente ${ }^{14}$, figura adosada a la carta anterior sin firma ni fecha:

Contestación a la carta adjunta

Mi querido amigo y compañero: En contestación a su carta del día 3, que he encontrado aquí a mi regreso de Alemania, le agradeceré comunique al profesor Hans Kelsen, que recibirá el diploma con su nombramiento de Doctor «honoris causa» de esta Universidad, título que le fue concedido con ocasión del VII Centenario de la misma, en su residencia de los Estados Unidos, de manos de nuestra representación diplomática. A tal fin conviene que nos haga saber su dirección exacta para ese momento, que será en el próximo otoño. Si hubiésemos sabido que venía a España se habría activado la impresión del Diploma para que él mismo se lo llevase, pero ya no hay tiempo, pues no lo tendremos listo antes del próximo mes de septiembre.

Un cordial saludo de

3. $\quad \mathrm{Y}$ en tercer lugar, y sobre todo, la carta manuscrita que el propio KELSEN dirige al secretario salmantino (cuyo facsímil, en francés, aparece reproducido al final del presente trabajo):

Basilea, Suiza, 30 de julio de 1956

14 Los tres documentos que aquí transcribo obran en el Archivo Central de la Universidad de Salamanca (Exp. AC 17628/7). Tuve conocimiento de ellos a través de DELGADO PiNTO quien, según me contó en la carta antecitada, hizo copia de los mismos cuando fue secretario general de esa Universidad (1963-1967) con el permiso del entonces rector. Luego pude comprobar que habían sido ya publicados en el estudio de MARTíNEZ NEIRA, 2004: 206-207. 
Señor Manuel García Blanco

Secretario General de la Universidad de Salamanca

Salamanca, España

Amigo mío, el profesor Antonio MEsA-MolEs me ha informado de que tiene usted la enorme amabilidad de enviarme, en el próximo otoño, el diploma referente al Doctorado «Honoris Causa» que la Universidad de Salamanca me ha concedido. Permítame que le indique mi dirección exacta:

2126 Los Angeles Avenue,

Berkeley (cerca de San Francisco), California, USA

Aprovecho esta oportunidad para expresar una vez más mi sincero agradecimiento por el gran honor con el que una de las universidades más antiguas y célebres del mundo me ha distinguido.

Le ruego acepte, Señor Secretario General, el testimonio de mis sentimientos más sinceros.

Hans Kelsen

Como se ve, la carta de contestación a KELSEN desde Salamanca debió de ser enviada por el secretario GARCíA BLANCO dentro del mismo mes de julio, casi a vuelta de correo. La prueba de que así fue efectivamente (de que, por tanto, no quedó en borrador) es que la carta de KELSEN desde Suiza está fechada el 30 de julio y tiene por único objeto confirmar el dato de su dirección en Estados Unidos para el envío del diploma. La respuesta de KELSEN es muy pronta, como vemos (tal vez MESA-Moles le informó telefónicamente o por telegrama), lo que demuestra su gran interés por recibirlo. Ahora bien, lo que no sabemos es si el diploma en cuestión le fue finalmente remitido o no. No figura en los archivos del Hans Kelsen-Institut ${ }^{15}$. Tampoco consta documento alguno en el archivo de la Universidad de Salamanca que acredite el envío, como sí sucede en cambio con otros doctores honoris causa extranjeros nombrados en la misma ocasión y que fueron igualmente proclamados en ausencia. Se trata en particular del caso del hispanista Archer M. HunTINGTON, también procedente de Estados Unidos: en el archivo de la Universidad se conserva la misiva que José M. ${ }^{a}$ DE AREILZA, el entonces embajador de España en aquel país, dirigió en 1955 al Rector de Salamanca contestándole que con mucho gusto haría llegar a manos del señor HunTINGTON el diploma de doctor honoris causa ${ }^{16}$.

Más aún: no tenemos constancia siquiera de que KELSEN aceptara de manera formal el nombramiento en 1954. La carta de MESA-MOLES que acabamos de reproducir dice que lo aceptó «complacidísimo», y que su inasistencia fue debida a la imposibilidad de desplazarse desde Estados Unidos. Pero lo cierto es que eso tampoco está nada claro.

15 Preguntado al respecto Th. OleCHOWsKI, director junto con C. JABlONER del Hans Kelsen-Institut, responde a través de correo electrónico: «In fact, we do not possess the diploma itself, but we are sure that he received the certificate». Repreguntado por alguna prueba al respecto, matiza: «So there is no definitive proof that Kelsen has got the diploma ever».

${ }_{16}$ Universidad de Salamanca, Documentos de Doctores Honoris Causa designados para ser investidos el 10 de mayo de 1954 (AC 17628/7). No he podido confirmar que ninguna de ambas entregas tuviera efectivamente lugar, pues la embajada española en Washington, según comunicación por correo electrónico, «no tiene un archivo que llegue tan atrás». No hay prueba, por consiguiente, de que la promesa hecha a KELSEN por la Universidad de Salamanca se verificara. Y en el caso de HUNTINGTON resulta muy dudoso, ya que éste falleció apenas dos meses después de la citada carta de AREILZA. 
No existe evidencia documental directa de que KELSEN hubiera aceptado la investidura y excusara su asistencia en tiempo y forma mediante carta... ni tampoco de que rehusara el nombramiento: todo lo que sabemos fehacientemente es que no acudió al acto.

La única base documental que apoyaría que KELSEN aceptó el nombramiento como doctor honoris causa y rehusó asistir es de carácter indirecto. Se trata de la copia mecanografiada de un telegrama que el Rector de Salamanca envía a Madrid, al Ministerio de Educación Nacional. Dice así:

[Sello de la Universidad]

Núm. 179

RECTOR UNIVERSIDAD SALAMANCA A DIRECTOR GENERAL ENSEÑANZA UNIVERSITARIA-MADRID

Profesor Kelsen ha aceptado nombramiento «Doctor Honoris Causa» aunque no asistirá. Saludale [sic].

Firmado: Antonio Tovar

Salamanca, 4 mayo 1954

A desentrañar el sentido de estas exiguas palabras tendremos que dedicar luego algún detenimiento. Retengamos por el momento dos cosas: la fecha del telegrama (muy pocos días anterior a la fecha de la ceremonia misma) y su propio formato (que sugiere, según la hipótesis que vamos a conjeturar, un intercambio de telegramas o llamadas telefónicas con KELSEN en el que se le urgía a aclarar su posición en el último momento ante su falta de respuesta).

En cuanto al motivo con que, según MESA-MOLES, excusó su asistencia, la imposibilidad de viajar, no parece que fuera — provenga de MESA-MOLES o de KELSENen absoluto verosímil en esa época, por lo que luego diremos también. Parece, más bien, que la actitud de KELSEN fue la de guardar un cauto y prudente silencio, el cual se prolongó hasta un momento crítico que obligó a los organizadores del doctorado salmantino, temiendo que pudiese arruinarse la ceremonia, a contactar con él (y otros) para verificar su disposición a asistir o no a ella. Un silencio que, sin embargo, dos años más tarde —en 1956, ya en Granada- KELSEN reconsideró, hecho respecto del cual también es necesario dar alguna interpretación explicativa. Sí que resulta en cambio un motivo más fundado el de que a KELSEN ya le habían sido concedidos por otras universidades doctorados honoris causa en ausencia, esto es, sin asistir al acto de investidura. Ello sucedió, en realidad, en una sola ocasión: el doctorado concedido por la Universidad Nacional Autónoma de México (con motivo curiosamente también de un centenario, esta vez el cuarto) en agosto de 1951 ( $c f r$. FLORES, 2014: 58), y que KELSEN no pudo recibir entonces personalmente. Ahora bien, el doctorado de la Universidad de Salamanca era completamente singular por sus características y por sus circunstancias políticas. Es hora ya de que nos adentremos en ellas.

\section{UN DESHONROSO DOCTORADO HONORIS CAUSA}

En la página 32 de la Memoria de la Universidad —entonces «Literaria»- de Salamanca que recoge las actividades académicas del curso 1953-54 puede verse el siguiente cuadro: 


\section{TÍTULOS DE DOCTOR «HONORIS CAUSA» CONCEDIDOS POR LA UNIVERSIDAD DE SALAMANCA Y FECHA DE SU CONCESIÓN}

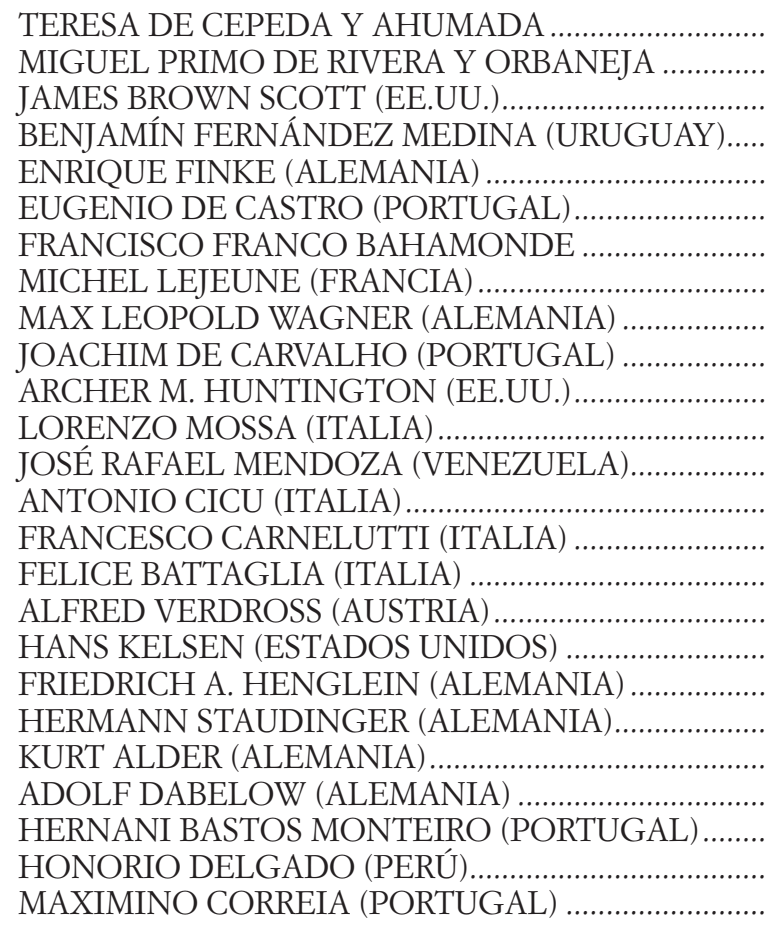

(1922)

(1926)

(1927)

(1927)

(1929)

(1934)

8-V-1954

$10-\mathrm{V}-1954$

10-V-1954

10-V-1954

10-V-1954

10-V-1954

10-V-1954

10-V-1954

10-V-1954

10-V-1954

10-V-1954

10-V-1954

10-V-1954

10-V-1954

10-V-1954

10-V-1954

10-V-1954

10-V-1954

10-V-1954

Como se comprueba, la nómina de doctorados honoríficos no era muy abultada antes de 1954, aunque comenzase nada menos que con una Santa y continuase con un Dictador. Pero ese año marca claramente un hito: entonces se conmemoró, como hemos adelantado, el VII Centenario de la Universidad y para celebrarlo se decidió conceder 19 doctorados honoris causa de una sentada. Todo un prodigio, no hay duda, para los anales del protocolo académico.

Más adelante en la misma Memoria se hace una «Crónica abreviada» del Centenario. Tras el relato de todos los antecedentes y celebraciones que tuvieron lugar ya desde octubre de 1953, se pasa a la narración de los actos de clausura, que dan comienzo el 8 de mayo de 1954:

Y en esa solemne ocasión el Jefe actual del Estado español, S. E. el Generalísimo Francisco FRANCO recibió la investidura de doctor "honoris causa" de nuestra Facultad de Derecho.

El 10 de mayo fueron investidos, en efecto, los doctores extranjeros, todos ellos académicos: LeJEUne (La Sorbona), Wagner (Berlín) y CARvalho (Coimbra), por Letras; Mossa (Pisa) y Mendoza (Caracas), por Derecho; Henglein (Karlsrühe) en Ciencias; y DABElow (Mainz), BASTOS (Oporto), Delgado (Lima) y CoRREia (Coimbra), por Medicina. En total, diez doctores honoris causa por las cuatro Facultades entonces existentes. 
Pero ¿qué fue de los ocho restantes? En la Memoria aparecen mencionados enseguida los doctores ausentes:

También fueron proclamados doctores «honoris causa», en ausencia, y les serán remitidos sus nombramientos, los siguientes: Por la Facultad de Filosofía y Letras: Mr. Archer M. Huntington, de Estados Unidos, fundador de la Hispanic Society of America, de Nueva York. Por la de Derecho: los profesores Antonio CICU y Felice BATTAGLiA, de la Universidad de Bolonia; Francesco CARNELUTTI, de la de Roma; Alfred Verdross, de la de Viena, y Hans Kelsen, de la de California. Y por la de Ciencias: los profesores Hermann STAUDINGER, de la Universidad de Friburgo de Brisgovia (Alemania) y Kurt Alder, de la de Colonia ${ }^{17}$.

Hasta aquí el resumen puramente académico de la ceremonia, tal como es relatado en la Memoria. Pero éste era en realidad un acto que desbordaba ostensiblemente la esfera de la academia. Para comprender plenamente su significado hay que contemplar los fastos del Centenario como lo que realmente fueron: una formidable operación de legitimación política del régimen franquista nacional-católico en su primer periodo, cuando aquella nueva España salida de la guerra civil, y ahora también supérstite de la guerra mundial, necesitaba ser apuntalada ideológicamente por todos los medios. A ello se prestaba a la perfección el centenario salmantino: permitía hacer confluir lo académico (la Universidad), lo eclesiástico (el Catolicismo) y lo político (el Imperio) del modo más propicio y con toda la parafernalia y prosopopeya precisas para los intereses ideológicos del régimen (cfr. PÉREZ DELGADO, 2006; VVAA, 2011).

A fin de llevar a cabo aquella histórica conjunción hasta las fechas se manipularon. En rigor el centenario de la Universidad ni siquiera tocaba en 1954: los Studii Salmantini fueron fundados por Alfonso IX en el año 1218 (de hecho, el VIII Centenario está programado para 2018). Se aprovechó oportunistamente que Alfonso X el Sabio le otorgara en 1254 el título de Universidad en Real Cédula de 8 de mayo (la famosa Carta Magna que regiría sus 12 cátedras). Semejante correlación histórica no podía dejarse pasar y así (dado que en 1943 la guerra lo imposibilitó y 1955 era, al parecer, esperar mucho) se celebraría el Centenario en el curso 1953-54: y el día elegido para la investidura del Jefe del Estado, el Generalísimo Francisco FrANCO, sería precisamente el 8 de mayo de $1954^{18}$.

Pero el evento se planificó, obviamente, desde mucho antes. El acuerdo del claustro de la Universidad que propone la investidura de FRANCO es de seis años antes: del 9 de junio de $1948^{19}$. Con todo la cosa venía naturalmente de más atrás: las co-

17 Universidad de Salamanca, Memoria correspondiente al Curso Académico de 1952-1953. Actividades académicas del de 1953-54, Salamanca, Talleres Gráficos Núñez, 1954, 76 y ss., 85, 88.

${ }_{18}$ Cfr. Universidad de Salamanca, Memoria correspondiente al curso académico de 1951-1952. Actividades académicas del de 1952-53, Salamanca, Talleres Gráficos Núñez, 1953, 66 y ss.; VII Centenario de su constitución definitiva por Alfonso X El Sabio, 1254-1954. Programa de los actos conmemorativos que tendrán lugar los dias ocho al doce de octubre 1953, AC 7566/2.

19 Universidad de Salamanca, Libro de Actas del Claustro Ordinario, AUSA 548, 101 y ss.; Memoria correspondiente al Curso Académico de 1946-1947. Actividades académicas del de 1947-1948, Salamanca, Imprenta y Librería Hijos de Francisco Núñez, 1948, 46. El rector era Esteban MADRUGA, catedrático de Derecho civil, nombrado por FRANCO en 1936 después de cesar a UNAMUNO. Convoca este claustro para elevar un escrito firmado por 24 catedráticos ocho días antes en el que «consideran que el primer Doctor "honoris causa" por la Universidad de Salamanca [...] debe ser el Jefe del Estado, Generalísimo de los ejércitos de Tierra, Mar y Aire y Caudillo de España, quien con su actuación en la Guerra de Liberación primero, y en las tareas del Gobierno 
nexiones de FRANCO con la Universidad salmantina se remontaban a la guerra civil, y hasta 1953-1954 hubo largo tiempo para planear minuciosamente una operación político-académica como aquella. Ello no tuvo lugar sólo en Salamanca, sino también en el Ministerio de Educación Nacional, el de Información y Turismo y hasta el de Exteriores, como veremos: es decir, desde el Gobierno. La ceremonia salmantina del Centenario y el doctorado honoris causa con que se clausuró constituye una especie de fractal que reproduce la estructura del régimen de FRANCO — sus diversas y contradictorias caras - en esa década de los años cincuenta, una de las más oscuras de nuestra historia.

Ya desde la guerra la Cátedra salmantina se había convertido, en palabras de algún cronista local, en la «Cátedra Nacional», paralelamente a como la ciudad de Salamanca se convirtió en la capital político-militar del bando sublevado. Aquí fue elegido FrAnCO Jefe del Gobierno del Estado Español («quien asumirá todos los poderes del nuevo Estado») por la Junta de Defensa Nacional en Decreto de 29 de septiembre de 1936. Y aquí, en el Palacio Episcopal, instaló su cuartel general hasta el final de la guerra (la capital administrativa fue Burgos), tras la cual emprendió la edificación en efecto del «Nuevo Estado» a base de demoler sistemáticamente las estructuras políticas de la República. Sólo tres días antes de la proclamación de FRANCO, el claustro de la Universidad (aún presidido por UNAMUNO) había dirigido un «Mensaje a las Universidades y Academias del mundo acerca de la guerra civil española», alineándose con claridad a favor del levantamiento ${ }^{20}$. Durante los tres años de la contienda la actividad académica se redujo prácticamente a cero ${ }^{21}$. Pero el dictador sí que había visitado el paraninfo salmantino durante esos años. Lo sabemos por la relación que el Rector MADRUGA hace de las actividades universitarias durante la guerra en la Memoria del curso 1939-1940, la primera que se publica acabada la contienda. Ahí, además de publicarse el citado Mensaje a las universidades del mundo en recio latín ${ }^{22}$, se da cuenta de la clausura por FRANCO de unos cursos de magisterio en el Paraninfo «marcando a todos los profesores de España la ruta a seguir con las siguientes palabras: "No perdió su hora el Caudillo al venir aquí, dejando por un momento las tareas relacionadas con los frentes; que si allí se libran batallas de las armas, aquí se libran batallas de fe y de

de la paz después prestó un inestimable servicio a la Patria y a la Civilización occidental» (101-102). El escrito, al que el rector se adhiere «fervientemente», tenía por primer firmante a José BELTRÁN DE HEREDIA, catedrático de Derecho civil y otros 23 catedráticos, entre ellos Antonio Tovar, el que sería rector en el Centenario. Es aprobado sin embargo «por aclamación», no por unanimidad, dado que el número de catedráticos era de 36 y sólo había 28 asistentes. Tres catedráticos ausentes secundan la propuesta por telegrama. Los cinco restantes (que no firmaron el escrito de propuesta ni asistieron ni se adhirieron a distancia) eran: Fernando GALÁN GUTIÉRreZ (Ciencias), José Antón OnECA, Julio Tejero Nieves y Francisco ElíAs DE Tejada (Derecho), y Miguel Moraza OrTega (Medicina). Cfr. Infante, 2015: 16-7, n. 41.

20 Cfr. Libro de Actas del Claustro Ordinario, op. cit., 80 y ss. UnAMUNO, como se sabe, había hecho un donativo económico personal al Alzamiento. Después tuvo lugar su famoso enfrentamiento con MiLLÁN ASTRAY en el Paraninfo y su destitución como rector.

21 Dejó de publicarse la Memoria anual de la Universidad y, a juzgar por las actas, sólo hubo en ese tiempo cuatro reuniones del Claustro. Tampoco después de la guerra tuvo éste actividad hasta 1947, con una sola reunión. A ésta le sigue la de 1948 que propuso a FRANCO como honoris causa, y para la siguiente hay que esperar hasta 1952, ya con Antonio TOVAR como rector.

22 Universidad de Salamanca, Memoria sobre el estado de la instrucción en esta Universidad y establecimientos de enseñanza de su distrito, correspondiente al curso académico de 1938 a 1939. Anuario para el de 1939 a 1940. Variedades, Salamanca, Imprenta y Librería Hijos de Francisco Núñez, 1940. Al mensaje sigue la carta de adhesión del rector de la Universidad de Bonn, cerrada con un estentóreo «¡Heil Hitler!» (46-47). 
verdad" ${ }^{23}$. También encontramos en esa Memoria a un personaje que ya conocemos: J. YANGUAS MESSíA, el que sería presidente del Institut de Droit International en Granada, quien en 1937 fue invitado por la Facultad de Derecho (cuyo Decano era Manuel TORRES LÓPEZ) a pronunciar un ciclo de conferencias sobre «Beligerancia y Nuevo Estado» publicadas por la Universidad el año siguiente ${ }^{24}$.

Como puede verse, en los años de posguerra la universidad española, y a su frente Salamanca como buque insignia, fue un instrumento más - aunque uno muy valiosoal servicio de la construcción del armazón ideológico del franquismo, una amalgama de falangismo, integrismo y tradicionalismo que se fraguó en esos primeros años ${ }^{25}$. El régimen franquista añadía al componente personalista y totalitario típico de los fascismos nacidos de la crisis de las democracias liberales en los años treinta un fuerte elemento nacional-católico y tradicional cuya principal determinación (y lo que le daba unidad interna) era, después de ganar la guerra, eliminar todo rastro de las ideas e instituciones próximas al liberalismo o la democracia, vistas como culpables de los males de la nación durante el último siglo. La peculiar y conflictiva combinación de las fuerzas del régimen (militares, falangistas, católicos y monárquicos, cuyas manifiestas pugnas fueron siempre instrumentalizadas por FRANCO) y la concentración cesarista del poder en manos de éste, con su habilidad para conservarlo mediante un rígido control social autoritario, marcaron su singularidad durante décadas (JuliÁ, 1999; MORADIELLOS, 2000; SAZ CAMPOS, 2013).

Tan pronto terminó la guerra, el lenguaje bélico, de trinchera, primero, y el de represión y depuración ideológica después ${ }^{26}$, dieron paso a un discurso monolítico de justificación y «normalización», no menos violento y represor, que se mantuvo vigente prácticamente hasta entrada la década de los 60. La más lúcida definición de ese escenario es lo que ORTEGA Y GASSET (1965: 87, 356n.) acuñó como el «tibetanismo» político y cultural de España. La política de autarquía sucesiva a la economía de guerra se acompañó de tempranas tentativas de institucionalización del régimen mediante una serie de «leyes fundamentales» ${ }^{27}$. Los actos del Centenario de la Universidad de Salamanca y el

23 Ibid., 43. El 18 de julio de 1937 se conmemoró en el paraninfo «el primer aniversario de iniciación de la gesta española [...] poniéndose de manifiesto la comunión espiritual de las Armas y de las Letras en nuestra Gloriosa Cruzada» (pág. 44).

24 Puede verse el sumario de las conferencias ibid., 48-49.

25 Cfr. Fuentes Labrador, et al., 1991. Por supuesto, también la Universidad (y particularmente Salamanca) se benefició de su simbiosis con el régimen. Salamanca fue la primera universidad española a la que se concedió la potestad de conferir el grado de doctor, hasta entonces centralizada en Madrid ( $c f r$. el Decreto de 6 de noviembre de 1953, donde se reconoce la conexión de este hecho con el Centenario). La aparente contradicción del principio jurídico qui potest plus, potest minus (la misma universidad que convertía a FRANCO en doctor honoris causa no podía nombrar doctores ordinarios) resultaba muy fácil de explicar: no era en realidad Salamanca quien otorgaba ese doctorado sino Dios y la Historia, como vamos a ver.

${ }^{26}$ La Ley de Responsabilidades Políticas de 1939 y la de Represión de la Masonería y el Comunismo de 1940 produjeron condenas a muerte, encarcelamientos y depuraciones para decenas de miles de personas haciendo pequeño el saldo de víctimas de la propia guerra. Sobre la depuración académica en las facultades de derecho, cfr. RODRÍGUEZ LóPEZ, 2008.

27 Éstas fueron el Fuero del Trabajo (1938), la Ley de Cortes (1942), el Fuero de los Españoles y la Ley del referéndum nacional (1945), la Ley de sucesión a la Jefatura del Estado (1947). Sólo después del abandono de la autarquía y con el cambio de política económica producido a partir de los años sesenta puede considerarse consolidado tal proceso de institucionalización (Ley de Principios del Movimiento, 1958 y Ley Orgánica del Estado, 1967). 
doctorado bonoris causa concedido a FRANCO deben insertarse en este marco como un paso ideológico más en tal dirección. Una vez que el Eje fue derrotado en 1945, surgió la necesidad de legitimarse no sólo interna sino también externamente para un régimen que además de aislado estaba también condenado en el plano internacional. Y así es como, entre 1948 y 1954, pudo surgir la idea de organizar una «ceremonia honoris causa masiva»: convocar en Salamanca a un gran número de académicos extranjeros de prestigio permitiría neutralizar la idea de que el de FRANCO era un régimen asociado al exilio y la autarquía intelectual ${ }^{28}$. Este doble propósito, interno y externo, quedaba reflejado en las fechas dejando perfectamente clara la prioridad: FRANCO, el día 8 de mayo de 1954 (la efemérides histórica); los doctores extranjeros, el día $10^{29}$.

El Centenario logró congregar a representantes de 123 universidades y 44 países a lo largo de todas las celebraciones cuyo colofón fue el doctorado honoris causa de FRANCO. Sin duda, el prestigio histórico de la universidad salmanticense era poderoso fuera de nuestras fronteras. Sin embargo, el evento no consiguió dejar de ser efectivamente «tibetano» pese a todo. No de otra manera cabe calificar, para empezar, que mientras en el concierto internacional los países occidentales prácticamente acababan de juzgar los crímenes nazis y de redactar la Declaración de los Derechos Humanos, aquí estuviera proponiéndose la más alta distinción universitaria al jefe de un régimen totalitario fascista, el único superviviente en Europa (junto al portugués), nacido de un golpe militar contra una república democrática. En su Memoria dirigida al Ministerio, el rector TOVAR justificaba que el grado de doctor concedido a FRANCO fuera precisamente en Derecho ${ }^{30}$ aseverando que «le han hecho acreedor sus méritos como protector de la cultura, legislador y juez justo» ${ }^{31}$. «Tibetano» fue también el desarrollo

${ }^{28}$ Los actos de conmemoración del Centenario comenzaron en 1953 con unas Jornadas de Lengua y Literatura Hspanoamericanas y una Asamblea de Universidades Hispánicas que concluyeron el 12 de octubre, fiesta de la Raza. Ambos eventos pretendían materializar la apariencia del fin del aislamiento internacional de España echando mano de los lazos americanos y los vestigios ideológicos del pasado imperial. La labor fue desde luego muy ardua. En ella intervino activamente el Instituto de Cultura Hispánica de Madrid, de la mano del Secretario de la Oficina de Educación Iberoamericana, Carlos LACALLE, quien iba informando de las Universidades que iban a asistir o enviaban mensajes de adhesión. En carta de 21 de mayo al secretario GARCíA BLANCO, LACALLE dice: «no estoy demasiado satisfecho de la marcha de nuestras invitaciones», pues «solamente cuatro ha enviado la tarjetita [de adhesión]». Las invitaciones habían sido cursadas hacia abril (Asamblea de Universidades Hispánicas, AC 7566/1). En carta del 22 abril al rector TOVAR confiesa a LACALLE: «creo que empujando - pero empujando celtibéricamente— la asamblea va a constituir un buen triunfo» y deja claro que «de la propaganda en América nos encargamos nosotros» (ibid.). Y así fue efectivamente: las universidades que designaron representante ascendieron a 71 y se adhirieron otras 23 . Para el acto de clausura parece que iba a contarse con la presencia del mismo FrANCO, algo que finalmente se descartó y ello fue visto como un «problema» (Carta de 11 de agosto de 1953 de Carlos LaCALLE al rector Tovar, ibid.). Sobre ambos eventos puede verse la Crónica Gráfica de los actos del VII Centenario de la Universidad de Salamanca, 8-12 octubre 1953, Salamanca, Talleres Tipográficos Yglesias, s. d. [1954] (VII Centenario. Publicaciones, AC 7566/5), y el documental que NO-DO («Noticiarios y Documentales») dedicó a la celebración del Centenario («Salamanca y su Universidad, VII Centenario de la Universidad de Salamanca»): bttp://www.rtve.es/filmoteca/no-do/not563/1483334/ [fecha consulta 15 de febrero de 2015].

29 En el programa oficial de actos queda significativamente relegada a mera nota a pie de página la investidura «de los profesores extranjeros recientemente nombrados» (Programas de actos. Invitaciones. Protocolo. Alojamiento, AC 7566/2). El día 9 era domingo.

${ }^{30}$ En 1965 la Universidad de Santiago de Compostela nombró a FRANCO Doctor honoris causa en Ciencias.

31 Memoria dirigida al Director General de Enseñanza Universitaria, 17 de marzo de 1953 (VII Centenario de la Universidad. Organización y presupuestos 1952-1953, AC 7565/1). 
mismo del acto. A diferencia del evento de Granada, donde se guardaron las formas (el significado diplomático internacional de la reunión así lo imponía), en Salamanca no hubo autocontención alguna. La investidura de FRANCO fue una obscena exhibición de las esencias totalitarias del régimen. Vino acompañada de los inevitables baños de masas (convenientemente aleccionadas y pagadas) que solía darse el caudillo, esta vez en la ciudad y la provincia salmantinas, donde los testimonios gráficos permiten constatar la perfecta vigencia popular del saludo romano ${ }^{32}$. La ceremonia en sí misma no sólo estuvo repleta de militares y clérigos sino que en ella hasta el Cara al Sol compitió con el Gaudeamus. FrANCO compareció con uniforme de capitán general. Tras asistir a un Te Deum en la Catedral, donde entró y salió bajo palio, y después de pasar revista a las milicias universitarias en el atrio, se dirigió al Paraninfo precedido de todo el claustro siendo recibido con todos los honores para presidir la sesión. Se modificó el protocolo académico a fin de que Carmen Polo de FRANCO ocupara un sitial preferente y elevado al lado derecho del estrado académico, desplazando a los galardonados. Entre las autoridades políticas tuvo también un sitio especial Pilar Primo de Rivera, jefa de la Sección Femenina de la Falange Española ${ }^{33}$. El doctor oficiante de padrino, Francisco HeRnández Tejero (catedrático de Derecho Romano y Decano), hizo una laudatio que fue en realidad adulatio ${ }^{34}$. A continuación dio inicio el antiguo ceremonial latino de imposición del grado de doctor, que había sido especialmente restaurado para la ocasión. El rector TOVAR en su discurso acuñó este académico lema: «El Caudillo para la Universidad, la Universidad para el Caudillo». En respuesta, el Generalísimo, empequeñecido aún más bajo un colosal busto de sí mismo dominando toda la estancia, atizó un discurso de agradecimiento en el que (emocionado, al parecer) lo que comenzaba agradeciendo al claustro salmantino era que «habéis sin duda querido premiar su espíritu de servicio al progreso de la cultura» a «este nuevo y modesto doctor». A continuación esa modestia no le impidió formular una comparación entre «los que por la responsabilidad en que la vida nos colocó venimos haciendo historia al enfrentarnos con la tarea trascendente de levantar a España del caos» y «aquellos caudillos reales que en nuestro siglo XIII, en los descansos de su victoriosa Reconquista, sentaban los pilares sobre los que habría de levantarse la gloriosa Universidad salmantina». El resto del discurso apelaba sin ambages al más rancio iusnaturalismo teocrático ${ }^{35}$. Esa misma

32 Como relata INFANTE, para FRANCO la ocasión constituyó una especie de retorno victorioso a su antiguo cuartel general, 17 años después y «al menos en este terreno, la supresión (o el ocultamiento) de símbolos y elementos fascistas no estaba muy avanzada». Se hizo acompañar, en efecto, de casi todo el gobierno, de todas las autoridades políticas, religiosas y militares de la región, de una amplia mesnada de periodistas de Madrid... y de la «Legión José Antonio» (unos 6.000 hombres), revistada el día anterior por la propia Guardia de Franco (lo que demuestra que todavía a mediados de los cincuenta el régimen ponía en marcha un imponente aparato paramilitar). Pueden verse abundantes datos y referencias de la prensa de la época en INFANTE, 2015: 11 y ss., 24 .

33 El 5 de octubre de 1953 el rector TOVAR cursa carta de invitación a su «querida amiga y camarada» (VII Centenario. Correspondencia, AC 7566/3).

34 No puedo resistirme a citarlo: «Quien se había mostrado esforzado conductor de legiones, había de asumir la tarea magnífica de regir un Estado. Surge entonces el estadista genial, el legislador que sabrá dar vida en la norma adecuada a los legítimos anhelos de su pueblo; el juez que conoce la clave de la jurisprudencia clásica» (INFANTE, 2015:18).

35 «Jamás admitiremos que se invoque el derecho para acabar contra toda posibilidad de vida legal, de vida bajo el imperio del único derecho verdadero: el de servir a la justicia bajo la ley eterna de Dios [...] Dios, que es fuente y razón de toda ley, de todo poder y de todo derecho» (ibid., 19). El discurso íntegro puede leerse en $A B C, 9$ de mayo de 1954. 
tarde, coherentemente, la Universidad Pontificia le otorgaba su propio doctorado bonoris causa en Teología. FRANCO terminó, por lo visto, llorando a lágrima viva.

El acto estuvo, pues, evidentemente exento de todo honor académico ${ }^{36}$. Cincuenta y cuatro años después, en 2008, el Consejo de Gobierno de la Universidad de Salamanca acordaba rechazar la concesión del grado de doctor bonoris causa a FRANCO «por entender que nunca reunió méritos científicos, académicos, sociales, ni personales que lo hicieran merecedor de ostentar dicho honor» ${ }^{37}$.

$\mathrm{Y}$, en fin, no menos estrambótico y «tibetano» fue también que casi la mitad de los doctores extranjeros que debían ser investidos en la ceremonia del día siguiente no estuvieran presentes en el acto (al que, por supuesto, FRANCO no se quedó). Eran ocho los ausentes - frente a diez asistentes-y KELSEN, como sabemos, estaba entre ellos.

\section{JURISTAS Y IUSFILÓSOFOS EN TORNO AL IV CENTENARIO SALMANTINO}

Si nos fijamos en la composición del panel de galardonados llama la atención que los juristas fueran amplia mayoría entre ellos. Eran tres doctores en Medicina, cuatro en Ciencias, cuatro en Letras, y siete en Derecho. Y entre los juristas dominaban los iusfilósofos: casi todos ellos podían considerarse tales. Un personaje clave para entender este hecho, así como el diseño del evento en su conjunto, es quien entonces ocupaba el cargo de ministro de Educación Nacional, Joaquín RuIZ-GimÉNEZ. Éste había sido nombrado en el cambio de gobierno de 1951, decimoquinto aniversario del alzamiento, con el que FRANCO quiso hacer un lavado de cara del falangismo y recomponer la correlación entre facciones del régimen, en vista sobre todo del nuevo orden internacional emergente tras la guerra mundial.

RUIZ-GIMÉNEZ era precisamente catedrático de Filosofía del Derecho en Salaman$\mathrm{ca}^{38}$. Su perfil era el de un universitario católico (MuÑOZ SORO, 2006), de estirpe familiar política, que antes de la guerra había comenzado su carrera en derecho internacional como ayudante precisamente de YANGUAS MESSíA, a quien años después sustituiría al frente de la embajada en Roma. Allí dirigió las negociaciones del Concordato con la Santa Sede (1948-1951) que se firmaría posteriormente $(1953)^{39}$. Llegó al gobierno de

36 Puede verse el resumen documental del NO-DO: http://www.rtve.es/filmoteca/no-do/not-593/ 1486420/ [fecha consulta 15 de febrero de 2015]. Toda la grandilocuente escena es óptima materia prima para una película de BERLANGA o una novela de CERCAS. Encuentra su perfecto desenlace en la conocida anécdota del vítor (la inscripción gráfica para celebrar el doctorado que solía pintarse en los muros de la Universidad) que se dedicó a FRANCO. Al parecer, fue el último que se realizó con el material artesanal anterior al uso de tintes sintéticos: una mezcla de sangre de toro caliente, almagre y pimentón. La inscripción representa el yugo y las flechas junto con una pluma y la leyenda Generalissimo Franco Mil. Hisp. Glor. Estas abreviaturas debían significar «glorioso soldado español». Pero, según los estudiosos, el malévolo y culto autor incluyó una pequeña venganza: Miles Gloriosus era también el título de la obra de PLAUTO El soldado fanfarrón cuyo protagonista era ridiculizado.

37 InFANTE, 2015: 20. La Universidad de Santiago había hecho lo propio en 2006.

38 Había permutado con ELÍAS DE TEJADA su cátedra de Sevilla en 1951, dos meses antes de entrar en el gobierno.

39 Ruiz-Giménez hizo su tesis doctoral con M. Puigdollers (La concepción institucional del Derecho, Madrid, Instituto de Estudios Políticos, 1944, donde defendía un «totalitarismo cristiano»). En 1943 consigue la cátedra de Filosofía del Derecho y Derecho Natural de la Universidad de Sevilla. En 1945 publica el manual 
la mano de A. MARTín-ARTAJO con el prestigio diplomático ganado intentando recomponer internacionalmente la posición de España, una tarea ciertamente complicada en aquella coyuntura ${ }^{40}$. RuIZ-GIMÉNEZ concibió la Universidad como un instrumento político para tender puentes con los exiliados y los depurados ${ }^{41}$, y también — seguramente con no poca ingenuidad - como vehículo para una futura reconciliación. En tal sentido, como ministro inició reformas en la enseñanza universitaria que supusieron cierta renovación (planes de estudio, selección del profesorado, doctorado) ${ }^{42}$. Nombró a varios rectores entre la generación de jóvenes intelectuales falangistas vinculados a Dionisio RIDRUEJO y la revista Escorial: P. LAÍN (Madrid), A. TOVAR (Salamanca), T. FERNÁNDEZ Miranda (Oviedo), L. SÁNCHEZ Agesta (Granada). Los dos primeros jugaron un papel determinante en esos años (el tercero, como se sabe, lo tuvo años después durante la transición). A todos ellos los encontraremos en los actos del Centenario salmantino.

De Ruiz-GiménEZ se ha escrito, sobre todo por parte de algunos de esos otros correligionarios suyos (quienes también lo dijeron de sí mismos), que representaba un talante «aperturista» o «liberal». Comillas aparte ${ }^{43}$, lo cierto es que esta calificación obtiene su sentido, si tiene alguno, esencialmente por contraste con el integrismo e inmovilismo circundantes. Un buen conocedor suyo, Elías DíAZ, quien inició su carrera académica con él en Salamanca, ha escrito que sólo después de su reincorporación a la cátedra, tras cesar como ministro, comenzaría RUIZ-GIMÉNEZ una evolución personal e intelectual hacia posiciones liberales y democráticas ${ }^{44}$. Por lo demás, como señala

Introducción elemental a la filosofía jurídica cristiana (Madrid, Ediciones y Publicaciones Españolas S.A.). Tras cesar como ministro en 1956 vuelve a Salamanca hasta 1960, año en que se traslada por oposición a la Universidad Central de Madrid, después Complutense.

${ }^{40}$ No solamente el Vaticano había sido reacio a firmar un Concordato con FRANCO como Jefe de Estado (como lo muestra la duración de la negociación, finalmente exitosa para el régimen), sino que también habían sido eficaces las gestiones de RUIZ-GIMÉNEZ como presidente de la organización católica internacional Pax Romana, cuando viajó recién acabada la guerra mundial a diferentes universidades de Estados Unidos, donde trató de atenuar los recelos contra España para terminar consiguiendo que en 1946 esa institución celebrara su XIX Congreso en España (precisamente en Salamanca, en la Universidad Pontificia, y en El Escorial). Pueden verse las actas completas de este congreso en la web filosofia.org.

${ }^{41}$ Miaja de la Muela, Recaséns Siches y el mismo Ortega y Gasset (a cuyo entierro acude en 1955) son algunos ejemplos. Pero la mayoría de estas operaciones no pasaron de ser intentonas, dada la hostilidad ambiente. Por ejemplo: a UnAmuno se le había dedicado la lección de apertura del curso 1952, a cargo de GARCía BLANCO. Éste era el editor de las obras de UNAMUNO a quien sucedió en su cátedra y también, recordemos, secretario de la Universidad (1939-1956) y actor en nuestro relato como corresponsal de KELSEN. Dos años después, en 1954, coincidiendo con los actos del Centenario de Salamanca se inauguró la Casa-Museo de UnAmuno, lo que dio ocasión a un tal obispo PiLdain para relinchar la pastoral «Don Miguel de Unamuno, hereje máximo y maestro de herejías».

42 En 1951 cambia el sistema de provisión de cátedras (las llamadas «oposiciones patrióticas»), lo que permitió el acceso de profesores como LÓPEZ-ARANGUREN y VALVERDE. En 1953 aparecen los nuevos planes de estudios que, por lo que respecta a las facultades de derecho, como sabemos, posteriormente no hicieron más que deteriorarse progresivamente hasta el estado lamentable de nuestros días.

${ }^{43}$ Como ha sido señalado muchas veces, este aperturismo nunca pudo ser realmente liberal: el horizonte natural de evolución política previsto por los católicos era más la monarquía tradicional (corporativa, orgánica y vertical) que la recuperación de las instituciones políticas liberal-democráticas (sufragio universal, pluralismo político de partidos, derechos individuales). Para el nacionalcatolicismo español, el «liberalismo es pecado» (por recordar el muy famoso título de SARDÁ). Sólo cuando las condiciones socio-económicas lo hicieron no ya posible sino necesario, ultimando ya la década de los setenta —y una vez que el dictador muriese en la camapudo producirse en España una transición política a la democracia.

44 DíAz, 2009a, 18, 29 y ss. Elías Díaz se licenció en derecho en Salamanca en el curso 1955-1956, el mismo en que se reincorporó RUIZ-GIMÉNEZ a la docencia, y comenzó a colaborar como ayudante en su cátedra primero allí y después, en 1960, en Madrid, ibid., 16. 
JuLIÁ fue más bien, paradójicamente, su descabalgamiento del poder lo que convirtió a los falangistas en liberales, intelectuales «comprensivos» frente a los «excluyentes»o intransigentes que inmediatamente les sustituyeron en la hegemonía cultural y universitaria (vinculados al Opus Dei y los Propagandistas) ${ }^{45}$. Las iniciativas reformadoras y reconciliadoras de RUIZ-JIMÉNEZ, de cualquier modo, no prosperaron: como hemos dicho, constituían tentativas perfectamente inidóneas en aquel medio. Terminó enfrentado con los sectores más reaccionarios y fue destituido a raíz de las primeras protestas estudiantiles pro democracia de febrero de 1956. Estas revueltas, protagonizadas por una generación que ya no vivió la guerra, y duramente reprimidas (cfr. MESA, 1982), constituyeron, también paradójicamente, el germen de la primera oposición política que ya nunca abandonaría la Universidad cumpliendo, esta vez sí, un papel transformador del régimen en las décadas siguientes. De modo que, como sucedió siempre con éste, la «liberalización» fue más una consecuencia que un resultado intencional. Años después, tras su giro ideológico, RuIZ-GimÉNEZ definiría su paso por el gobierno de FRANCO «no como un infierno, porque tuvo término» ${ }^{46}$.

Cabe pensar plausiblemente, volviendo al doctorado de Salamanca, que RUIZ-GIMÉNEZ hubo de tener un protagonismo directo en la organización académica del mismo si es que no fue enteramente diseño suyo. Es probable que fuera él quien decidió que los juristas fueran mayoría entre los destinados a ser nombrados honoris causa para mayor gloria de FRANCO e incluso que los eligiera personalmente. Pues la mayoría de ellos eran italianos, ambiente intelectual muy bien conocido por él, y respondían al patrón de filosofía social-cristiana conservadora que él mismo profesaba. Tal era, en efecto, el caso de Battaglia, Cicu, Mossa y CARnelutTi ${ }^{47}$. La elección de Verdross, por su parte, resultaba políticamente muy cómoda: habiendo sido uno de los principales integrantes de la Wiener Schule, era sin embargo católico, se había apartado del iuspositivismo kelseniano y en su obra como internacionalista recuperaba precisamente la herencia de la escuela clásica iusnaturalista española (Vitoria y Suarez) ${ }^{48}$. El caso de KELSEN era, en cambio, totalmente distinto. Sin duda también estaba RUIZ-GIMÉNEZ, por oficio, en buena situación para conocerlo bien, o al menos para calibrar la talla de su figura intelectual así como su prestigio en España antes de la guerra, y también para saber de su condición de refugiado primero y nacional después de Estados Unidos. Con todo, la decisión de incluirlo era ciertamente de muy difícil encaje en un contexto como aquel.

45 Cfr. Juliá, 2002. Esa clasificación entre «comprensivos» y «excluyentes» procede, como se sabe, de Dionisio RIDRUEJO e iba dirigida contra el grupo de Rafael CALVO SERER.

46 RODRÍGUEZ DE LECEA, 2013: 35. En sus diarios anota, ya en 1967, su agradecimiento a Dios por haberle alejado de aquel «ambiente anacrónico, pero que hace quince años me parecía normal» (ibid.). Sobre la evolución intelectual de RuIZ-GIMÉNEZ, cfr. DÍAZ, 2009b: 84ss., y 2009a. Elías DíAZ compendia esa evolución en la siguiente frase: «fue siempre a mejor, a mucho mejor», y destaca su papel como «eficaz aglutinante de las gentes e ideas que configuraron la revista y casa editora que fue de 1963 a 1976 Cuadernos para el diálogo», en donde se concentró «buena parte de la cultura plural y del pensamiento político que enlazaría con la preexistente oposición a la dictadura y sin la cual no se entiende del todo la cultura política de la transición, ni la posterior construcción de la democracia en nuestro país» (ibid, 15, 17). Vid. también HierRo, 1997, 2010; GARCÍA MANRIQUE, 1996: 236 y ss., 362 y ss

47 Con todo, la propuesta formal partió de la Facultad de Derecho. En junta de 13 de enero de 1954, había propuesto a Cicu, Verdross, Battaglia y Kelsen. En junta de 28 de abril de 1954 se añadieron CaRNELUTTI y MOSSA.

48 Cfr. VerdRoss, 1955, 1948. Vid. también el artículo que le dedicó a KELSEN en el homenaje por su noventa cumpleaños (VERDROSS, 1971). 
No hace falta decir que la filosofía del derecho que se impuso en el periodo posterior a la guerra civil fue el iusnaturalismo católico tradicional, que vino a cumplir un papel estelar en la tarea de justificación del Nuevo Estado y lo hizo aglutinando a los distintos grupos y clientelas que convivían en el magma ideológico del franquis$\mathrm{mo}^{49}$. Los nombres de la iusfilosofía oficial del régimen fueron L. LEGAZ (Rector de Santiago), E. Luño Peña, M. SAncho Izquierdo (Rector de Zaragoza), M. PuigDOllers, J. CorTS Grau (Rector de Valencia), W. GonZÁlez Oliveros (profesor en Salamanca)... ${ }^{50}$ Los principales representantes de la filosofía jurídica del tiempo de la república se vieron condenados al exilio o la depuración: L. RECASÉNS, J. MEDINA, B. RAmos, A. MENDIZÁBAL y F. GONZÁLEZ ViCÉN. RuIZ GiméNEZ pertenece a la siguiente hornada (más que generación) de catedráticos de Filosofía del Derecho con la que se cubrieron los «huecos» así dejados ${ }^{51}$. A partir de 1945 el grado de fascistización de la disciplina decayó al ritmo que imponía la nueva situación internacional y ello permitió que la ortodoxia católica obtuviera la completa hegemonía intelectual. Hasta finales de los años 50 la filosofía jurídica en España se estanca en un periodo de autarquía intelectual e involución. Sólo avanzada la década siguiente comenzará a experimentar movimientos de apertura y renovación ${ }^{52}$.

En este panorama la elección de KELSEN para una ceremonia tan ideológicamente cargada como la del Centenario salmantino resultaba, como digo, bastante insólita. La iusfilosofía oficial del régimen era, por supuesto sumamente hostil a su doctrina por positivista, liberal y si faltaba algo por atea. También, claro, por venir su prestigio e influencia desde la época de la República y asociada además al Tribunal de Garantías

49 Cfr. RivaYA, 1996 y 1998. Este último autor acierta al hablar de «franquismo iusfilosófico» (2010: 135), pero no parece demasiado afortunada la aseveración de que el iusnaturalismo «se pondría de moda» tras la guerra (p. 117). GARCÍA MANRIQUE, 1996: 67 y ss., 189 y ss., subraya con exactitud el carácter netamente reaccionario y conservador del iusnaturalismo hegemónico tras la guerra, en la medida en que aquello que lo volvía homogéneo, y lo aislaba de otros iusnaturalismos europeos, era justamente la actitud política antidemocrática y antiliberal. DELGADO PINTO describe la filosofía del derecho española de la posguerra como «un yusnaturalismo de inspiración tradicional, en gran medida premoderno», a través del cual «el bando triunfante impuso una cierta "concepción del mundo" de la que formaba parte la pretensión de una cultura nacional propia, que enlazara con la tradición de los siglos imperiales, y no estuviera contaminada con las modernas corrientes foráneas», DELGado PINTO, 2002: 104-105.

50 PUIGDOLleRS y SANCHO IZQUIERDO tuvieron responsabilidad directa en las depuraciones universitarias. GONZÁLEZ OlivEROS presidió los tribunales represores de la posguerra (RIVAYA, 2010: 136 y ss.).

51 Tal es la elocuente expresión que usará P. LAín en 1955 al hablar de «los numerosos huecos producidos por nuestra Guerra de Liberación en el mundo intelectual», los cuales serían llenados por los vencedores a lo largo de la década de los años cuarenta («Informe respecto a la situación espiritual de la juventud española», diciembre 1955, apud MESA, 1982: 49). Entre 1945-1950 se dotaron un número tan elevado para la época y el tamaño del gremio como siete cátedras de Filosofía del Derecho (E. Goméz Arboleya, R. PEREz Blesa, F. Elías de Tejada, J. Ruiz Giménez, E. Galán y Gutiérrez, S. Lissarrague y A. Truyol). No hubo más oposiciones hasta 1957 (A. DE Asís) y 1960 (J. Delgado Pinto y M. Hurtado). Truyol, Lissarrague y GÓMEZ-ARBOLEYA abandonaron la disciplina. GONZÁLEZ ViCÉN regresó en 1946 y se mantuvo apartado en un «exilio interior» en La Laguna.

52 García Manrique/Rivaya (1998). El iusnaturalismo tradicional «ya en la segunda mitad de los cincuenta y en los sesenta, se mantuvo más bien por inercia y a la defensiva», de forma que la transformación de la filosofía jurídica «se extendió a lo largo de unos veinte años, desde la mitad de los años sesenta hasta los primeros ochenta», apunta DELGADO PINTO, 2002: 106-107. Como escribe ATIENZA, quienes más contribuyeron a la «normalización» académica de la filosofía jurídica fueron E. DíAZ (en Madrid, vinculado precisamente a J. Ruiz-Giménez) y J. R. CApella (en Barcelona, vinculado a M. SACristán). M. AtienZA, «La Filosofía del Derecho en los países de habla española», inédito, 3. 
Jurisdiccionales instituido en $1933^{53}$. Hasta una autoridad indiscutible del régimen como LEGAZ —-teórico del «fascismo español» de la primera hora ( $c f r$ r. LÓPEZ GARCÍA, 1996) - tuvo que salir muy pronto en defensa de KELSEN ante los furibundos ataques recibidos ${ }^{54}$, sufriendo por ello generosas rociadas de «fuego amigo» (comparables, por ejemplo, a las que recibió RUIZ-GIMÉNEZ a propósito de su acercamiento a Ortega o tras la elección como catedrático de LÓPEZ-ARANGUREN en 1955). Así las cosas, nombrar a KELSEN doctor honoris causa era bastante contracorriente y no parece atribuible más que a la iniciativa de RuIZ-GiménEZ (ignoro si mediando o no la influencia de LEGAZ, algo que queda por investigar) ${ }^{55}$.

\section{PRESENTES Y AUSENTES}

Decidido que en la ceremonia de Salamanca hubiera una representación plural de doctores de prestigio internacional, no debió de ser nada fácil conseguir que se materializase. Es probable que RUIZ-GIMÉNEZ tuviera que lidiar con las múltiples dificultades que debió de plantear una ceremonia protocolaria y académicamente inédita (por la cantidad de doctores nombrados de una sola vez) y en un momento diplomático

53 Cfr. Robles, 1982: 152, 176, 193. Escribe GIL CREMADES, 1968: 14: «La “teoría pura” del derecho es en España un lugar común en los años 30». Los discípulos más importantes de KELSEN en España eran dos: uno exiliado (RECASÉNS) y otro integrado en el régimen tras una deriva hacia el fascismo (LEGAZ). RECASÉNS estudió con KELSEN en Viena en 1927 y lo tradujo al español ya en 1928 (KELSEN, 1928). LEGAZ estuvo igualmente en Viena en 1930 (el último año de KELSEN en Viena), con carta de recomendación de RECASÉNS, e hizo su tesis sobre la teoría pura, bajo la dirección de A. MENDIZÁBAL, tomista que se había opuesto al alzamiento (LEGAZ, 1933). KELSEN tuvo más relación con RECASÉNS, con quien se encontraría en México en 1960 ( $c f r$. RECASÉNS, 1974), aunque LEGAZ contribuyó a difundirlo en nuestro país ya desde antes de la guerra, traduciendo también obras capitales suyas, entre ellas la primera versión de la teoría pura, y también sus obras sobre teoría del Estado y la democracia (KELSEN, 1934; 1935a), «justo cuando la República democrática española estaba siendo puesta en cuestión» (RIVAYA, 2000: 155).

54 Cfr. LEgAZ, 1942 y 1957. En el primer texto escribía: «El "liberal” pensamiento kelseniano no difiere sustancialmente en nada de lo que afirma el pensamiento jurídico nacionalsocialista cuando quiere fundamentar, por ejemplo, la subsistencia de una “justicia administrativa” en el Estado popular alemán» (LEGAZ, 1942: 372). En el segundo sus argumentos defensivos resultan muy confusos cuando no abiertamente contradictorios. Pues por un lado reconoce que la presencia de KELSEN fue visible sobre todo en la discusión acerca del republicano Tribunal de Garantías Constitucionales y que, fuera de ello, en conjunto su influencia «ha sido bastante débil» (aunque no olvida que Primo de Rivera lo invocaba en el Parlamento, y LEGAZ mismo publicó en 1939 un texto titulado «La Teoría pura del Derecho y el pensamiento político de José Antonio Primo de Rivera»: [LEGAZ, 1947]). Mientras que, por otro lado, cita como «esfuerzo para reinstaurar en España un Estado de Derecho» el derecho a la seguridad jurídica reconocido en el Fuero de los Españoles, «consistente en el reconocimiento de un sistema jerarquizado de normas que no pueden ser alteradas arbitrariamente». Parece que más bien LEGAZ está invirtiendo de forma interesada los términos de la influencia real de KELSEN en España antes y después de la guerra. Esas últimas palabras citadas suenan, dicho sea de paso, parecidísimas a cierta parte del discurso que FRANCO dio al recibir el doctorado en Salamanca: «Es menester que, además del conocimiento de la razón histórica de nuestras leyes y del adiestramiento de nuestras juventudes para el ejercicio profesional, se inculquen dos sentimientos fundamentales: el del respeto a la seguridad jurídica, es decir, a la jerarquía ordenada de las normas de que habla nuestro Fuero de los Españoles, que todo español se sienta protegido por un orden jurídico firme y que este orden lo hagan cumplir seria y objetivamente los órganos de la Administración de Justicia».

55 Legaz estuvo presente en la investidura doctoral de Franco (VII Centenario. Programas de actos. Invitaciones. Protocolo. Alojamiento, AC 7566/2). No hay que descartar tampoco la posible influencia de VERDROss, quien había acudido a la citada Asamblea de Universidades Hispánicas como delegado de la Universidad de Viena, de la que era rector, y mantenía una relación muy cercana con Salamanca a juzgar por la correspondencia que se conserva en el archivo universitario. 
tan delicado. Surgen algunas preguntas inevitables: ¿Por qué precisamente diecinueve doctores honoris causa? ¿A qué respondía una cifra tan poco redonda (incluso si el de FRANCO contase doble por ser «de calidad»)? Sobre todo: ¿por qué finalmente la ceremonia sólo se celebró con diez doctores (además de FRANCO), una cifra mucho más redonda pero que casi dividía el número a la mitad y, por tanto, venía de algún modo a ensombrecerla? ¿Por qué dejaron de acudir en número tan elevado los doctores inicialmente propuestos? ¿Cómo se explica que ninguno de los juristas de renombre que fueron designados en un principio estuviese finalmente presente en la ceremonia? Porque los juristas no sólo eran mayoría en el total de doctores sino también en el de ausentes (faltaron CiCU, CARNELUTTI, BATTAGLIA, VERDROSS y KELSEN). ¿No resultaba todo ello extraordinariamente anómalo?

Cabe conjeturar — porque nos faltan pruebas directas (o yo no he sabido encontrarlas todas) - que hubo en efecto sorpresas e imprevistos a la hora de llevar a cabo la ceremonia con la nómina prevista de doctores y que fueron necesarios reajustes e improvisaciones de último momento. Sólo así se explica que los dos únicos juristas investidos en persona fueran incomparablemente de menor fuste que los proclamados in absentia $^{56}$. Los propósitos propagandísticos del evento eran visibles en la distribución por nacionalidades de los doctorandos propuestos: Alemania (5 doctores, dos de ellos flamantes premios Nobel), Italia (4 doctores) ${ }^{57}$, Portugal (3 doctores), Estados Unidos (2 doctores), Francia ${ }^{58}$, Austria, Venezuela y Perú (1 doctor). Sin embargo, la distribución efectiva en el acto final fue: Alemania (3) ${ }^{59}$, Portugal (3), y Francia, Italia, Perú y Venezuela (1). Los candidatos académicamente más consagrados no acudieron: entre ellos los dos brillantes Nobel (ALDER y STAUDINGER), lo que tuvo que ser vivido como

56 En efecto, de los juristas propuestos en un principio por la Facultad de Derecho sólo el iusprivatista L. Mossa se mantuvo. Y J. R. MendozA, penalista de la Universidad Central de Caracas, que fue añadido después (es decir, no fue ni siquiera propuesto por la Facultad), manifiestamente no parecía ostentar méritos en absoluto para una distinción de semejante rango (¿`se le incluyó a última hora para redondear la nómina y disimular como se pudiera las clamorosas ausencias sobrevenidas?).

57 Uno de ellos, Cicu, vinculado al fascismo. Los otros (BATTAglia, CarnelutTi, Mossa), que mantuvieron mayor distancia con éste, eran de orientación católica tradicional. CARNELUTTI había fundado con Capograssi la Unione Giuristi Cattolici Italiani.

58 El lingüista francés Michel Lejeune, de solamente cuarenta y siete años, era coetáneo y colega helenista del rector TOVAR (participó, por ejemplo, en el Homenaje a Antonio Tovar ofrecido por sus discípulos, colegas y amigos, Madrid, Gredos, 1972). Sabemos que su propuesta levantó suspicacias a la hora de ser oficialmente autorizada en el Ministerio de Asuntos Exteriores: en el oficio de respuesta que éste emite el 10 de abril de 1954 se hace constar que La Sorbona «desde 1936 hasta la fecha, no ha considerado oportuno otorgar distinción semejante a ningún profesor de la Universidad española» y «ha puesto especial cuidado en el periodo 1936/1954 en no invitar oficialmente para profesores en sus cursos públicos a ningún estudioso ni profesor español [...] En cambio, los profesores SÁNCHEZ-AlbORNOZ, AMÉRICO CASTRO y otros en exilio han sido recibidos oficialmente por la Sorbona» (VII Centenario. Mensajes de participantes, AC 7565/5). Esto demuestra, por lo demás, que los candidatos propuestos desde Salamanca debían recibir aprobación desde Madrid: en ese mismo oficio, después de declarar que «no hay inconveniente alguno para la investidura de los Catedráticos alemanes que se mencionaban en la lista adjunta», se procede a dar el visto bueno a CICU, BATTAGLIA y BASTOS MONTEIRO.

59 De ellos el más relevante sin duda era L. WAGNER, de setenta y cuatro años, uno de los romanistas más importantes del siglo XX. HENGLEIN, de sesenta y un años, era director del instituto de Química Técnica de Karlsruhe. En cambio, el mayor mérito de Adolf DABELOW, doctorando honoris causa por Medicina, de cincuenta y cinco años, parece haber estribado en ser rector de Maguncia si no contamos el de haber sido nazi: perteneció al NSDAP y a las MF-SS y fue uno de los firmantes de la declaración de profesores alemanes en apoyo a HitLER (la tristemente célebre Bekenntnis der Professoren an den deutschen Universitäten und Hochschulen zu Adolf Hitler und dem nationalsozialistischen Staat, presentada el 11 de noviembre de 1933 en Leipzig). 
un importante deslucimiento del evento. Sólo en un caso la ausencia se explica por razones de edad: el del ya citado hispanista A. M. HunTingTON ${ }^{60}$. Por otro lado era llamativa la ausencia de juristas que habían sido depuestos de sus cargos por el nazismo (KELSEN y VERDROSS) o se habían opuesto al fascismo (MOSSA) ${ }^{61}$, y cuya propuesta (según hemos sugerido) se debía a los oficios conciliadores de RUIZ GimÉNEZ. Parece que lo que inicialmente se planeó como una representativa y prestigiosa muestra de académicos extranjeros de prestigio ${ }^{62}$, terminó siendo un nombramiento básicamente de rectores (cinco en total) ${ }^{63}$, con los que ya se tenía contacto en Salamanca a raíz de la citada Asamblea de Universidades Hispánicas del año anterior, y de los que tuvo que echarse mano como «comodines» para cubrir las ausencias.

Uno de los pocos indicios documentales que tenemos de la preocupación existente en la organización del acto ante posibles ausencias o el fiasco de una falla masiva es el meticuloso control y recuento que se hizo por escrito de las diferentes respuestas que iban recibiéndose de los profesores propuestos. En el Archivo de la Universidad obra el documento titulado Doctores Honoris Causa propuestos por esta Universidad para ser investidos en los actos de Clausura del VII Centenario, donde se totaliza el listado definitivo de candidatos con los que iba a darse por cerrada la ceremonia ${ }^{64}$. A continuación, se clasifican los candidatos ausentes indicando quiénes no asistirán y quiénes están pendientes de respuesta. Por la Facultad de Derecho aparecen incluidos entre lo primeros CICU, BATTAGLIA y VERDROSS, pero a continuación figura añadida a mano la palabra «KELSEN» (así, sin nombre de pila) y la indicación de su universidad («U. de California, Berkeley, U.S.A.»). Entre los segundos («propuestos, pero pendientes de respuesta») figura CARNELUTTI. Según esto, KELSEN sería de los que confirmaron su aceptación pero también su no asistencia al acto. Eso concuerda con el telegrama al que ya hicimos mención anteriormente. Pero ya hemos dicho que no hay evidencia directa de ninguna de ambas cosas (que KELSEN aceptara el nombramiento y excusara su inasistencia) fuera de la copia mecanografiada de dicho telegrama ${ }^{65}$.

60 Huntington era el fundador de la Hispanic Society of America de Nueva York, y el único no académico del panel. Su propuesta parece puramente simbólica ya que contaba ochenta y cuatro años y era muy previsible que no pudiera acudir a la ceremonia desde Estados Unidos (de hecho murió el año siguiente).

61 Mossa se había pronunciado públicamente a favor de la derogación de los códigos fascistas, especialmente el código civil, en polémica con gran parte de la doctrina italiana.

62 En una «Minuta para un oficio del Rector a los Decanos de las cuatro Facultades» (VII Centenario. Asuntos Generales, AUSA 13406/13, sin fecha) se pide a cada una de éstas que proponga a «dos profesores extranjeros».

63 Éstos eran: Battaglia, Correia, Dabelow, Delgado y Verdross. El primero de ellos, según se desprende de la correspondencia obrante en el archivo, tuvo que abandonar Salamanca precipitadamente justo antes de la investidura (lo que tal vez dio ocasión a redondear a diez el número final de doctores presentes). Tampoco acudió VERDROSS.

64 Programas de actos. Invitaciones. Protocolo. Alojamiento, AC 7566/2, sin fecha. En él, sobre un primer total de ocho profesores, se añade a mano la anotación de los nombres de los portugueses CARVALHO y CORREIA (ambos de Coimbra, y ambos asistentes a la Asamblea de 1953), de donde parece inferirse que éstos fueron incluidos al final para redondear la cifra definitiva a diez.

65 No existe constancia de ninguna comunicación escrita de KELSEN en tal sentido ni en el Archivo de la Universidad de Salamanca, ni en del Ministerio de Educación, ni en el Archivo General de la Administración, ni en el Hans Kelsen-Institut. Acaso se trató, pues, de una comunicación telefónica, puesto que en el archivo salmantino se conserva gran cantidad de los telegramas originales recibidos con ocasión de los actos del Centenario. 
El hecho de que esa anotación sea un añadido manuscrito indica que la decisión de incluir a KELSEN en el grupo de quienes aceptan el nombramiento como doctores bonoris causa fue no sólo sobrevenida sino de ultimísima hora. Implica, por tanto, un largo periodo en el que subsistió la duda de si aceptaría o no. Finalmente parece que KELSEN decidió aceptar. Pero la cuestión es si fue una decisión que arrancó enteramente de KELSEN... o también intervino en ella la propia Universidad. En efecto, es probable que su nombre fuera incorporado a ese listado en un último recuento inmediatamente próximo a la fecha de la ceremonia ${ }^{66}$. Pero no es probable que el hecho que motivó esa incorporación fuera una eventual comunicación escrita de respuesta de KELSEN (que no conocemos, como tampoco la hipotética carta de comunicación formal del nombramiento y consiguiente invitación ${ }^{67}$. En cualquier caso, lo que sí resulta indudable es la necesidad apremiante que en el momento de confeccionar el listado tenía la Universidad de clarificar la posición de KELSEN, no tanto sobre si acudía al acto de Salamanca (la inminencia de la fecha descartaba ya esta posibilidad), sino sobre si aceptaba ser nombrado en ausencia, pues se trataba de disimular a toda costa cualquier desaire fatal para una ceremonia tan políticamente calculada como aquella.

\section{EL SILENCIO DE KELSEN}

Si realmente hubiera habido contestación en tiempo y forma por parte de KELSEN, y esta fuera positiva (si hubiera aceptado de forma expresa recibir la alta distinción académica salmantina, incluso excusando su asistencia), ¿por qué no estuvo incluido desde el principio en la segunda categoría — junto con CiCU, BATTAGLIA y VERDROSSy hubo de ser adicionado posteriormente a mano? No se le preguntó por escrito (como a su compatriota HuNTINGTON) si aceptaba ser investido doctor honoris causa en ausencia, ni se le ofreció la posibilidad de ser investido en una ceremonia presencial posterior (como se hizo con STAUDINGER ${ }^{68}$ ), ni la universidad no tomó de oficio entonces, en 1954, la iniciativa de enviarle el título acreditativo por vía diplomática ${ }^{69}$, en vez de ser el propio KELSEN quien tuviera que iniciar la gestión al efecto dos años después. La única explicación plausible es que su respuesta fue muy tardía y vino precedida de un largo silencio que indujo a pensar que KELSEN no iba a aceptar el nombramiento como doctor honoris causa. Ello permitiría entender por qué KELSEN no figuraba entre los «propuestos pero pendientes de respuesta» (como CARNELUTTI). Sencillamente: porque se interpretó desde Salamanca su silencio en efecto como negativo. A diferencia del caso de otros candidatos, había más razones para que esta duda fuera interpretada como una tácita negativa. KELSEN era un académico de «calado ideológico», un filóso-

66 Como también parece suceder en los otros dos casos: el de CARVALHO y, sobre todo, el del rector de Coimbra, CORREIA, añadido en el último momento, quizá en sustitución de BATTAGLIA.

67 Esta no se conserva de ninguno de los doctores bonoris causa propuestos, aunque sí algunas de las respuestas.

68 El flamante Nobel de Química de la Universidad de Friburgo acudió personalmente el 14 de marzo de 1955 a una ceremonia especialmente celebrada para ello (Memoria correspondiente al Curso Académico de 1953-1954. Actividades académicas del de 1954-55, Salamanca, Talleres Gráficos Núñez, 1955, 47; ABC, 17 de marzo de 1955).

69 Como ya se mencionó, el embajador AREILZA escribe al rector una carta (el 18 de octubre de 1955) a este propósito, donde le dice que hará llegar a HunTINGTON el diploma (AC 17628/7). 
fo del Derecho y del Estado que defendía la democracia liberal, un alemán refugiado en Estados Unidos que había huido del nazismo. Su omisión sólo podía ser entendida, en definitiva, como militante. Por eso a KELSEN no «se le escribió pidiendo aclaración» (tal como sí se hizo con HunTiNGTON, según consta en el documento antes mencionado): ésta no hizo falta. Solamente unos pocos días antes de la ceremonia se le llamó por teléfono desde Salamanca para asegurar que no rechazaba su investidura in absentia ni la desautorizaría posteriormente.

Si la interpretación anterior es correcta, KELSEN rehusaba con su postura inicial de silencio aceptar el doctorado bonoris causa de Salamanca. De ese modo se excluía tanto de la ceremonia presencial como del panel final. Sólo la llamada (tal vez tensa) desde Salamanca, ya encima el acto de investidura, puso fin al silencio demandándole una respuesta «a bocajarro». Y fue entonces cuando KELSEN dijo que sí. Un sí que ya no podía ir referido a su investidura en presencia (y de ningún modo es congruente con la «aceptación complacidísima» relatada en la carta de MESA-MOLES). Entonces en Salamanca se pudo respirar de alivio: después de haberlo dado por «perdido» para la causa, se procedió a incluirlo (de la forma artesanal que exhibe el citado documento) entre los aceptantes del doctorado honoris causa como si efectivamente lo hubiera aceptado de forma expresa desde un inicio, y finalmente fue «proclamado en ausencia» en la ceremonia del 10 de mayo, tal como relata la Memoria, proclamación que consistió en la lectura de su nombre como parte de la lista total de los 18 doctores. La respuesta de KELSEN hubo de ser recibida sin duda como un éxito: de ahí el telegrama enviado al Ministerio. Seguramente KELSEN se había convertido en un incómodo problema, por su especial simbolismo: quizá no el único problema, desde luego, pero sí uno muy relevante. Pero todo esto significa también que la inclusión final de KELSEN tuvo un importante elemento propagandístico y se produjo en alguna medida mediatizando su propia voluntad. En alguna medida: no en toda, obviamente, pues KELSEN a fin de cuentas aceptó. Pero su nombre no dejó de ser en cierto modo instrumentalizado en Salamanca.

Aunque la investigación detectivesca de la intrahistoria de la ceremonia salmanticense - la interpretación abductiva de sus diversos «hechos negativos»- tiene bastante de especulativa a falta de más evidencias, y es por ello un asunto que permanece abierto para historiadores y estudiosos, la expuesta me parece la más verosímil reconstrucción de los datos positivos de que disponemos. KELSEN omitió aceptar su nombramiento como doctor honoris causa por la Universidad de Salamanca. Simplemente no contestó a la propuesta y dejó correr el tiempo, mirando para otro lado y manteniendo esta omisión hasta el último momento, cuando fue interpelado. La otra interpretación posible (que no puede refutarse, pero sigue siendo un probandum) es que KELSEN aceptase el nombramiento por escrito desde un principio excusando el no poder desplazarse (tal como dice MESA-MOLES en su carta al secretario de Salamanca). Pero incluso entonces tal respuesta debió de ser igualmente muy tardía y había dado lugar ya a su descarte por inacción (como muestra el modo en que se clasificó su caso en el documento anterior). Si KELSEN hubiera aceptado expresamente y a tiempo la propuesta, las justificatorias palabras de MESA-MOLES habrían sido innecesarias. Además, el régimen habría hecho uso de su figura de una manera muy distinta (aunque dado el tibetanismo universitario del momento tal vez incluso esto era pedir demasiado). 
En cualquier caso, si resultan dudosas las circunstancias en que KELSEN aceptó el nombramiento salmantino (fuera expresa o tácitamente), lo que resulta indiscutible es que no lo rechazó expresamente. La pregunta fundamental ahora es: ¿debió haber declinado formalmente la propuesta cuando fue hecho conocedor de ella en 1953-1954? En mi opinión es innegable que sí: que eso era lo debido habida cuenta de su posición, su trayectoria y su circunstancia. ¿Por qué no lo hizo? ¿Fue por ignorancia acerca de la situación de Salamanca y en general de España? ¿Se limitó a separar la ciencia de la política? ¿Hubo alguna otra razón? Si existió instrumentalización de su figura por parte del régimen franquista, ¿contribuyó KELSEN pasivamente a ella con su silencio inicial y su aceptación final por más que ésta fuera diferida?

El hecho cierto es que en 1956, dos años después, KELSEN cambia su actitud y reivindica el título de doctor bonoris causa. Con ello quiso transformar quizá su silencio previo de negativo a positivo: así se deduce al menos de la carta de MESA-Moles. La borrosidad burocrática de la condición de «doctor honoris causa» se prestaba desde luego a ello: ¿cuándo pasa uno a poseer tal distinción: al ser propuesto o al ser nombrado? ¿la investidura es «constitutiva» o meramente «declarativa»? ${ }^{70}$, ¿lo era la «proclamación en ausencia»? Tal es justamente la cuestión que KELSEN planteará en 1956 en su consulta al secretario de la Universidad de Granada y que éste trasladó a Salamanca. Tuvo que ser una gran sorpresa, y muy agradable para algunos, recibir en la Universidad aquella carta desde Granada informando del redivivo interés de Hans KELSEN por formar parte de su claustro. De ahí que se le contestara y se pusieran en marcha (o al menos se anunciaran, pues ignoramos si realmente lo recibió) gestiones para el envío del diploma tan rápidamente (rapidez que abona de nuevo la hipótesis del silencio negativo). ¿Por qué dio KELSEN este paso, abandonando la actitud de distancia o prudencia que había mantenido hasta entonces (incluso habiendo aceptado al final ser incluido en el acto)? ¿Vino con ello de algún modo a convalidar volens nolens aquella pieza maestra del género megalomaníaco-académico que fue el doctorado bonoris causa de FRANCO? Sobre todo: ¿supuso dar un espaldarazo a la ejecutoria del régimen político español, un régimen inequívocamente totalitario? ¿Necesitaba realmente KELSEN un título de esa significación y a ese precio? Sólo nos queda tratar de dar respuesta a estos interrogantes a la luz de su propia biografía.

\section{SALAMANCA (Y ESPAÑA) DESDE BERKELEY}

Sabemos ya cómo pudo ser percibido KELSEN desde Salamanca en el momento de ser propuesto para el doctorado honoris causa: un jurista de talla universal, cuya escuela había sido de referencia en la República, un teórico del liberalismo y la democracia

70 Parece que la sola propuesta (salvo que sea rechazada formalmente por el candidato) tiene ya en sí misma una cierta dimensión constitutiva, dado el significado honorífico que comporta, con independencia del acto formal de la investidura. Proponer a alguien para ser nombrado doctor honoris causa ya es un reconocimiento (en cierto modo un nombramiento), que posteriormente viene a ser declarado en el acto de la investidura o proclamación. Si ésta no se da, parece que la mención subsiste. La prueba de ello es que tiene que ser retirada expresamente si se considera que ese merecimiento honorífico ha cesado (el caso de FRANCO es el mejor ejemplo, pero en la España de los últimos años — y también en la Universidad de Alicante- conocemos también algún caso muy notorio). 
muy crítico con el «derecho natural», un exiliado europeo del nazismo, un ciudadano americano que, como HuNTINGTON, merecía un trato especial dada la coyuntura internacional... Ahora bien: ¿qué percepción podía tener KELSEN del acto de Salamanca en 1953-54 cuando se le hizo llegar la propuesta ${ }^{71}$ ? ¿Llegó a tener conocimiento de que FRANCO también recibiría esa distinción en el mismo acto? ¿Fue consciente del significado político del evento?

KELSEN tenía entonces 72 años. En 1954 hacía dos que se había jubilado como profesor de la Universidad de California en Berkeley, donde desde 1943 estaba instalado de modo permanente tras un breve paso por la Harvard Law School (1940-1942). A Estados Unidos había emigrado desde Ginebra, tras verse obligado a abandonar Europa en 1940, recién comenzada la guerra, huyendo del avance de HiTLER.

A esas alturas de su vida, su prestigio intelectual era muy sólido (mucho más, desde luego, que su situación económica ${ }^{72}$. KELSEN era un jurista consagrado que había recibido importantes honores de las más prestigiosas universidades internacionales. En 1953 contaba ya cinco doctorados honoris causa: Utrecht (1936), Harvard (1936), Chicago (1941), México-UNAM (1951) y la propia Berkeley (1952). Había sido además nombrado Honorarprofessor de la Universidad de Viena (la cual lo había desagraviado y rehabilitado en 1947), Profesor honorífico de la de Río de Janeiro (1949) y Professor Emeritus de Berkeley (universidad que, posteriormente, en 1964 dio su nombre a la biblioteca del Departamento al que perteneció) ${ }^{73}$. A estas menciones se sumaba abora el doctorado bonoris causa de Salamanca, una de las cuatro universidades más antiguas de Europa, que conmemoraba su centenario.

Es claro que si algún motivo podía excusar la inasistencia de KELSEN a Salamanca no era su dificultad o imposibilidad para viajar. En realidad ahora comenzaba el periodo de su vida en que comenzaba realmente a viajar. Hasta este momento, su azarosa vida había sido la de un expatriado itinerante que, ligero de equipaje, había tenido que recalar ya en varios destinos (ALARCÓn, 2012). En Austria comenzó su carrera académica como profesor en la Universidad de Viena en 1911 y permaneció hasta 1930. De aquí pasó a la Universidad de Colonia (1930-33), donde en abril de ese último año fue depuesto de su cargo de Decano de Derecho (junto con HeLLER, KanTOROwicz y LOEWENSTEIN) cuando el partido nacionalsocialista tomó el poder. Viajó entonces a Suiza, donde dio clases en el Institut Universitaire de Hautes Études Internationales de Ginebra y en Zurich. En 1936 se trasladó a la Universidad Alemana de Praga, su ciudad natal, después de haber considerado una oferta de la London School of Economics de Londres y de tentar la posibilidad de incorporarse a diferentes universidades

71 Recordemos que fue propuesto formalmente por la Facultad de Derecho de Salamanca en enero de 1953. La comunicación tuvo que tener lugar entre esa fecha y principios del año siguiente.

72 Esta no era en absoluto boyante pues su pensión de jubilación en Berkeley distaba de ser cuantiosa y debía complementarla con otras actividades (elaboración de dictámenes, dictado de charlas y conferencias como profesor invitado, labores de asesoría, etc.). Un año después de su jubilación, en 1953, la Universidad de Colonia después de un «procedimiento de rehabilitación» (Wiedergutmachungsverfahren) lo nombró profesor emérito, con lo que la cuantía de su pensión pudo actualizarse con los atrasos de los casi treinta años de servicios prestados tanto en Austria como en Prusia que los nazis le habían expropiado. Cfr. OLECHOWSKI, 2011: 17.

73 Se trata de la Hans Kelsen Graduate Social Science Library, del Department of Political Science. Vid. la nota publicada por el Decano de la Facultad de Derecho de Berkeley al fallecimiento de Kelsen en 1973: HALBACH Jr., 1973: 959. 
estadounidenses. En la ciudad que le vio nacer estaba cómodo, pero la envenenada situación política le forzó a abandonar el país después de sólo tres semestres, al cabo de los cuales regresó a Ginebra. Finalmente en 1940 emigró a Estados Unidos ${ }^{74}$, donde ya hemos dicho que hubo de viajar de costa a costa.

Por tanto, alcanzado el emeritazgo en Berkeley en 1952, KELSEN por fin contemplaba, al comenzar su séptima década de vida, un destino que podía pensar como ya último y definitivo. Es frecuente repetir el dato de que es aquí donde por primera vez en su vida - a los 65 años- se compra una casa ${ }^{75}$. Las frases con las que concluye su Autobiografía de 1947 expresan el sentimiento de interinidad finiquitada que le invadía (y que con todo no abandonaba la cautela de un «probablemente»), en una de las poquísimas licencias líricas que KELSEN se permitió por escrito ${ }^{76}$.

Eso no significa, sin embargo, que a partir de entonces KELSEN se abandonara a la muelle tranquilidad del sedentarismo. Por el contrario: como decía, ahora podía elegir viajar y de hecho lo hizo con mayor frecuencia que nunca. Viajó a diversos lugares de Estados Unidos y Canadá varias veces para dictar cursos y conferencias. Planeó incluso un viaje a Viena que finalmente fue cancelado (lo mismo que un ciclo de conferencias previsto en México en 1947) (MÉTALL, 1976: 87); FlORES, 2014: 58). Emprendió una agotadora gira latinoamericana en la que en 1949 recorrió durante 67 días más de 20.000 kilómetros por Argentina, Brasil y Uruguay, abriendo lo que ha sido bautizado como «el frente sur» de la Teoría pura del derecho (SARLO, 2010). Pero desde 1952-1953 intensificó su actividad transatlántica con frecuentes viajes a Europa. En primer lugar a Ginebra, ciudad que amaba, donde fue invitado nuevamente como profesor visitante por el Institut Universitaire de Hautes Études Internationales gracias a una subvención de la fundación ROCKEFELLER, «que siempre se había mostrado muy complaciente con KELSEN» (MÉTALL, 1976: 91). De ahí viajó a La Haya para impartir un ciclo de conferencias en la Academia de Derecho Internacional. Regresó a Estados Unidos para permanecer por un año en Newport como profesor invitado del Naval War College. En 1953 dictó unos cursos en el Colegio de Europa de Brujas invitado por G. ARANGIO-RUIZ ${ }^{77}$.

No resulta demasiado verosímil, por tanto, el supuesto de que KELSEN careciera realmente de la posibilidad de viajar a Salamanca por esas fechas (aunque, de nuevo, tampoco es totalmente descartable). Sabemos también que en abril de 1954 el Institut de Droit International lo acogía como miembro honorario (a propuesta de A. VERDROSS, su vicepresidente) en su sesión 46. ${ }^{a}$ celebrada en Francia, en Aix-en-Provence muy cer-

74 Por cierto que en su salida de Ginebra pasó por España: Granada no sería su primera estancia en nuestro país. Hizo escala en Barcelona antes de partir desde Lisboa el 28 de mayo de 1940 en dirección a Nueva York adonde llegó el 21 de junio a bordo del SS Washington (NITSCH, 2009: XXVIII).

75 MétAlL, 1976: 84. Es uno de los pocos datos privados que KELSEN comunica en su Autobiografía (KELSEN, 2008: 172). La compra sólo fue posible tras ser nombrado full-time professor en 1945 (pero no se confirmó sino en 1948 que su contrato se prolongaría hasta la jubilación a los 70).

76 «Mientras redacto estos recuerdos he llegado a los 66 años de edad. A través del amplio ventanal, junto a donde se encuentra mi escritorio, observo más allá de los jardines la bahía de San Francisco y el puente Golden Gate, tras el cual fulgura el océano Pacífico. Aquí será probablemente el "postrer sitio de reposo del cansado caminante” »(KELSEN, 2008: 172-173). La referencia final es al poema de HEINE ¿Dónde? colocado en su lápida del cementerio parisino de Montmartre.

77 Cfr. ARANGIO-RUIZ/JimÉNEZ DE ARECHAGA/SCHACHTER, 1998: 386 (se trata de extractos de entrevistas realizadas a estos internacionalistas por A. CASSESE en 1996, 1993 y 1995 respectivamente). 
ca de la frontera española ${ }^{78}$. Esta circunstancia, que motivaría su presencia en Granada dos años después, sucedía del 22 de abril al 1 de mayo: apenas una semana antes del día previsto para la investidura doctoral salmantina (10 de mayo). KELSEN tenía una magnífica ocasión, por tanto, para acudir a recoger en un mismo viaje ambos reconocimientos honoríficos, dos más de los muchos que merecidamente estaba recolectando por diferentes países de Europa y América. La distinción de la universidad de Salamanca era además importante para él: la prueba de ello es el interés que mostró después por recobrarla. Si no acudía tenía que ser por alguna razón igualmente importante.

Es plausible que esa razón tuviera que ver con la situación política de España, tal como era percibida por KELSEN y —-sobre todo- por los Estados Unidos, su nueva patria. Vamos a comprobar hasta qué grado la perspectiva de KELSEN pudo verse determinada por la perspectiva del país norteamericano del que era ciudadano.

En efecto, la nueva coordenada vital y política de KELSEN era Estados Unidos, potencia victoriosa de la segunda guerra mundial. Sabemos por su propio relato y por distintos estudios biográficos lo duro que fue para él integrarse en ese país, tanto por las circunstancias traumáticas del traslado recién comenzada la guerra como por su edad y sus escasos conocimientos del inglés ${ }^{79}$. Sufrió con una amargura que debió de ser rayana con la humillación las dificultades para encontrar un puesto académico estable allí, algo que KELSEN venía preparando desde hacía tiempo ${ }^{80}$. Desde principios de los años treinta, Estados Unidos se convirtió en un destino natural para muchos intelectuales judíos europeos, pero KELSEN además pasó a ser un temprano símbolo de ese éxodo. Su exilio de Alemania en 1933 con la llegada de HitLER a la Cancillería del Reich y su posterior peregrinaje por otros países europeos, unido al gran prestigio como jurista que ya acumulaba, habían dado a su figura un relieve especial en aquellos extremosos tiempos. Como señala ALARCÓN: «Kelsen se convertía en un modelo del libre pensador occidental que era defendido por la democracia organizada contra el totalitarismo fascista» (AlARCón, 2012: 44). Así fue visto sin duda desde Harvard ${ }^{81}$ cuando esta Universidad — a instancias de POUND, por entonces Decano de la Law School_ propuso su nombramiento como doctor honoris causa en septiembre de $1936^{82}$. KELSEN cruzó

78 Cfr. Annuaire de l'Institut de Droit International, vol. 45: Session d'Aix-en-Provence, Avril-Mai, 1954, 2 vols. (Bale, Editions Juridiques et Sociologiques S.A., 1954), vols. II, VII y IX. KELSEN fue elegido miembro honorario directamente, lo cual era excepcional. Acudió también a las dos reuniones posteriores a la de Granada (1959 y 1963).

${ }^{79}$ «Con el corazón adolorido abandoné Ginebra con mi mujer en 1940. Una ciudad donde había realizado satisfactorio trabajo durante siete años, en un ambiente ideal. Cercano a la edad de sesenta años, iba a iniciar de nuevo y desde el principio mi carrera académica, en un país cuya lengua dominaba apenas muy imperfectamente» (KELSEN, 2008: 171).

80 Información detallada de la intensa actividad epistolar de KELSEN en tal sentido en los años previos buscando posición en diferentes universidades e instituciones estadounidenses puede verse en NITSCH, 2009: IX y ss. Ya en 1938 había declarado a Roscoe Pound su intención de asentarse académicamente en Estados Unidos.

81 La emigración estadounidense afectó al menos a cinco escuelas austríacas: la de L. VON MiSES, la de K. BüHler, la de M. Adler, el «Círculo de Viena» de M. SCHLicK y la Wiener Scbule de Kelsen. Sobre la recepción en Harvard de académicos exiliados europeos, cfr. JoNES, 1984. Hay, sin embargo, estudios críticos que nos informan también del antisemitismo y las iniciales simpatías nazis del presidente de Harvard J. B. CONANT (cfr. HERSHBERG, 1993: 90 y ss.).

82 El Honorary LLD otorgado a KELSEN por la Universidad de Harvard formaba parte — también— de un centenario. En esta ocasión el tercero de esa universidad, celebrado en 1935-1936, con gran repercusión aca- 
entonces el océano para asistir al acto. Le daba una trascendencia no sólo académica sino también vital, pues estaba comenzando a ver en Estados Unidos un futuro refugio en vista de la inminencia de la guerra en Europa ${ }^{83}$.

Sin embargo, una vez que KELSEN llega a Estados Unidos con la intención de afincarse allí de modo definitivo la situación que se encuentra es muy otra a la esperada. Si nos atenemos a los archivos de la Fundación Rockefeller, la colocación de KELSEN se convirtió en un «problema difícil» ${ }^{84}$. Especialmente duro para él fue el rechazo de la Harvard Law School, no sólo porque KELSEN confiaba en encontrar acomodo definitivo allí, y por eso había aceptado la invitación de POUND y seguido sus consejos, sino porque confiaba en que el honorary degree recibido por esa universidad, que le distinguía como el más destacado jurista continental, le facilitaría efectivamente las cosas. No fue así. Después de impartir las Oliver Wendell Holmes Lectures en el año 1940-1941, sólo consiguió continuar un año más como Research Associate y al tercer año, tras impartir un curso en el puesto de Lecturer de sociología jurídica, el presidente CONANT le comunica la imposibilidad de prolongar su contrato y de proveerle una plaza definitiva. A KELSEN le afectó mucho esto ${ }^{85}$. Fue el mismo POUND quien le reco-

démica internacional (fueron galardonados figuras tan importantes como JAEGER, JUNG, MEINECKE, CARNAP, Piaget, Malinowski, Eddington, Gilson, Hazard, Gordon Childe). Kelsen impartió el 9 de septiembre de 1936 una charla titulada «Centralization and Decentralization». Fue presentado como «Professor of International Law, Institut Universitaire des Hautes Études Internationales, Geneva». Puede verse el programa completo de actos y la nómina de conferenciantes y doctorandos en The Tercentenary of Harvard College: A Chronicle of the Tercentenary Year, 1935-1936, Cambridge, Harvard University Press, 1937, 217, 459-460. Agradezco a Robin CARLAW, investigador de los archivos de la Universidad de Harvard, de la Pusey Library, el haberme facilitado la comprobación de estos datos.

83 «Al declararse la guerra en 1939, ya había tomado la decisión de abandonar Europa» (KELSEN, 2008: 168). Esa es probablemente la razón de que decidiera rechazar la oferta de ir a Londres. MéTALL, 1976: 82, nos dice que intentó también obtener el visado para algún país. Los primeros intentos de buscar un puesto en diferentes universidades americanas (Columbia, Princeton, Michigan, Chicago, Yale, Harvard) fracasan debido a las dificultades económicas y la masiva afluencia de académicos europeos («la barca está llena», era un dicho europeo del momento). La situación revestía especial complicación en ciencias sociales y sobre todo en derecho (cfr. FeichtingeR, 2009: 325 y ss.). Muchas universidades no estaban dispuestas (como le dice Pound en carta a un colega de la Universidad de Illinois) a acoger a emigrantes si había un estadounidense idóneo para el puesto, algo que, confiesa, «me temo que veremos muchas veces en el futuro próximo». Además, el Emergency Committee in Aid of Displaced Foreign Scholars se acogía al subterfugio formal de que KELSEN en rigor no era un «refugiado», ya que provenía de Ginebra (siendo así que sí había sido depuesto por los nazis en 1933) (NITSCH, 2009: XVII y ss.). Este autor hace notar también cómo KELSEN reconstruye en su autobiografía esta difícil etapa de modo «retrospectivamente condicionado».

${ }^{84}$ En una nota de esos archivos relativa a KELSEN se lee lo siguiente: «[E]specially the irrelevance of his philosophical approach when war conditions have weakened American law schools make him a difficult problem» (Rockefeller Collection, Record Group 1.1, Series 205 S, Box 24, Folder 364, citado por EHS/GASSNER, 2015). La fundación Rockefeller, no obstante, no sólo le ayudó económicamente tras su llegada a Boston (KelSEN, 2008: 70; MÉTALL, 1976: 82, 91), sino que fue la institución que hizo posible su contratación en la Harvard Law School para impartir las Holmes Lectures, ya que se comprometió a pagar la mitad (NiTSCH: 2009: XXIX-XXX). El entonces Decano, J. McCAuLEy LANDIS, se apoyó para ello en la calificación que su predecesor POUND había hecho de KELSEN como el más eminente jurista vivo (el segundo candidato era J. H. WigMORE). Las palabras exactas de POUND, sin cuya intermediación — como vemos- las cosas para KeLSEN hubieran sido muy diferentes en su etapa americana, eran: «Kelsen, now that Stammler has retired, is unquestionably the leading jurist of the time. His disciples are devoted and full of enthusiasm in every land. His ideas are discussed in all languages. His followers are probably the most active group in contemporary jurisprudence» (Pound, 1934: 532).

85 «Ese fracaso me hirió bastante, con mayor razón cuando yo, como Doctor honoris causa de la Universidad de Harvard, había esperado un mejor trato» (KELSEN: 2008: 170-1). 
mendó a la Universidad de California ${ }^{86}$, adonde llegó en 1943 como Visiting Professor del departamento de ciencia política (MÉTALL, 1976: 83-84).

Las condiciones de trabajo habían empeorado notoriamente en tiempos de economía de guerra como aquéllos. Los recortes del presupuesto de la universidad, junto con la disminución del número de estudiantes, hacían necesario a KELSEN complementar la modesta remuneración de su contrato a tiempo parcial (entre 1943 y 1945). MÉTALL escribe que KELSEN «fue llamado a Washington como asesor técnico» del gobierno (MÉTALL, 1976: 85). Sin embargo, el internacionalista Oscar SCHACHTER nos relata una anécdota personal que revela los verdaderos antecedentes de esa actividad extra de KELSEN y que resulta bastante iluminadora de su situación entonces ${ }^{87}$. A partir de ahí se convirtió también en 1945 en asesor de la Comisión de Crímenes de Guerra, preparando durante tres meses los juicios de Núremberg contra los jerarcas nazis. No tomó sin embargo parte en ellos. Tampoco participó en la conferencia de San Francisco que redactó la Carta de las Naciones Unidas (la delegación norteamericana con L. PASVOLSKY al frente, quiso darle un perfil más político que jurídico y KeLSEN fue deliberadamente excluido), aunque según MéTALL (1976: 85) varios delegados acudieron a consultarle.

KELSEN se ganó de esta forma una pequeña posición de influencia —especialmente en el segundo de los mencionados comités_- de la cual se sentía orgulloso ${ }^{88}$. Hay que tener en cuenta que, desde el punto de vista intelectual, KELSEN estaba aislado en Estados Unidos, un hecho fundamental para entender estos primeros años en el país. KELSEN estaba desconectado de la academia (por no decir que se le hizo el vacío) y sólo contaba con admiradores dentro de la comunidad de exiliados europeos ( $c f r$. Paulson, 1988: 181; Telman, 2011: 514). Los acontecimientos del final de la guerra y de la inmediata posguerra le dan ocasión para dedicarse plenamente al derecho internacional no sólo en su vertiente práctica sino también teórico-académica. KELSEN comprende que esta es una vía que le permitirá abrirse puertas y afianzarse dentro de la cultura jurídica estadounidense. Por supuesto, este campo no era nuevo para él sino que lo había cultivado extensamente en los cursos de derecho internacional impartidos durante los años treinta, sobre todo en su periodo ginebrino (1933-1940). Era de

\footnotetext{
${ }^{86} \mathrm{Al}$ parecer también L. FuLLER, profesor en Harvard, intervino en esa ayuda a KELSEN. FuLLER había ayudado también a otros juristas europeos, como Edgar BODENHEIMER (SUMMERS, 1984: 7).

87 «Siendo yo consultor jurídico de la Administración de las Naciones Unidas para el Socorro y la Reconstrucción (UNRRA) en 1944 o 1945 (ubicada en Washington), el Departamento de Personal me pidió que entrevistara a un aspirante a un empleo para el que se pedía formación jurídica. Cuando el candidato me presentó su tarjeta, dije asombrado: "Pero ¿es Ud. ese Hans Kelsen?" Entonces él contestó: “He estado buscando trabajo en Washington y Ud. es la primera persona que reconoce mi nombre". No era, desde luego, sorprendente que los abogados y funcionarios del gobierno no supieran de la eminencia de Kelsen». El superior de SCHACHTER, A. H. FELLER (director del departamento jurídico de las Naciones Unidas), no consideró apropiado «tener a Kelsen ocupado con nuestros problemas jurídicos mundanos y creyó que sería indigno para él ocupar el puesto de un bibliotecario» (ARANGIO-RUIZ et al., 1998: 389). Es de suponer, pues, que se le ofreció entonces el puesto al que MÉTALL se refiere de asesor de la Office of Wartime Economic Affair's Liberated Areas Division, organismo encargado de preparar la administración de los territorios que iban a ser liberados del dominio alemán, especialmente Austria.

${ }^{88}$ Menciona así su posición como asesor gubernamental entre sus títulos académicos en la firma de dos artículos de la época: KELSEN, 1945a, donde se presenta como «Special Assistant in the United States Department of State, 1942-1945», y KELSEN, 1945b, donde lo hace como «Consultant to the War Crimes Office of the War Department».
} 
hecho una autoridad mundial en derecho internacional ${ }^{89}$. Su doctrina en este campo constituía un desarrollo autónomo de la «Teoría pura» (si era un desarrollo coherente o no es otro tema) que ahora tomará la delantera momentáneamente (KELSEN, 1920a; MÉTALL, 1976: 86-87). Comienza así a publicar de manera intensiva en inglés sobre diversas cuestiones relacionadas con la estructura institucional del derecho internacional y el nuevo sistema de las Naciones Unidas ${ }^{90}$. No abandona por ello la teoría del derecho - de hecho escribe también en ese idioma un buen número de trabajos en los que trata de entablar diálogo crítico con la jurisprudence anglosajona ${ }^{91}$ y pone a punto en 1945 la presentación en lengua inglesa de la teoría pura: la General Theory of Law and State (KELSEN, 1945c) —, pero será el derecho internacional la plataforma desde la que KELSEN va a desarrollar principalmente su trabajo y contemplar el derecho - y el mundo- en los años siguientes. Y en esa plataforma hallaremos también buena parte de la respuesta a nuestros interrogantes.

Hay que suponer, por tanto, que KELSEN estaba al cabo de la calle sobre la situación internacional de España al término de la guerra. Para empezar, desde luego, debía de saber de la condena al régimen de FRANCO hecha por la Asamblea General de las Naciones Unidas en 1946, en una Resolución donde se recordaba que era «en origen, naturaleza, estructura y conducta general, un régimen de carácter fascista, establecido en gran parte gracias a la ayuda recibida de la Alemania nazi de Hitler y de la Italia fascista de Mussolini» ${ }^{92}$. Pero también tuvo que ser testigo de cómo este rechazo se suavizó de inmediato y en muy pocos años, por efecto del nuevo escenario político abierto por la guerra fría, acabó revirtiéndose.

La citada resolución dio lugar efectivamente a la retirada de embajadores de Madrid (con la excepción de Argentina, Portugal, Irlanda, Suiza y el Vaticano) y a que Francia cerrase la frontera pirenaica. Pero en eso y poco más se quedó en los hechos la reacción internacional contra el régimen de FRANCO. Un par de años después, hacia 1948, cuando en Salamanca se comienza a planificar el doctorado bonoris causa de FRANCO, el riesgo de intervención aliada en España prácticamente se había disipado ${ }^{93}$ y comienza a hacerse necesario desarticular la política aislacionista mantenida has-

89 Había escrito una crítica muy influyente del Pacto de la Sociedad de Naciones y diversos trabajos sobre la estructura del orden jurídico internacional (KELSEN, 1935b, 1938, 1939). Cfr. BERNSTORFF/DUNLAP, 2010: 191 y ss.

90 Entre 1941 y 1951 publica al menos 23 artículos en las principales revistas estadounidenses sobre los siguientes temas: responsabilidad internacional individual y colectiva, jurisdicción obligatoria, interpretación de la Carta, justicia internacional, diferencias entre el sistema ONU y la Sociedad de Naciones, el tratado de la OTAN, reconocimiento internacional, sanciones internacionales, el estatus jurídico de Alemania, el principio de igual soberanía de los Estados, la regla contraria al derecho ex post facto en relación con la persecución de los crímenes de guerra del Eje, el Consejo de seguridad, los juicios de Núremberg,... Muchos de estos trabajos son posteriormente compilados en libros (KELSEN, 1944a; 1950). En 1952 publica los Principles of International Law (KELSEN, 1952). Ya en 1942 habían aparecido sus conferencias Oliver Wendell Holmes de Harvard (KELSEN, 1942).

91 KELSEN, 1941a, 1941b. Este último texto presenta un claro entronque con la tesis del derecho como «ingeniería social» de POUND.

92 Resolución 39/1 de la Asamblea General de las Naciones Unidas sobre Relaciones de los Miembros de las Naciones Unidas con España, 12 de diciembre de 1946.

93 Se desbloquea la frontera con Francia en 1948. En 1950 la Resolución 386/5 de la Asamblea General sobre relaciones de los Estados Miembros y de los organismos especializados con España (4 de noviembre) revoca la recomendaciones previas de cuarentena. 
ta el momento por parte del régimen. FRANCO utilizó la condena internacional para envolver en la bandera del patriotismo su política de autarquía económica («Si ellos tienen UNO [United Nations Organization], nosotros tenemos dos»), y de paso disimular el estrepitoso fracaso de la misma, que se debió más a causas endógenas (el nefasto control de la política económica en manos de ministros mediocres e ineptos, fundamentalmente militares o ingenieros) que a la exclusión exterior de España del Plan Marshall ${ }^{94}$. Lo insostenible de la situación terminó forzando un giro de la política hacia la integración de España en la economía internacional. Fue esto lo que obligó al régimen, a fin de asegurar su perduración, a iniciar una estrategia aperturista estableciendo contactos diplomáticos y estratégicos con el Vaticano y Estados Unidos. En el caso del Vaticano, una alianza proporcionaba la sanción legitimadora al Nuevo Estado que pretendía institucionalizarse y al que la Ley de Sucesión de 1947 definía como un reino sin rey pero con un caudillo que utilizaba a la iglesia exactamente a la manera de un monarca medieval teocrático. La iglesia consideró a FRANCO un «enviado de Dios» que condujo la «Cruzada» a la victoria. A cambio en el Concordato la iglesia obtuvo el monopolio de la enseñanza y del control moral de la sociedad además del derecho exclusivo a hacer proselitismo en su condición de religión oficial del Estado. En 1953, tras la firma, Pío XII le concedió a FRANCO, «nuestro amado hijo», la más alta condecoración del Vaticano, la Suprema Orden de Cristo. Un año después, el Nuncio asistía a la investidura doctoral de FRANCO en Salamanca.

Pero desde el punto de vista político fueron mucho más decisivos para España los tratados estratégicos de defensa que se firmaron en septiembre de ese mismo año con Estados Unidos. El tablero internacional se había reordenado y la nueva política de bloques hizo que el régimen de FrANCO transmutase sustancialmente su significado político a ojos de Estados Unidos: de régimen fascista enemigo pasó a ser un aliado contra un tercer enemigo considerado mucho peor, la URSS. Ahora resultaba estar también en el interés objetivo de Estados Unidos modificar sus relaciones con el régimen de FRANCO.

\section{DEL ANTIFASCISMO AL ANTICOMUNISMO}

Es, en efecto, en este momento cuando se impone con la administración Truman la doctrina de la «contención» orientada a impedir políticamente a toda costa la expansión del comunismo a terceros países. Dentro de Estados Unidos éstos son también los duros años del macartismo (1947-54). En una carta de 1940, recién llegado allí, KELSEN escribía a E. K. WINTER (quien quería ganarle para la causa activista del comité austroamericano de exiliados que había fundado en Nueva York): «[...] quisiera estar fundamentalmente distanciado de toda política. Ante todo, porque no soy en realidad hombre político, y además porque creo que debido a mi ascendencia debo ser particularmente cauteloso». Pensaba dedicarse exclusivamente a la ciencia, por tanto. Sin

94 Así lo exigían la altísima inflación, la penuria social, la protesta obrera y la necesidad empresarial de energía y crédito para el desarrollo técnico e industrial. FRANCO, sin embargo, retrasó ese momento todo lo que pudo (en rigor sólo inició el cambio, y aun entonces a disgusto, al final de la década). Como bien resume PRESTON: «España pagó el precio económico de la supervivencia de Franco» (PRESTON, 1994: 756). 
embargo, no le fue posible en absoluto mantener esa neutralidad. Muy pronto apareció referenciado en documentos del FBI (1944) y se le catalogó entre los emigrantes austríacos dentro del grupo de los «liberales» (1945). ${ }^{95}$ Desde la puesta en marcha de la «doctrina Truman» en 1947 y la instauración del Loyalty Programm del senador MACCARTHY (por el que todos los empleados públicos debían probar su no pertenencia al partido comunista), hacia 1953 unas 20.000 personas habían sido investigadas. Entre ellas estaba KELSEN.

Es significativo que las investigaciones se dirigieran contra miembros o simpatizantes del Communist Party estadounidense (que en 1940 contaba con unos 100.000 militantes) pero no contra los antiguos miembros del Partido Nacionalsocialista que habían emigrado ilegalmente a Estados Unidos. El informe del FBI sobre KELSEN (de 190 páginas) reflejaba, entre otras cosas, que se había pronunciado críticamente en relación con el juramento de lealtad anticomunista introducido por la universidad californiana en 1950. Un grupo de 31 profesores se apartó de la mayoría del claustro negándose a realizar el loyalty oath y uno de ellos, Harold WINKLER, un joven Assistant Professor de ciencia política de 36 años, fue despedido mientras que otros dimitieron y todo el asunto generó una enorme polémica dentro y fuera de la universidad. KELSEN sí había hecho el juramento, pero conocía a WINKLER desde su época de Harvard donde éste había hecho su doctorado. Precisamente KELSEN se hallaba entonces como Visiting Lecturer (de septiembre a enero de 1950) en su antigua universidad, la cual había acogido de vuelta a WINKLER tras ser despedido de Berkeley. En una entrevista al diario estudiantil The Harvard Crimson decía que el juramento era «ciertamente innecesario» pero que no le molestaba particularmente ni creía que significara el fin de la libertad de cátedra en su país ${ }^{96}$ : que había supuesto un daño sobre todo para la universidad. Destacaba también que el problema central no era el juramento en sí, sino la decisión previa de excluir a los comunistas de la enseñanza y que en esta política aprobada por mayoría en la universidad radicaba el «problema moral» del asunto; pero no creía que fuera «un serio peligro» dado que «la medida se dirige sólo a los comunistas, quienes su vez no reconocen el principio de libertad académica de ninguna manera». Estas declaraciones despertaron una fuerte reacción y KELSEN se vio obligado a matizar de inmediato sus afirmaciones en una carta al editor, mostrando su apoyo y respeto a quienes rechazaron el juramento ${ }^{97}$.

95 La descripción era: «Professor Hans Kelsen 60, eminent jurist, wrote Constitution of Austrian Republic, University of California; at present consultant for FEA (Foreign Economic Administration)》.

96 Recuérdese que KELSEN y su mujer eran ciudadanos estadounidenses desde hacía cinco años.

${ }_{97}$ Uno de los profesores que habían dimitido rehusando firmar el juramento, Ludwig EDELSTEIN, especialista en cultura clásica griega, había escrito una carta a la revista en la que puntualizaba que «el problema moral de fondo en este asunto» no era la exclusión de los comunistas de la Facultad ni el mayor o menor peligro del juramento o si éste amenazaba la libertad de cátedra, sino «si estamos dispuestos o no todavía a tolerar las diferencias de opinión, si nos rebajamos o no ante medidas totalitarias, se llamen comunistas o fascistas». KELSEN relata en su Autobiografía que cuando en la Universidad de Viena se debatió si ésta debía participar en los consejos obreros que había instituido el partido socialdemócrata austríaco en 1927 y donde se establecía como condición la profesión de marxismo, se opuso a ello frontalmente por considerar que tal cosa «era incompatible con el principio de libertad de la ciencia». KELSEN declaraba abiertamente su simpatía por la socialdemocracia, «pero más fuerte que esa simpatía era y es mi necesidad de independencia político-partidista en mi oficio. Lo que yo no concedía al Estado, el derecho a limitar la libertad de investigación y expresión de opiniones, tampoco podía reconocerlo a un partido político» (KELSEN, 2008: 116-118). No parecía encontrar ahora, en 1950, sin embargo, simetría alguna entre la profesión de comunismo y la profesión de anticomunismo. 
Pero la principal (y sorprendente) consecuencia de todo ello fue que el FBI inició una investigación a fondo sobre el propio KELSEN bajo sospecha de ser comunista, en la que también participó la CIA, que se prolongó hasta 1955 y cuyas actas no serían definitivamente archivadas hasta ¡1963! La investigación, naturalmente, concluyó sin resultado alguno. Pues todo lo que pudo hallarse contra KELSEN es lo que hemos relatado y dos multas de tráfico. En el curso de los interrogatorios acerca de él, un informante cuyo nombre desconocemos (porque las actas son públicas pero contienen lagunas y fueron parcialmente censuradas, si bien lo más probable es que se tratara de un colega de la Universidad de California), declaró que KeLSEN no sólo no era comunista sino «a día de hoy uno de los más enérgicos y mejor informados oponentes del comunismo en el mundo», cuyo libro «titulado The Political Theory of Bolshevism: A Critical Analysis, publicado por la Universidad de California en 1948, es un ataque maestro contra la teoría del comunismo y contra la Unión Soviética». La investigación del FBI alcanzó así, en ulteriores entrevistas, al examen de la obra escrita del jurista austríaco para tratar de medir su proximidad con la socialdemocracia austríaca y la distancia de ésta con el comunismo ${ }^{98}$.

No parece casual, pues, dentro de tal paranoide ambiente institucional-político, que KeLSEN publicara en 1955 su libro The Communist Theory of Law (Kelsen, 1955a). Ahí pretendía mostrar las «contradicciones» del marxismo como teoría del derecho conectándolas con la política soviética. Harold J. BERMAN, profesor de Harvard y buen conocedor del tema, hizo una reseña del libro muy crítica con tal pretensión, mostrando con ironía cómo KELSEN confundía ilegítimamente la crítica a una teoría del derecho (la del materialismo histórico de MARX y ENGELS) con la crítica a una ortodoxia política, y que era él mismo quien se contradecía al presentar a esa teoría, por un lado, como sumisa apología de la política soviética (una «sierva del gobierno soviético») y, por otro, como «iusnaturalista» (esto es, crítica del derecho positivo) (BERMAN, 1955). Y ello además (añadiría yo) pretendiendo aducir que la teoría jurídica soviética era la consecuencia directa del postulado marxista acerca del carácter ideológico, comprometido y no neutral, de toda ciencia social (KELSEN, 1955a: 44 y ss., 193). Lo cierto es que tanto esta obra de KELSEN como el opúsculo de 1948 sobre la teoría política del bolchevismo constituían — también — una palmaria verificación de tal postulado. Ambos son trabajos «de combate», de alineación ideológica ${ }^{99}$, lo que se refleja ya desde

98 Así se refleja en el «screening» en el que se indagaba acerca de su valoración del socialismo del siguiente modo: «Kelsen was asked "Are you interested in the Socialistic program?". He answered: "I am very interested and as far as I am concerned I think it is absolutely necessary to adopt in our form of government some of the Socialist ideas". He was also asked the following questions, his answers being indicated after each question: "Q: You are in sympathy with the Socialist? A: Yes, I am. Q: With the Communistic? A: No, I am not. I published a book against them. Q: Would you describe yourself as a Communist or a Socialist? A: I would as a Liberal Socialist» (resaltado original). Extraigo casi todos los datos citados sobre la investigación del FBI de RATHKOLB (2009). Las cartas de Edelstein (20 de noviembre) y KELSEN (4 de diciembre) pueden leerse en la web de la revista thecrimson.com. La entrevista, en cambio, de 1 de noviembre, no está disponible ahí: agradezco de nuevo a los bibliotecarios de la Pusey Library de Harvard que me facilitaran una copia.

${ }_{99}$ Al comienzo de The Political Theory of Bolshevism afirma KELSEN: «Particular énfasis se hará sobre la demostración de que el eslogan de las dos democracias — formal-política una, sustantiva-económica otra - es falso. [...] La interpretación de la democracia implica así la decisión entre dos procesos fundamentalmente diferentes de los cuales quizá dependerá el futuro de la humanidad» (KELSEN, 1948: 2). La significación ideológica de estas palabras y de la maniquea dicotomía sobre las que se construye el panfleto (democracia/totalitarismo) resulta clara si se contemplan a la luz del discurso que TRUMAN dirige en 1947 al Congreso estadounidense defi- 
el título, y se limitan a repetir, ahora amplificadas y agudizadas convenientemente, las ideas expuestas por KELSEN en alemán en los años veinte y treinta sobre el marxismo y el socialismo (KELSEN, 1920b; 1923; 1924; 1929; 1931). Sin embargo, sus simpatías por el socialismo - y hasta por el materialismo histórico y el movimiento obrero- eran, con todo, bastante mayores en esas décadas que ahora ${ }^{100}$. LOSANO (1989: 99) ha hablado de un «peaje pagado al macartismo» por KELSEN. RuIZ MANERO (1986, 198, n. 27), por su parte, encuentra esta observación «francamente exagerada» y la matiza citando entre otras cosas el artículo de KELSEN «The Foundations of Democracy» como prueba de que éste defendía por escrito en esa época la compatibilidad entre socialismo y democracia ${ }^{101}$. Lo cierto es que ambos llevan razón.

\section{FINAL: ¿UN ERROR DE KELSEN? ¿UNA OCASIÓN PERDIDA?}

De manera que en el momento de recibir su invitación a Salamanca, entre 19531954, KELSEN veía cómo su reputación estaba siendo puesta a prueba (aún continuaba la investigación del FBI). Infructuosamente, por supuesto, pero su renombre como jurista y su nueva posición en Estados Unidos no podían peligrar por la sospecha de ser «comunista». En otro momento habría considerado un trance así como una consecuencia de la imparcialidad de su doctrina, que también había sido atacada desde

niendo el conflicto entre los dos bloques de la guerra fría como el existente entre «pueblos libres» y «regímenes totalitarios». El libro fue, por lo demás, recensionado muy elogiosamente por H. L. ROBERTS en el número 27 (1948-1949) de Foreign Affairs, revista muy vinculada como se sabe a la política exterior norteamericana, en cuyas páginas precisamente acababa de ser expuesta en el mismo año por G. F. KENNAN la «doctrina de la contención» que ese discurso llevó a la práctica. Según MéTALL, KELSEN participó en agosto de 1947 en un seminario de la Brookings Institution (uno de los think tanks más antiguos de Washington) dedicado «a los problemas de la política exterior norteamericana» (MÉTALL, 1976: 87). Una recensión igualmente muy laudatoria de The Communist Theory of Law apareció en Foreign Affairs en julio de 1955.

100 En el prefacio a la segunda edición de Sozialismus und Staat (1923) dice KELSEN: «mi pensamiento no se dirige contra el socialismo, sino que sólo contesto críticamente al marxismo y, dentro de éste, sólo a su teoría política. Lo que está en cuestión no es la idea socialista», sino solamente la posibilidad defendida por el marxismo de una realización del mismo al margen del Estado. Vid. también lo que dice en su autobiografía (KELSEN, 2008: 117-8). KELSEN en realidad aceptaba del marxismo la teoría de las ideologías y la teoría explotadora del Estado fruto de la lucha de clases (rechazaba la dialéctica «que se pierde en místicas tinieblas», pero reivindicaba el «procedimiento dialéctico-contradictorio del parlamento»). Lo que siempre rechazó rotundamente (y con razón) era la articulación práctica de un proyecto político basado exclusivamente en la dominación de una clase (el proletariado industrial) como «clase universal» y, sobre todo, la tesis concomitante de la extinción «anarquista» de las clases sociales y, por tanto, del Estado mismo. Esta tesis le parecía inconsistente con cualquier proyecto político-jurídico que tomase en serio el papel normativo y transformador del derecho, como la propia evolución doctrinal de los juristas soviéticos evidenció. Pero si frente a ello antes propugnaba la «vuelta a Lassalle», haciendo con ello una crítica «plenamente interna» del marxismo, ahora (en Estados Unidos y con la URSS enfrente) considerará al bolchevismo como la verdadera interpretación del marxismo, al tiempo que oculta los aspectos positivos del sistema «democrático» de los soviets señalados en Sozialismus und Staat (RuIZ MANERO, 1988: 38 y ss., 42, 52).

101 KeLSEN, 1955b. Un año antes (el 30 de abril de 1954, es decir, en las fechas en que tendría que hallarse en Salamanca para recoger su doctorado honoris causa) pronunciaba en la Law School de Chicago la conferencia «Democracy and Socialism» (Conference Series, 15/1955, 63-87). En su Autobiografía escribe: «Con el programa democrático del partido austríaco [el SDAP, Partido Social Demócrata de los Trabajadores], que sin duda se encontraba fundamentalmente en el campo del marxismo, pero en la práctica nada tenía que ver con la teoría estatal anarquista de MARX y ENGELS, estuve yo desde el comienzo en un total acuerdo. [...] De esta manera plena simpatizaba yo personalmente con un partido al mismo tiempo socialista y democrático y de esa empatía no hice nunca un secreto» (KELSEN, 2008: 117-118). 
el otro extremo del espectro ideológico por «burguesa». Sin embargo, ahora la nueva nueva condición de ciudadano estadounidense que ostentaba y el nuevo escenario de polarización internacional estaban muy lejos de tolerar cualquier clase de neutralidad y forzaban a tomar partido, cosa que KELSEN hizo. Su tendencia era afín a la socialdemocracia europea, pero lo que más importaba ahora era su nítido posicionamiento anticomunista. Esta es, como decíamos, una clave importante para entender su actitud hacia España.

La valoración de su nombramiento como doctor bonoris causa por Salamanca tuvo que estar mediatizada por la valoración de Estados Unidos sobre el régimen de FRANCO y sus perspectivas de continuidad. Y éstas acababan de mudar drásticamente. Ya desde 1948 el gobierno norteamericano había iniciado el establecimiento de contactos con las autoridades militares españolas para una futura cooperación. Dadas las dificultades políticas para entrar en la OTAN (Inglaterra y Francia se oponían), la única solución posible era un acuerdo bilateral en el que España pondría bases militares al servicio de los aliados. Las negociaciones comenzaron en 1951 y Estados Unidos estaba enormemente interesado en llegar a un acuerdo, pese a que TRUMAN no guardaba simpatía alguna por FRANCO sino más bien todo lo contrario (debido entre otras cosas a su intolerancia religiosa). Pero FRANCO estaba mucho más interesado aún en ello, sabedor de que se jugaba la pervivencia del régimen. Emprendió toda una campaña propagandística en Estados Unidos intentando sacar partido de su cruzada anticomunista ${ }^{102}$. Finalmente, sin embargo, toda esta hinchada grandilocuencia quedó ridiculizada en los hechos por la mala gestión de la negociación que hizo el gobierno español, obligado a aceptar en el último momento prácticamente en bloque las condiciones estadounidenses. Estados Unidos logró de plano sus objetivos estratégicos con los acuerdos de Madrid. Pero para FRANCO éstos fueron absolutamente decisivos, ya que aseguraron efectivamente la continuidad del régimen reduciendo de forma drástica la presión externa e interna sobre él. En el orden exterior FRANCO pudo legitimarse y enseguida se escenificó el cambio con la entrada de España en la ONU dos años después, en 1955. Dentro, pudo continuar con su política de represión («ley y orden») acusando a los conspiradores comunistas y masones de todas las desgracias del país. De esta manera se consolidó la singularidad del régimen franquista en la vieja Europa.

KELSEN, buen conocedor de la situación europea por diferentes conceptos, no podía ignorar todo esto. Por un lado, políticamente hablando, decir que sí a Salamanca significaba desde luego aceptar la invitación de un país que había optado resueltamente por una de las dos únicas alternativas existentes: la del capitalismo (al menos por negación furibunda de la otra), y un país que (para Estados Unidos) jugaba un importante papel en el nuevo mapa político de Europa que (desde Estados Unidos) se estaba configurando. Era también por ello una ocasión para exhibir su profesión

102 FRANCO apareció en septiembre de 1952 en una entrevista en The Washington Post hablando del estado de las negociaciones y ofreciéndose como parapeto frente al bloque soviético y en otra posterior (ya con EISENHOWER como presidente en 1953) elogiando - vestido de uniforme tratando de igualarse con el general norteamericano- el papel de Estados Unidos en la Guerra de Corea. En la prensa española se hacían fotomontajes de FRANCO y EISENHOWER presentando a éste como un recién llegado al anticomunismo y el acuerdo como un triunfo del Caudillo que asombraba al mundo. Cfr. ABC, 27, 29 y 30 de septiembre de 1953. 
anticomunista. Pero, por otro lado, desde un punto de vista personal, seguramente para KELSEN todo esto no era todavía una razón concluyente (a la altura ya de 1954). Sabía muy bien que se trataba de un régimen fascistizado. Es probable que no ignorase que FRANCO recibiría también el doctorado en lo que iba a ser una ceremonia de pura glorificación política, ni que el Rector de Salamanca había sido el mismísimo intérprete de la reunión de Hendaya entre Hitler y FrAnCO de 1940. Tampoco podía desconocer la deriva franquista de su antiguo y más importante discípulo español LEGAZ ${ }^{103}$. Todo lo cual era sin duda de difícil digestión. Pero académicamente aquel era, de todas maneras, un gran reconocimiento para su carrera: rechazarlo le parecía también demasiado. No habría por qué identificar absolutamente a Salamanca con FRANCO: al fin y al cabo se trataba de una de las universidades europeas más antiguas y era Europa, además, de donde únicamente podía esperar ya homenajes de ese tipo. Por otra parte, la propia Universidad de California había enviado un delegado a los actos de octubre de 1953 y hasta en el doctorado de FRANCO estuvo presente un agregado de la embajada estadounidense en España ${ }^{104}$. El balance de todos estos elementos dio lugar, como sabemos, a un curso de acción más próximo a la negativa que a la aceptación tácita, y se materializó en una actitud de prudente distancia. KELSEN no rechazó la invitación pero tampoco lo aceptó de forma expresa, sino que se mantuvo en silencio hasta que, transcurrido un plazo que hacía ya imposible la asistencia, aceptó en el último momento su proclamación como doctor honoris causa en ausencia al ser apremiado en tal sentido desde Salamanca.

Su inasistencia era el minimum exigible, dadas las circunstancias. Ahora bien: ¿era rechazar el nombramiento y decir que no a Salamanca (lo que sería también un no al régimen franquista) un maximum heroico, «supererogatorio»? Ya he manifestado mi opinión negativa al respecto. No creo que tal conducta fuera inexigible: dadas sus circunstancias y sobre todo su cargado y significado equipaje biográfico, KELSEN pudo y debió rehusar la participación (aunque fuera en ausencia) en el mismo acto en que se

103 En 1972 declaraba LEGAZ, ambiguamente: «no soy un seguidor — no al menos un seguidor de estricta observancia - de la teoría pura del Derecho» pero «mi producción filosófico-jurídica está condicionada por los planteamientos de la teoría pura del derecho» (LEGAZ, 1972: 77). En este texto —una conferencia dictada en la Facultad de Derecho de Coimbra con motivo del noventa aniversario de KELSEN- se refiere también al artículo que había escrito treinta años atrás defendiendo «el valor actual» de la teoría de KELSEN (y que ya hemos citado: LEGAZ, 1942), afirmando que ya en él subrayaba que la teoría pura «conserva cierta validez» pero «sin comprometerme en una defensa integral de la misma», sino sólo saliendo al paso «de los desconocimientos o de los improperios que le dirigían los juristas de esos años», y dejando claro que «constituía una superlativa frivolidad criticarlo en nombre de lo que, en otro momento estaba de moda» (LEGAZ, 1972: 78). Es obvia la calculada equivocidad y reinterpretación acomodaticia del pretérito en estas palabras de LEGAZ en 1972, puesto que lo que hubo por su parte en los años cuarenta fue un inequívoco intento de utilización ideológica del kelsenismo al servicio del Nuevo Estado, intento que rectificó al principio de los años cincuenta cuando el totalitarismo era un incómodo lastre ideológico que se hacía necesario abandonar. Entonces LEGAZ trata de recuperar de algún modo sus tesis sobre el Estado de Derecho anteriores a la guerra, de inspiración kelseniana, pero desvinculando ese concepto de la tradición liberal y de la «democracia de masas» para justificar la legitimidad del régimen franquista y la ruptura con la legalidad republicana (LEGAZ, 1951; cfr. al respecto GARCÍA MANRIQUE, 1996: 229 y ss.). En la conferencia sobre KELSEN de 1972, LEGAZ se distancia ya por completo de la idea de que «también el Estado nacional-socialista era un Estado de Derecho» (LEGAZ, 1972: 89). No sabemos si LEGAZ puede ser llamado un «discípulo» de KELSEN, por cuanto la relación de discipulado parece ser «bidireccional» y requerir reconocimiento recíproco. Sí es cierto, en todo caso, que KELSEN participó en el libro homenaje a LEGAZ (KELSEN, 1960).

$$
104 \text { VII Centenario. Programas de actos. Invitaciones. Protocolo. Alojamiento, AC 7566/2. }
$$


proclamaba a FRANCO doctor honoris causa en Derecho, evitando así prestarle la convalidación que su nombre y su prestigio comportaban.

No se trata aquí, naturalmente, de algo así como «juzgar» el comportamiento de KELSEN en abstracto, gratuitamente. Se trata ante todo de entenderlo desde sus concretos actos previos y también desde sus propias doctrinas: de entenderlo, por tanto, críticamente. Es evidente que no cabe «condenar» su conducta en términos simplistas, como si ésta respondiera, por ejemplo, a conformismo, a falta de resolución o debilidad de carácter. Si no rechazó la mención salmantina ello no fue desde luego por falta de valor. KELSEN había demostrado a lo largo de su vida en circunstancias bastante más inciertas y dramáticas tener un enorme coraje. Numerosos episodios podrían narrarse aquí en corroboración de tal rasgo de su carácter. Desde su valiente posición durante el conflicto de las dispensas que («bajo la presión de la Iglesia Católica») originó la disolución del Tribunal Constitucional austríaco y la marcha de KELSEN de Viena en 1930 [KELSEN, 2008: 135 y ss., 145], hasta su enfrentamiento con los que le atacaban por su origen judío en Viena en 1918 o con los nacionalsocialistas que le amenazaron de muerte en la Universidad Alemana de Praga tras su huida de Colonia (KELSEN, 2008: 160 y ss.; FEICHTINGER, 2009: 327), sin olvidar su viaje de vuelta a Europa desde Estados Unidos nada más estallar la guerra ${ }^{105}$. En realidad, todo su periplo vital había estado plagado de forzosas exhibiciones de estoicismo ante la cadena de adversidades que le tocó encarar y que le obligaron a recomenzar desde cero no en una sino en varias ocasiones: una verdadera «odisea», como dice JESTAEDT, en la que «Kelsen cambió cinco veces su sitio de actividad universitaria y ninguna de estas veces libre y espontáneamente» ${ }^{106}$. Pero de todos los recomienzos sin duda el más duro fue el de su última etapa norteamericana y su traslado a California, como ya hemos visto, donde llegó a encontrarse en una situación «extremadamente precaria», que su autobiografía dejaba sin embargo velada (NiTSCH, 2009: LXIV y ss.) ${ }^{107}$. Tuvo que ser muy frustrante, un desengaño casi vejatorio, el no encontrar acogida en la academia jurídica estadounidense para él, que venía de ser considerado como una leyenda en Europa: el gran jurista que apenas a la edad de cuarenta años, tras haber recibido el encargo de recomponer la unidad jurídica de un imperio en la forma de Estado

105 En 1939 KELSEN había viajado a Estados Unidos para acudir a una de las últimas conferencias del neopositivista Círculo de Viena (el Fifth International Congress for the Unity of Science celebrado en septiembre en Cambridge), aprovechando este viaje también para establecer su ya citada red de contactos con profesores y universidades americanas. Allí le sorprendió el estallido de la guerra, a partir del cual comenzó a hacer planes para el traslado definitivo de su familia. Sin embargo, a diferencia de muchos de sus colegas de emigración a Estados Unidos, KELSEN decidió aún regresar a Europa una vez más antes de su viaje definitivo al año siguiente. Él mismo confiesa en una carta a POUND que sabía estar corriendo «un gran riesgo» (cfr. NiTSCH, 2009: XXV y ss.).

106 JESTAEDT, 2008: 41, 44. El editor de la autobiografía kelseniana resalta cómo en ésta domina en general un tono «elegíaco», en el que lo que se destaca es «lo desagradable o inacabado, lo doloroso o malogrado»: «La vida de Kelsen puede ser también considerada como la historia de un ser indeseado». MÉTALL nos presenta igualmente a un hombre de perfil estoico pero pesimista.

107 Valga esta otra anécdota para ilustrar la soledad en que vivía KELSEN en Estados Unidos: en la primavera de 1945, cuando llevaba en Berkeley apenas dos años (y acababa de conseguir, junto con su mujer, la nacionalidad norteamericana), se comenzaron a reunir en San Francisco — a pocos kilómetros de allí- numerosos diplomáticos europeos para deliberar sobre la constitución de la ONU y muchos de ellos preguntaban por KELSEN interesándose por saber dónde vivía exactamente conocedores de que era por allí. Sólo entonces el Decano de la Facultad fue consciente de su importancia y le llamó para preguntarle si era él «el famoso Kelsen de Europa» del que todos hablaban, a lo que él respondió con un lacónico «sí». La historia la cuenta Th. OLECHOWSKI, 2011: 17, a raíz de una entrevista con Richard M. BuXBAUM, profesor de derecho en Berkeley. 
federal, había afrontado con éxito la tarea de diseñar una nueva constitución para la República de Austria inventando el sistema del control concentrado de constitucionalidad ${ }^{108}$ y ahora se encontraba casi a la edad de jubilarse con que su autoridad era escamoteada. Lo cierto es que KELSEN nunca encajó (y sigue sin hacerlo) en la cultura jurídica estadounidense, donde fue considerado al principio como un cuerpo extraño y después simplemente tolerado y respetado como una especie de supervivencia del formalismo jurídico y del neokantismo decimonónicos que allí se entendían superados ampliamente hacía mucho por los planteamientos realistas y pragmatistas (BERGMANN/ZeRBY, 1945; Telman, 2010). De hecho, como ya se apuntó, KELSEN no logró encontrar puesto fijo en ninguna Facultad de Derecho, sino solamente en Ciencia Política, donde a lo más que podía aspirar era a gozar de un ambiente tranquilo y de tiempo para trabajar, pero ya no a formar escuela ${ }^{109}$. Y, sin embargo, su respuesta fue una vez más la de sobreponerse a un entorno adverso a base de trabajo. Al rechazo académico replicó, como ya vimos, con la publicación masiva y sistemática en inglés con el objetivo de abrirse paso en el campo del derecho internacional, por entonces en trance de reorganización, y dar a conocer a los círculos académicos norteamericanos su teoría del derecho. A la marginación que sufrió por parte del gremio internacionalista y la exclusión de que fue objeto en el proceso de redacción de la Carta de las Naciones Unidas, reaccionó publicando un libro de casi mil páginas de comentarios críticos sobre la misma ${ }^{110}$. Académicamente hablando, KELSEN siempre hizo gala de una gran bravura: cualquiera que eche un vistazo a su ingente obra (más de 17.000 páginas publicadas) reconocerá a un polemista que no se achicaba ante nadie y se pasó su vida discutiendo con todo aquel adversario intelectual que se pusiera a tiro. Fueron más bien sus colegas estadounidenses quienes no quisieron discutir con él (TELMAN, 2011: 514 y ss.; GarCÍA-SALMONES, 2013: 170; PAUlson, 1988: 181; KENNEdy, 1995). Además de las ya apuntadas razones culturales (la peculiaridad del common law, el realismo jurídico dominante) ${ }^{111}$ y políticas (el nuevo papel estratégico de Estados Unidos como potencia imperial o «gendarme de Occidente» y la manera de entender el

108 Métall, 1976: 25 y ss.; Olechowski, 2009. Como señala Paulson, 2000: 389, Kelsen consideraba al Tribunal Constitucional su «hijo más querido» (cfr. MÉTALL, 1976: 44).

109 Al final de su Autobiografía KELSEN reconoce esta imposibilidad con palabras no exentas de desazón: «Mi actividad docente es plenamente satisfactoria. Sin duda hubiera sido mucho más adecuada para una facultad jurídica mi Teoría pura del Derecho. Pero las escuelas de derecho norteamericanas no tienen un especial interés en una teoría científica del derecho. Ellas son training schools —escuelas para el oficio jurídico- y su función es la preparación para el oficio práctico de un abogado» (KELSEN, 2008: 171-172). Como escribe LOSANO en su reseña del estudio de NITSCH, «el desinterés estadounidense por el aspecto teórico del derecho fue el gran despecho de KELSEN hasta el fin de su vida» (LOSANO, 2011: 256). La cátedra de KELSEN llevaba por nombre International Law, Jurisprudence, and Origin of Legal institutions.

110 El ya citado PASVOLSKY, jefe de la delegación norteamericana, había considerado las propuestas de KELSEN al respecto como «legalistic technicalities» (MÉTALL, 1976: 85). El normativismo formalista kelseniano fue considerado un obstáculo para el proyecto de orden político internacional que Estados Unidos quería implementar mediante la Carta.

111 Cfr. Telman (2010). Como señala este autor, no sólo los realistas rechazaban por principio un formalismo jurídico como el de la Teoría pura kelseniana (Karl LLEWELLYN llegó a considerarla «utterly sterile»). También un autor como Fuller coqueteaba con la reductio ad bitlerum del formalismo jurídico alemán al afirmar (precisamente en 1954) que éste había sido «notoriously deferential to authority» (FULLER, 1954: 466). Pero esta no podía ser la única razón explicativa, pues dentro de la misma cultura del common law la influencia de KELSEN dejó una importante huella en autores como HART o RAZ. La ausencia de eco de la teoría kelseniana en Estados Unidos es un tema recurrente: vid., p. ej., la discusión generada en el Brian Leiter's Legal Philosophy Blog bajo la entrada «Why don't American philosophers of law talk about Kelsen?». 
derecho internacional que significaba) ${ }^{112}$, hubo tras ello también factores sociológicos (derivados de la propia idiosincrasia profesional de la recién constituida clase académico-jurídica norteamericana [cfr. TELMAN, 2008: 12 y ss.]).

Por otra parte, la biografía de KELSEN pone de manifiesto también que era, sin la menor duda, una persona pragmática y dispuesta a pasar página, algo bien explicable en quien ha resistido duros embates vitales. Este rasgo a veces ha descolocado no poco a sus biógrafos. Así, por ejemplo, JESTAEDT (2008: 47) declara «no comprender en absoluto» que en su Autobiografía la toma del poder por HITLER «no le mereciera más de cuatro secas palabras». Otras veces, en cambio, ha sido ponderado como actitud generosa por su parte. Hay varios episodios clave de su vida que muestran cómo KELSEN pasó por encima de graves desaires y errores de personas próximas a él que sufrió hondamente en carne propia $\left(v . g\right.$. los de SANDER o COSSIO) ${ }^{113}$, cuando no directas y cobardes traiciones ( $v$. g. la de C. SCHмITT $)^{114}$. Tal actitud, aparte de señal de bonhomía, era quizá también el necesario correlato de ese pesimismo cuasihobbesiano antes apuntado, el cual venía a sumarse a su vez a una posición abiertamente escéptica ante cualquier género de fanatismo o fundamentalismo, ya fuera nacionalista o religioso. Sabemos que KELSEN cambió varias veces de nacionalidad y de confesión religiosa por conveniencias prácticas del momento ${ }^{115}$. Un escepticismo que, como se sabe, acabó

112 Sin embargo, en lo que respecta al derecho internacional al menos, tal vez el tiempo acabó dándole la razón al neokantiano KELSEN. El ideal del derecho como mecanismo para articular una «paz perpetua» fue desarrollado por KELSEN, a contracorriente, poniendo el acento no tanto en la legislación o codificación del ordenamiento internacional cuanto en la necesidad de instituir un tribunal internacional de jurisdicción obligatoria y universal capaz de operar la centralización de tal ordenamiento. Es de subrayar que KELSEN concedía a este tribunal las facultades de desarrollo jurídico en términos de principios que su teoría del derecho negaba, sin embargo, a los tribunales constitucionales nacionales (los cuales seguían siendo concebidos más como poder legislativo que judicial). Cfr. TELMAN, 2011: 527, n. 102 y 528, n. 112. Los tribunales internacionales temporales para Ruanda y la antigua Yugoslavia y la tentativa institucionalización de un Tribunal Penal Internacional caminan, pues, en la senda kelseniana.

113 F. SANDER, discípulo de KELSEN en Viena, le acusó infundadamente de plagio en 1921. En su biografía KELSEN se extiende considerablemente sobre el caso y narra cómo, pese a todo, KELSEN recomendó más tarde a SANDER para una cátedra en Praga y terminó reconciliándose con él allí, incluso sabiendo de su colaboración con los nacionalsocialistas (KELSEN, 2008: 123-129; MéTALL, 1976: 46 y ss.). En cuanto al desencuentro con C. Cossio, tuvo lugar a raíz de la visita que KELSEN hizo a Buenos Aires invitado por aquél. El contexto de esta visita argentina, por cierto, guarda bastante similitud con la visita española. También aquí un gobierno totalitario, el peronista, en pleno clima internacional de guerra fría, buscó aprovechar ideológica y académicamente la presencia de KELSEN para legitimar la recién aprobada Constitución de 1949. Algunos juristas antiperonistas incluso advierten de ello a KELSEN por carta y éste finalmente, para contrarrestar el apoyo al oficialismo a que pudo dar lugar, accede a dictar una conferencia en un diario opositor (SARLO, 2010: 407, 409, 412; MÉTALL, 1976: 89). Aparte del choque de personalidades, de las tensiones de la discusión verbal ( $c f r$. ATIENZA, 1984: 45) y de la disputa propiamente intelectual de fondo (KELSEN rechazaba la interpretación egológica de la Teoría pura), la ruptura arrancó de la decisión unilateral del filósofo argentino de publicar en 1952 un volumen conjunto conteniendo las conferencias de KELSEN unidas a su propio «Balance provisional». Pese a todo KELSEN no dejó de dar beligerancia intelectual a la tesis de Cossio en la segunda edición de la Teoría pura de 1960.

114 SCHMiTT (con quien ya se había enfrentado en 1931 en la famosa polémica sobre el «guardián» de la Constitución) fue el único colega que no firmó la carta de apoyo contra su depuración de la Facultad de Derecho de Colonia, donde KELSEN era decano. Detalles al respecto en SOSA WAGNER, 2004: 179 y 238 y MÜLLER 2011: 65ss.. MéTALL apunta (quizá recogiendo la impresión de KELSEN) que a fin de cuentas SCHMITT le hizo un favor involuntario, «porque si se hubiera quedado, habría sufrido algo peor que un simple cese» (MÉTALL, 1976: 61).

115 Cambió de nacionalidad austríaca a alemana en 1930 cuando desde Viena se trasladó a Colonia como profesor, posteriormente adquirió la checoslovaca al ir a la Universidad de Praga y por último renunció a ella para asumir la estadounidense en 1945 (MÉTALL insiste varias veces en que KELSEN es «indiferente a la nacio- 
extendiéndose a todo el espectro axiológico para transformarse finalmente en relativismo moral (único y exiguo apoyo filosófico que KELSEN supo hallar para la democracia como forma de organización política basada en el pluralismo).

La adopción de un pragmatismo escéptico semejante debió de estar, pues, a la base de la posición de KELSEN ante el doctorado bonoris causa de Salamanca en 1954, cuando ni acepta el nombramiento ni acude al acto, pero tampoco lo rechaza y consiente en ser investido en ausencia. Y el mismo razonamiento pragmático pudo operar, ahora intensificado, en 1956 cuando KELSEN visita Granada. Intensificado, porque ahora el asunto podía verse retrospectivamente. Que se hallara personalmente en España marcaba, como es natural, una diferencia. Venía de Ginebra, donde ya sabemos que se sentía «en casa»: él era un europeo, forjado en el ambiente del racionalismo y el universalismo cosmopolita de los años de Viena (GARCÍA-SALMONES, 2013: 158 y ss.), el mismo ambiente que se respiraba en el seno del Institut de Droit International. Encapsulado en la culta y elitista «burbuja» de esa reunión, aparentemente distanciada de todo tacticismo geopolítico, se trataba en efecto nada más que de doctrina internacional. Para entonces incluso los internacionalistas estadounidenses habían abandonado ya su hostilidad de años atrás: su propia presencia en el Institut como miembro honorario era posiblemente una consecuencia de ello ${ }^{116}$. Y dentro de esa cápsula (esa «gran familia», según las palabras de YANGUAS) todo contribuía a escenificar diplomáticamente el aperturismo y la normalización de relaciones de España en el concierto internacional, recién consumado su ingreso en la ONU apenas un año atrás: resultado de ello era también que la propia reunión del Institut aconteciese en Granada («ningún Estado puede bastarse a sí mismo»). De modo que no resulta extraño que KELSEN no encontrara ya los mismos reparos y pudiera interesarse por recobrar el título de doctor bonoris causa de Salamanca, acreditativo del grand honneur avec lequel l'une des plus anciennes et plus celèbres Universitès du monde m'a distingué, tal como escribe en su carta, cerrando con ello un capítulo pendiente. Ahora sí podía verse ya como un asunto de «ciencia» y no de «política».

Y, sin embargo, parece indudable que KELSEN se estaba engañando con ello. Traicionaba, cuando menos, el compromiso que su propia trayectoria biográfica había demostrado con ciertos valores ilustrados. Desmentía el juicio exigido por «su» moral relativa y particular, esa que famosamente explicaba al final de su última lección en Berkeley ${ }^{117}$. Pues evidentemente en aquella España no había ni libertad ni democracia ni tolerancia algunas, y la única paz existente era la impuesta a base de represión po-

nalidad»). De origen judío, KELSEN se convirtió al catolicismo en 1905 y al protestantismo en 1912, en ambos casos por razones ajenas a cualquier convicción religiosa (OLECHOWSKI, 2011: 8). En relación con su posición atea pueden verse las críticas que dirige a la «teología política» en su libro de 1964 publicado póstumamente (KELSEN, 2012).

116 No es banal seguramente recordar que la Fundación Carnegie financiaba el Institut de Droit International y G. A. FINCH, el otro jurista estadounidense presente en Granada (cuya crónica hemos citado), era el jefe de la división internacional de esa fundación además de director del American Journal of International Law.

117 «And, indeed, I do not know, and I cannot say what justice is, the absolute justice for which mankind is longing. I must acquiesce in a relative justice ans I can only say what justice is to me. Since science is my profession, and hence the most important thing in my life, justice, to me, is that social order under whose protection the search for truth can prosper. "My" justice, then, is the justice of freedom, the justice of peace, the justice of democracy — the justice of tolerance» (KELSEN, 1957: 24). El audio original de la lección está disponible en bttp:// gradlectures.berkeley.edu/lecture/what-is-justice/ (fecha consulta 1 de febrero de 2015). 
lítica y manipulación social e ideológica (por no decir la paz de los cementerios y las fosas comunes [EsCUDERO/PÉREZ, 2013]). No era sino ponerse una venda -o pura falsa conciencia - tratar de aplicar aquí cualquier versión de la máxima metódica de la «pureza» o neutralidad política, pretendiendo que sería posible separar o escindir perfectamente (pues de eso va la metáfora de la Reinbeit: de no mezclar) lo político-moral de lo científico para así poder considerar ad hoc aquel acto como «puramente académico». Éste era, en realidad, un mixtum en donde la ciencia y la política, la universidad y el régimen franquista, se fundían de forma inextricable («El Caudillo para la Universidad y la Universidad para el Caudillo») y, lo que es peor, seguirían haciéndolo por mucho tiempo. Pues, ciertamente, nada había cambiado sustancialmente en España a la altura de 1956. Solamente la apariencia diplomática de las relaciones internacionales podía hacer pensar ilusoriamente otra cosa. El régimen de FRANCO continuó al menos hasta bien entrada la década siguiente sin experimentar transformación esencial alguna y los cambios producidos fueron contra la voluntad del dictador ${ }^{118}$.

Con su gesto de reivindicar el título de doctor bonoris causa, abandonando así su anterior distanciamiento, KELSEN no consiguió otra cosa que provocar de forma activa aquello que en 1954 quiso evitar pasivamente: que su nombre contribuyera de algún modo a legitimar - y fuese utilizado por - un régimen totalitario como el de FRANCO. La situación del momento histórico nos proporciona una analogía con otro relevante personaje que puede resultar, creo, sumamente ilustrativa para respaldar este juicio. En junio de 1953, el rector TOVAR escribe a ORTEGA Y GASSET (que había regresado a España en 1945 y acababa de cumplir setenta años tras un largo periodo de silencio, distanciado del régimen y vilipendiado por el fanatismo integrista católico) para proponerle que dictase la lección de clausura del curso académico 1952-1953 en la Universidad de Salamanca. La respuesta de ORTEGA también se basaba en invocar la neutralidad intelectual, sólo que de un modo irónico y para expresar el más rotundo rechazo: «En las circunstancias actuales —dice el filósofo- no me es posible una actuación de ese género y, en rigor, de ninguno como no sea publicar libros» ${ }^{119}$. ORTEGA cortaba así en seco cualquier posibilidad de acercamiento a lo que interpretaba como maniobra de instrumentalización. ¿No tenía KELSEN, mutatis mutandis, iguales razones y mejor posición para, al menos, hacer lo mismo?

Puede que KELSEN no estuviera al tanto de la situación personal de ORTEGA. Puede que ignorase también algunos otros lacerantes hechos de la España oficial de la época: como el homenaje que todavía en 1951 se celebró en el Ateneo de Madrid, presidido por Pedro ROCAMORA y acompañado del presidente del Tribunal Supremo José CASTÁN, al Mariscal PETAIN («el héroe de Verdún») y al fascismo francés, o la

118 El giro político-económico del franquismo sólo comenzó a producirse lentamente a partir del nuevo gobierno «tecnócrata» de 1957 encabezado por LóPEz-RoDó y el Plan de Estabilización de 1959. Hasta entonces se mantuvo la política de autarquía que puso al país al borde de la quiebra económica y que FRANCO abandonó con incomprensión. La Ley de Régimen Jurídico de la Administración del Estado de 1957 sentó las bases para una reorganización institucional del régimen en términos relativamente distanciados del puro poder personal del caudillo (se crearon la presidencia del gobierno, el procedimiento administrativo, etc.). Los efectos de estas reformas, sin embargo, no fueron perceptibles sino hasta varios años después.

119 Apud Morán, 1998: 470. Sabemos también por este libro, sin embargo, que la distancia de Ortega no le impidió seguir cobrando su sueldo de catedrático hasta su jubilación en 1953 pese a no regresar a la universidad después de 1936. 
conferencia del rector TOVAR reivindicando el falangismo en $1953^{120}$. Puede que desconociera el asesinato en febrero de 1953 en la Dirección General de Seguridad de Madrid de Tomás CENTENO, líder socialista de la UGT, o las protestas estudiantiles que determinaron la destitución en 1956 (apenas meses antes de su llegada a Granada) del ministro RuIZ-GiméNEZ que le hizo doctor honoris causa... o las huelgas obreras en Asturias y el País Vasco que se reprimieron con fuerza durante su misma estancia en Granada ${ }^{121}$. Pero lo que no podía desconocer es que el efecto simbólico deslegitimador de un hipotético rechazo expreso o condena suya — dada la auctoritas de que gozaba como jurista- habría tenido tal vez un alcance mucho mayor, por más que no cambiara demasiado las cosas, que el que tuvo su carta reclamando el diploma salmantino. No se trata (supongo que ni falta hace decirlo) de que KELSEN no mereciera poseer un honor como ése: probablemente nadie acumulaba mayor mérito que él en aquella ceremonia de Salamanca. Más bien era el doctorado de Salamanca el que no era merecedor de KELSEN. Pero tampoco KELSEN lo necesitaba, aunque él creyera que sí. Lo triste del asunto es que, en rigor, ni siquiera el régimen necesitó instrumentalizar a KELSEN, ni política ni académicamente. En lo ideológico-político, la continuidad del franquismo nunca precisó realmente recurrir a una legitimidad jurídica de tipo kelseniano, aunque no faltaran voluntarios ${ }^{122}$. $\mathrm{Y}$ en lo académico, por supuesto, continuó siendo perfectamente preterido: hubo que esperar al menos una generación para que KELSEN comenzara a ser estudiado de nuevo en España y de verdad $^{123}$. A cambio, KELSEN corría el sólo riesgo de perder una distinción académica que, por más que él tuviera — como sin duda la tenía- en alta valoración, carecía objetivamente del significado honorífico pretendido y terminó cubierta al cabo de los años por el desprestigio (en el caso de FRANCO, a quien le fue revocada) y por el silencio (en su propio caso).

Tal vez en esa aceptación por KELSEN del status quo puede reconocerse una clara manifestación - y una concreta consecuencia práctica- de la centralidad que en su normativismo tiene el llamado «principio de efectividad», es decir, la cruda facticidad del poder político (algo que sin duda lo revela también como pragmatismo). Fue el becho de la perduración eficaz de un régimen de origen totalitario y fascista como el

120 La conferencia, impartida en la sede central del Movimiento Nacional, ante la Guardia de Franco y retransmitida por radio a todo el país, llevaba por hábil título, obra de experto filólogo, Lo que a la Falange debe el Estado (Madrid, Delegación Nacional del Frente de Juventudes, 1953). En ella Tovar reconoce como una «catástrofe» la derrota del Eje y dice cosas como éstas: que el vencedor de la guerra mundial «no ha sido vencedor nuestro», que «vivimos en una época de restauración democrática, de vuelta al pasado», y que «seguimos orgullosos de que para ir a los Estados Unidos se exija el juramento de no ser falangista».

121 Los paros se debieron a la brutal subida de los precios y, extendidas por todo el norte de España, forzaron una reunión de emergencia del gobierno, de diez horas, el 29 de abril en el Alcázar de Sevilla, donde FRANCO visitaba la Feria. El 1. ${ }^{\circ}$ de mayo FrANCO imputaba a las logias masónicas y al comunismo internacional la organización de las revueltas dirigiéndose a 25.000 falangistas reunidos en esa ciudad. A continuación recordaba al país que España era constitucionalmente «una Monarquía sin realeza» (apud PRESTON, 1994: 817).

122 Ya hemos apuntado las contradicciones que entrañaban intentos como los de LEGAZ y otros de utilizar el normativismo formal (junto con otros ingredientes totalitarios y iusnaturalistas) para presentar el régimen franquista como un «Estado de Derecho». Contra esto reaccionó el temprano e influyente libro de Elías DíAz, Estado de Derecho y sociedad democrática, cuya primera edición es de 1966 (Madrid, Ed. Cuadernos para el Diálogo). Esa mixtión íntima de formalismo positivista y de iusnaturalismo dogmático explica probablemente muchas cosas de nuestra cultura jurídica.

123 Es significativo que el primer estudio serio, el de A. CALSAMIGLiA, Kelsen y la crisis de la ciencia jurídica (Barcelona, Ariel), sea precisamente del año 1978. 
de FRANCO después de la guerra, un hecho fabricado también desde Estados Unidos como hemos insistido, lo que aseguró la validez presupuesta de su Grundnorm. Pero tal concesión a los hechos del «ser» no dejaba de contrastar con la tesis que el propio KELSEN había mantenido en relación con la Alemania de posguerra. Aquí la continuidad jurídica exigía en su opinión la ruptura con el ordenamiento nazi, ilegalmente edificado ${ }^{124}$. La España franquista, en cambio, había pasado a legitimarse convertida en la misma entidad jurídica que la España republicana. Es difícil no acordarse de aquella celebrada metáfora que KELSEN mismo acuñó tempranamente (1927: 55), según la cual, después de alzar el velo, la mirada directa a los ojos de la Gorgona del poder produce irresistiblemente un efecto paralizante. Muy lejos queda la brillante sentencia con que nuestro protagonista cerraba su primer libro publicado en Estados Unidos: «La idea del derecho, pese a todo, parece todavía ser más fuerte que cualquier otra ideología del poder» (KELSEN, 1944a: 170).

O quizá el factor decisivo haya de ser buscado no en las teorías sino más bien en la pequeña escala de las relaciones humanas, no menos pragmáticas. Me refiero en concreto a una singular coincidencia que se produjo en Granada y cuyo relato he querido dejar para el final. Resultó que Antonio MesA-Moles, el interlocutor de KELSEN en Granada y quien como sabemos intercedió en su nombre ante la Universidad de Salamanca para reclamar el título de doctor bonoris causa, conocía a KELSEN mucho antes de ese encuentro. Había sido alumno suyo 22 años atrás. MESA-MOLES era catedrático de Derecho Administrativo y en 1932 fue pensionado por la Junta de Ampliación de Estudios para formarse durante once meses en derecho público en la universidad de Colonia bajo la dirección de KELSEN, donde participó como invitado en su seminario sobre «Problemas fundamentales de Derecho Constitucional» ${ }^{125}$. Quién sabe si KELSEN se acordaba de él y vio entonces servida la ocasión para consultarle acerca del inconcluso asunto de Salamanca. Dado que MeSA-Moles era Secretario General de la Universidad y Decano de la Facultad de Derecho, todo quedaría en un discreto trámite interno académico, casi administrativo, lejos de cualquier intervención de trascendencia política que resultase comprometedora. Y un trámite zanjado rápidamente, puesto que la visita de KeLSEN fue como sabemos muy breve. Acaso todo esto propició el resorte psicológico que indujo en él la apariencia de una neutralidad que en los hechos era imposible.

124 «Después de que finalice el periodo de condominium y su soberanía sea restaurada, Alemania sería jurídicamente un nuevo Estado. No existiría ninguna continuidad entre el destruido Estado nazi y la nueva Alemania democrática. La nueva constitución de la Alemania soberana no sería el resultado de un cambio constitucional o revolucionario en la constitución nazi, sino el comienzo de una nueva vida constitucional. Sólo como una nueva comunidad que no está conectada por vínculo jurídico alguno con la Alemania nazi, entraría la Alemania democrática en la futura organización internacional después de esta guerra» (KELSEN, 1944b: 693, subrayado original). Por cierto que esta posición acerca de la solución de continuidad del Reich le costó a KELSEN el rechazo de sus antiguos colegas constitucionalistas alemanes, quienes dejaron de considerarlo un miembro de su «comunidad moral» (cfr. MüLLER, 2011: 290-291).

125 Obtengo estos datos de PETIT (2014). Ahí figura también que durante la guerra (entre 1937 y 1938) fue secretario local de FET y de las JONS. En su certificado de depuración del Ministerio de Educación Nacional consta que «se le considera persona muy afecta al Glorioso Movimiento Nacional» (5 de julio de 1941). Vid. también PELÁEZ, 1995: 24, 56. Este último autor señala en otro sitio: «Resulta curioso, y ha sido repetido en varias ocasiones, que al único español que recordaba y reconocía Hans KELSEN no era otro que al administrativista granadino Antonio MeSA-Moles SEgURA (1911-1986). ¿Qué debió ver KelSEN en don Antonio, en lo que no se fijaron otros?» (PELÁEZ, 2011: 728). 
464

Jesús Vega

En fin: tal vez todo fue mucho más simple y la razón última debamos encontrarla en la regla del verso final del célebre poema crepuscular que KELSEN tituló — reveladoramente-Carpe diem y que vio la luz en las páginas de esta misma revista (SCHMILL, 1996):

Nur was du ergreifst ist dein!

O sea: «iSolamente aquello que haces tuyo te pertenece!».

Bâle, suiser

le 30 jimited 1956

Monsien Mannal Garcia Blanco

secuitaire Gineiral de l'thiversite' de Valamanca

Salamanca, Espague

Mousiens he fecrétaine General:

than ami, he profersan Anhomio hesa-tholes m'a informo' que vons anuz la grande obligeance de m'emeager, à l'antomme prochain, he diphome consersont he Doctorat "Thomoris Cansa "que l'tminusile' de Salamauca m'a conféré.

Teumettey-mai de vens indiquer mon adreose précioe: 2126 das Angeles Aremue,

Berkeley (pies de San Franciaco), Califonire, U.S.A.

I. saisis cet accasion pans exprimer encose. ne fois ma sincère gratich de pour he grand houneur axce lequel l'mue des phus anciemus el plus celiberes himensities du monde sn'a distingue'.

Venillez agéée, housieur he fecritaire Gineial, l'espression der mes sentrments ber fhus siviceses.

Hanoseremen 


\section{BIBLIOGRAFÍA}

AlarCón, V., 2012: «Hans Kelsen: bitácora de un itinerante» [1989], en G. A. RAmírez, (ed.), Ecos de Kelsen. Vida, obra y controversias, Bogotá: Universidad Externado de Colombia, 35-47.

Arangio-Ruiz, G.; Jiménez de Arechaga, E., y Schachter, O., 1998: «The European Tradition in International Law: Hans Kelsen. Personal Recollections», European Journal of International Law, 9/2: 386-390.

AtienZA, M.: «La Filosofía del Derecho en los países de habla española», inédito.

- 1984: La filosofía del derecho argentina actual, Buenos Aires: Depalma.

Bergmann, G., y Zerby, L., 1945: «The Formalism in Kelsen's Pure Theory of Law», Ethics, 55/2: 110-130.

Berman, H. J., 1955: «Review of The Communist Theory of Law, by Hans Kelsen», University of Pennsylvania Law Review, 104/3: 444-446.

BernstorfF, J. von, y DunLaP, Th., 2010: The Public International Law Theory of Hans Kelsen. Believing in Universal Law, Cambridge, Mass.: CUP.

Delgado Pinto, J., 2002: «Breves notas sobre la evolución de la filosofía del Derecho española entre 1960 y 1984», en V. ZAPATERO (ed.), Horizontes de la Filosofía del Derecho. Homenaje a Luis García San Miguel, s. 1., Servicio de Publicaciones de la Universidad de Alcalá, vol. 2, 103-114.

DíAZ, E., 2009a: «Joaquín Ruiz-Giménez: del derecho natural a los derechos naturales», Doxa, 32: $15-36$.

- 2009b: De la Institución a la Constitución. Política y cultura en la España del siglo XX, Madrid: Trotta.

Ehs, T., y Gassner, M., 2015: «Hans Kelsen (1881-1973). Legal Scholar between Europe and the Americas», Transatlantic Perspectives, disponible en http://www.transatlanticperspectives.org/entry.php? rec $=132$ [fecha consulta 2 de marzo de 2015].

EsCudero, R., y PÉREZ, C. (eds.), 2013: Desapariciones forzadas, represión politica y crímenes del franquismo, Madrid: Trotta.

Feichtinger, J., 2009: «Transatlantische Vernetzungen. Der Weg Hans Kelsens und seines Kreises in die Emigration», en R. WALTER, W. OgRIS y Th. OleCHOwSKI (eds.), Hans Kelsen: Leben - Werk - Wirksamkeit. Ergebnisse einer Internationalen Tagung, veranstaltet von der Kommission für Rechtsgeschichte Österreichs und dem Hans Kelsen-Institut (Schriftenreibe des Hans Kelsen-Instituts, Band 32), Wien: Manzsche Verlags- und Universitätsbuchhandlung, 2009, 321-338.

FinCH, G. A., 1956: «L'Institut de Droit International at Granada», The American Journal of International Law, 50/3: 640-647.

Fuller, L. L., 1954: «American Legal Philosophy at Mid-Century», Journal of Legal Education, 6: 457-485.

FuENTES LABRADOR, A., et al., 1991: «Apoyo institucional en un centro de poder: la Universidad de Salamanca durante la Guerra Civil. Un modelo de comportamiento», en J. J. CARRERAS ARES y M. A. RuIZ CARNiCER (eds.), La Universidad española bajo el régimen de Franco, Zaragoza: Institución Fernando el Católico, 257-281.

Flores, I. B., 2014: «Una visita a Hans Kelsen en México», Problema. Anuario de Filosofía y Teoría del Derecho, 8: 53-94.

García MANRique, R., 1996: La filosofía de los derechos bumanos durante el franquismo, Madrid: CEC. 
— y RivayA, B., 1998: «Cronología comparada de la filosofía del derecho española durante el franquismo (1939-1975)», Anuario de Filosofía del Derecho, 15: 305-334.

García-Salmones, M., 2013: The Project of Positivism in International Law, Oxford: Oxford UP.

Gil Cremades, J. J., 1968: «Estudio preliminar» a ENGISCH, K., La idea de concreción en el Derecho y en la ciencia jurídica actuales, Pamplona: EUNSA, 9-67.

Halbach Jr., E. C., 1973: «Hans Kelsen (1881-1973)», California Law Review, 61/4: 957 960.

Hershberg, J. G., 1993: James B. Conant: Harvard to Hiroshima and the Making of the Nuclear Age, New York: Alfred A. Knopf.

HiERRO, L., 1997: «Nota demasiado breve sobre lo que la Filosofía del Derecho española debe al Prof. Ruiz Giménez», en VVAA, La fuerza del diálogo. Homenaje a Joaquín Ruiz-Giménez, Madrid: Alianza, 113-122.

- 2010: «En Memoria (académica) de Joaquín Ruiz Giménez», Revista de Hispanismo Filosófico, 15: 221-225.

INFANTE Miguel-MotTA, J., 2015: «Salamanca, 7-8 de mayo de 1954: fastos para un dictador (cuatro por el precio de uno)», Artículos del Departamento de Historia del Derecho y Filosofía Jurídica, Moral y política, http://hdl.handle.net/10366/121955 [fecha consulta 1 de febrero de 2015].

Jestaedt, M. (ed.), 2006: Hans Kelsen im Selbstzeugnis. Sonderpublikation anlässlich des 125. Geburtstages von Hans Kelsen am 11. Oktober 2006, en col. con el Hans Kelsen-Institut, Tübingen: Mohr Siebeck.

— 2008: «Estudio Preliminar», en H. Kelsen, Autobiografía, op. cit., 19-50.

Jones, B. Z., 1984: «To the Rescue of the Learned: The Asylum Fellowship Plan at Harvard, 1938-1940», Harvard Library Bulletin, XXXII/3: 205-238.

Juliá, S., 1999: Un siglo de España. Política y sociedad, Madrid: Marcial Pons.

- 2002: «¿Falange liberal o intelectuales fascistas?», Claves de Razón Práctica, 121: 4-13.

Kelsen, H., 1920a: Das Problem der Souveränität und die Theorie des Völkerrechtes. Beitrag zu einer reinen Rechtslebre, Tübingen: Mohr.

- 1920b: Sozialismus und Staat. Eine Untersuchung der politischen Theorie des Marxismus, Leipzig: C. L. Hirschfeld;

- 1923: «Die politische Theorie des Sozialismus», Österreichische Rundschau, 19: 113-135.

- 1924: Marx oder Lasalle. Wandlungen in der polistischen Theorie des Marxismus, Leipzig: C. L. Hirschfeld.

- 1927: «Die Gleichheit vor dem Gesetz im Sinne des Art. 109 der Reichsverfassung», Veröffentlichungen der Vereinigung der Deutschen Staatsrechtslebrer, 3: 2-62.

- 1928: Compendio esquemático de una teoría general del Estado, trad. de L. RECASÉNS y J. DE AzCÁRATE, Barcelona: Florez Núnez y comp., prólogo de L. RECASÉnS.

- 1929: Vom Wesen und Wert der Democratie [1920], Tübingen: Mohr (2.a ed.).

— 1931: «Allgemeine Rechtslehre im Lichte materialistischer Geschichtsauffassung», Archiv für Sozialwissenschaft und Sozialpolitik, 66: 449-521.

- 1933: La Teoría pura del Derecho. Método y conceptos fundamentales, trad. de L. LEGAz, Madrid: Ed. Revista de D. Privado.

- 1934: Teoría general del Estado, trad. de L. LEgAz, Barcelona: Labor.

- 1935a: Esencia y valor de la democracia, trad. de L. LEGAZ, Barcelona: Labor.

- 1935b: The Legal Process and International Order, Londres: Constable \& Co.

- 1938: Zur Reform des Völkerbundes, Praga: Pax Edition. 
- 1939: Legal Technique in International Law. A Textual Critique of the League Covenant, Ginebra: Centro de Investigación de Ginebra (Geneva Studies, X, núm. 6).

- 1941a: «The Pure Theory of Law and Analytical Jurisprudence», Harvard Law Review, 55/1: 44-70.

- 1941b: «The Law as a Specific Social Technique», The University of Chicago Law Review, 9/1: 75-97.

- 1942: Law and Peace in International Relations, Cambridge: Harvard UP.

- 1944a: Peace through Law, Chapel Hill: The University of North Carolina Press.

- 1944b: «The International Legal Status of Germany to be Established Immediately Upon Termination of the War», American Journal of International Law, 38/4: 689-69.

- 1945a: «Sanctions in International Law Under the Charter of the United Nations», Iowa law Review, 31: 499-543.

- 1945b: «The Rule Against expost facto Laws and the Prosecution of the Axis War Criminal», The Judge Advocate Journal, 8: 8-12.

- 1945c: General Theory of Law and State, Cambridge: Harvard UP.

- 1948: The Political Theory of Bolshevism: A Critical Analysis, Berkeley: U. of California Press.

- 1950: The Law of the United Nations. A Critical Analysis of Its Fundamental Problems, London: Stevens \& Sons; New York: Frederick A. Praeger Inc.

- 1952: Principles of International Law, New York: Rinehart \& Co.

- 1955a: The Communist Theory of Law, New York: Frederick A. Praeger Inc.

— 1955b: «The Foundations of Democracy», Ethics, 64: 1-101.

- 1957: What is Justice? Justice, Law and Politics in the Mirror of Science. Collected Essays, Berkeley and Los Angeles: University of California Press.

- 1960: «Recht und Moral», en Estudios jurídico-sociales. Homenaje al Profesor Luis LEGAZ y Lacambra, Santiago de Compostela: U. de Santiago de Compostela, vol. I, 153-164.

- 2007: Hans Kelsen Werke. Band 1: Veröffentlichte Schriften 1905-1910 und Selbstzengnisse, ed. de M. JestaedT en col. con el Hans Kelsen-Institut, Tübingen: Mohr Siebeck.

- 2008: Autobiografía, trad. de L. Villar BORDA, Bogotá: Universidad Externado de Colombia.

- 2012: Secular Religion: A Polemic against the Misinterpretation of Modern Social Philosophy, Science and Politics as «New Religions» [1964], Wien: Springer.

Kennedy, D., 1995: «Kelsen als Pragmatist des Völkerrechts. Die Oliver Wendell Holmes Lectures des Jahres 1941», en A. CARRINO y G. WINKLER (eds.), Rechtserfahrung und Reine Rechtslebre, Wien: Springer, 95-128.

Ladavac, N. B., 1998: «Hans Kelsen (1881-1973) Biographical Note and Bibliography», European Journal of International Law, 9: 391-400.

LEgAZ, L., 1933: Kelsen: estudio crítico de la Teoría pura del Derecho y del Estado de la Escuela de Viena, prólogo de L. RECASÉns, Barcelona: Bosch.

- 1942: «Notas sobre el valor actual de la Teoría pura del Derecho», Revista General de Legislación y Jurisprudencia, 4: 355-377.

- 1947: «La Teoría pura del Derecho y el pensamiento político de José Antonio Primo de Rivera», en id., Horizontes del pensamiento jurídico (Estudios de Filosofía del Derecho), Barcelona: Bosch, 297-309.

- 1951: «El Estado de Derecho», Revista de Administración Pública, 6: 13-34.

- 1957: «La influencia de la doctrina de Kelsen en la ciencia jurídica española», Revista de Estudios Políticos, 96: 29-40.

— 1972: «Kelsen hoy», Anuario de Filosofía del Derecho, 16: 77-92. 
LÓpez García, J. A., 1996: Estado y Derecho en el franquismo. El nacionalsindicalismo: F. J. Conde y L. Legaz Lacambra, Madrid: CEC.

Losano, M. G., 1989: «Kelsen y Freud» [1977], en O. Correas (ed.), El otro Kelsen, México: UNAM, 99-110.

— 2006: «Hans Kelsen. Una biografía cultural mínima», Derechos y libertades, 14: 113-128.

- 2011: «Gli anni americani di Hans Kelsen», Materiali per una storia della cultura giuridica, XLI: $253-258$.

Martínez NeIRA, M., 2004: «La Facultad de Derecho de Salamanca en la posguerra», en E. Torijano, S. DE Dios y J. Infante (eds.), El Derecho y los juristas en Salamanca (siglos XVI-XX). En memoria de Francisco Tomás y Valiente, Salamanca: Ediciones Universidad de Salamanca-CajaDuero, 148-207.

MESA, R. (ed.), 1982: Jaraneros y alborotadores. Documentos sobre los sucesos estudiantiles de febrero de 1956 en la Universidad Complutense de Madrid, Madrid: Editorial de la Universidad Complutense.

MÉTALl, R. A., 1976: Hans Kelsen. Vida y obra [1969], trad. de J. Esquivel, México: UNAM, Instituto de Investigaciones Jurídicas.

Moradiellos, E., 2000: La España de Franco (1939-1975). Política y sociedad, Madrid: Síntesis.

MorÁn, G., 1988: El maestro en el erial. Ortega y Gasset y la cultura del franquismo, Barcelona: Tusquets.

MülleR, I., 2011: Los juristas del horror [1987], trad. de C. A. FigueREdO, Bogotá: Inv. Rosa Mística.

MuÑOz Soro, J., 2006: «Joaquín Ruiz-Giménez o el católico total (apuntes para una biografía política e intelectual hasta 1963)», Pasado y Memoria. Revista de Historia Contemporánea, 5: 259-288.

NitsCH, C., 2009: «"Holmes Lectures, 1940-41”. Studio storico-critico su Kelsen in America», en H. KELSEN, Diritto e pace nelle relazione internazionale. Le Oliver Wendell Holmes lectures, 1940-41, Milano: Giuffrè, III-LXX.

OLECHOWSKI, Th., 2009: «Der Beitrag Hans Kelsens zur österreichische Bundesverfassung», en R. WALTER et al. (eds.), Hans Kelsen: Leben - Werk - Wirksamkeit, op. cit., 211-230.

- 2011: «Biographische Untersuchungen zu Hans Kelsen», Rechtsgeschichtliche Vorträge, 64: $3-22$.

ORTEGA y GASSET, J., 1965: La idea de principio en Leibniz y la evolución de la teoría deductiva [1948], en Obras Completas, Madrid: Revista de Occidente, 2. ${ }^{a}$ ed., vol. VIII, 59-356.

PAulson, S. L., 1988: «Die Rezeption Kelsens in Amerika», en O. WeInBERGER y W. KRAWIETZ (eds.), Reine Rechtslebre im Spiegel ibrer Fortsetzer und Kritiker, Viena: Springer, 179-202.

- 2000: «On Hans Kelsen's Role in the Formation of the Austrian Constitution and his Defense of Constitutional Review», en W. KRAWIETZ et al. (eds.), The Reasonable as Rational? On Legal Argumentation and Justification. Festschrift for Aulis Aarnio, Berlin: Duncker \& Humblot, 385-395.

PeLÁEZ, M. J., 1995: Infrahistorias e intrahistorias del derecho español del siglo XX. Un paisaje jurídico con treinta figuras, Málaga: Universidad de Málaga.

— 2011: «Sección Bibliografía», Revista de Estudios Histórico-Jurídicos, XXXIII.

PetiT, C., 2014: «Mesa-Moles Segura, Antonio (1911-1986)», en Diccionario de Catedráticos Españoles de Derecho 1847-1943, disponible en bttp://portal.uc3m.es [fecha de consulta 12 de enero de 2015].

Pound, R., 1934: «Law and the Science of Law in Recent Theories», Yale Law Journal, 43/4: 525-536. 
PÉrez Delgado, T., 2006: «Conmemoraciones del VII Centenario: política y discurso», en L. E. Rodríguez (ed.), Historia de la Universidad de Salamanca, Salamanca: Eds. Universidad de Salamanca, vol. III-2, Saberes y confluencias, 1353-1377.

PRESTON, P., 1994: Franco «Caudillo de España», Barcelona: Grijalbo-Mondadori, 5. a ed.

RathKolb, O., 2009: «Hans Kelsen und das FBI während des McCarthysmus in den USA», en R. WALter et al. (eds.), Hans Kelsen: Leben - Werk - Wirksamkeit, op. cit., 339-348.

ReCAsÉns, L., 1974; «Balance de la Teoría Pura del Derecho de Kelsen», Boletín Mexicano de Derecho Comparado, 19: 165-177.

RIVAYA, B., 1996: «La filosofía jurídica en los comienzos del Nuevo Estado español», Sistema, 131: 87-103.

- 1998: Filosofía del Derecho y primer franquismo (1937-1945), Madrid: CEC.

- 2000: «Kelsen en España», Revista de Estudios Políticos, 107: 151-177.

- 2010: Una bistoria de la Filosofía del Derecho española del siglo XX, Madrid: Iustel.

RoBles, G., 1982: «La recepción de Kelsen en la cultura jurídica española», en id., Epistemología y Derecho, Madrid: Pirámide, 151-197.

- 2014: Hans Kelsen. Vida y obra, Madrid: Civitas.

Rodilla, M. A., 2002: «Entrevista a José Delgado Pinto», Doxa, 25: 737-762.

RodrígueZ DE LECEA, T., 2013: «Introducción» a J. RuIZ-GiménEZ Cortés, Diarios de una vida. 1967-1978, Madrid: Cortes Generales-Defensor del Pueblo, 17-39.

RODRÍGUEZ LÓPEZ, C., 2008: «Extirpar de raíz: la depuración del personal docente universitario durante el franquismo. Los catedráticos de las facultades de Derecho», en F. FERNÁNDEZCrehuet López y A. M. HesPanha (eds.), Franquismus und Salazarismus: Legitimation durch Diktatur? (Das Europa der Diktatur, 15), Frankfurt am Main: Klostermann, 61-99.

Ruiz Manero, J., 1986: «Sobre la crítica del Kelsen al marxismo», Doxa, 3: 191-232.

- 1988: «Teoría de la democracia y crítica del marxismo en Kelsen», en H. KeLSEN, Escritos sobre la democracia y el socialismo, Madrid: Debate, 11-61.

SARLO, O., 2010: «La gira sudamericana de Hans Kelsen en 1949. El "frente sur" de la teoría pura», Ambiente Jurídico, 12: 401-426.

Saz Campos, I., 2013: Las caras del franquismo, Granada: Comares.

SCHMILl, U., 1996: «Un poema de Kelsen», Doxa, 19: 33-36.

Sosa Wagner, F., 2002: Maestros alemanes del Derecho público (I), Madrid: Marcial Pons.

- 2004: Maestros alemanes del Derecho público (II), Madrid: Marcial Pons.

- 2009: Juristas en la Segunda República. 1. Los iuspublicistas, Madrid: Marcial Pons.

ScHAmBECK, H., 2013: «Hans Kelsen Leben und Werk. Gedanken su seinem 40. Todestag», The Lawyer Quarterly. International Journal for Legal Research, 3/4: 265-282.

SCHÄTZEL, W., 1956: «Tagung des Institut de Droit International in Granada 1956», Archiv des Völkerrechts, 6/1: 61-63.

Summers, R. S., 1984: Lon L. Fuller, Stanford: Stanford UP.

Telman, J., 2008: «The Reception of Hans Kelsen's Legal Theory in the United States: A Sociological Model», L'Observateur des Nations Unis, 24: 1-25.

— 2010: «A Path Not Taken: Hans Kelsen's Pure Theory of Law in the Land of the Legal Realists», en R. WALter, C., JABLONER y K. Zeleny (eds.), Hans Kelsen anderswo/Hans Kelsen abroad. Der Einfluss der Reinen Rechtslebre auf die Rechtstheorie in verschiedenen Ländern, Teil III (Schriftenreibe des Hans Kelsen-Instituts, Band 33), Wien: Manzsche Verlags- und Universitätsbuchhandlung, 353-376.

- 2011: «Law or Politics? Hans Kelsen and the Post-War International Order», Constellations, 18: 513-528. 
Verdross, A., 1948: Grundlinien der antiken Rechts- und Staatsphilosophie, Viena: Springer (2. ${ }^{\mathrm{a}}$ ed.).

- 1955: Völkerrecht, Viena: Springer, 3. ${ }^{a}$ ed.

- 1971: «Der Beitrag der christlichen Naturrechtslehre zum Primat des Völkerrechts», en A. MERKL et al. (eds.), Festschrift für Hans Kelsen zum 90. Geburtstag, Viena: F. Deuticke, 276-284.

VVAA, 2011: Guzmán Gombau fotografía el VII Centenario de la Universidad de Salamanca (1953-1954). Liberalización cultural y apertura internacional de la universidad franquista, Salamanca: Ediciones Universidad de Salamanca, s. d. [2011]. 